\title{
ESTUDOS FISIOLÓGICOS E TECNOLÓGICOS DE COUVE-FLOR E RÚCULA MINIMAMENTE PROCESSADAS
}

\section{JOSÉ MARIA MONTEIRO SIGRIST}

Engenheiro Agrônomo

Tese apresentada à Escola Superior de Agricultura

"Luiz de Queiroz", Universidade de São Paulo, para obtenção do título de Doutor em Agronomia, Área de Concentração: Fitotecnia.

P I R A C I C A B A

Estado de São Paulo - Brasil

Novembro - 2002 


\title{
ESTUDOS FISIOLÓGICOS E TECNOLÓGICOS DE COUVE-FLOR E RÚCULA MINIMAMENTE PROCESSADAS
}

\author{
JOSÉ MARIA MONTEIRO SIGRIST
}

Engenheiro Agrônomo

Orientador: Prof. Dr. KEIGO MINAMI

Tese apresentada à Escola Superior de Agricultura “Luiz de Queiroz", Universidade de São Paulo, para obtenção do título de Doutor em Agronomia, Área de Concentração: Fitotecnia.

P I R A C I C A B A

Estado de São Paulo - Brasil

Novembro - 2002 


\section{Dados Internacionais de Catalogação na Publicação (CIP)}

DIVISÃO DE BIBLIOTECA E DOCUMENTAÇÃO - ESALQ/USP

Sigrist, J osé Maria Monteiro

Estudos fisiológic os e tecnológicos de couve-flor e rúcula minima mente processa das / J osé Maria Monteiro Sigrist. - - Piracic aba, 2002.

$112 \mathrm{p}$.

Tese (doutorado) - Escola Superior de Agricultura Luiz de Queiroz, 2002. Bibliografia.

1. Couve-flor - Qualidade 2. Efeito da temperatura 3. Fisiologia pós-colheita 4. Meta-bolismo vegetal 5. Processamento de alimentos 6. Respiração vegetal 7. Rúcula - Qualidade I. Título

CDD 635.35

"Permitida a cópia total ou parcial deste documento, desde que citada a fonte - $\mathrm{O}$ autor" 
Aos meus pais José (in memoriam) e Ruth, pelos ensinamentos, amor, dedicação e, sobretudo, exemplo de vida...; À minha irmã Maria José, pelo constante apoio, incentivo e compreensão, 


\section{AGRADECIMENTOS}

A Deus, por tudo... Iluminando-me sempre e, principalmente, agora, para que eu pudesse vencer mais esta etapa.

Ao Centro de Pesquisa e Desenvolvimento de Hortifrutícolas (FRUTHOTEC), do Instituto de Tecnologia de Alimentos (ITAL), por permitir minha participação neste Curso.

Ao Conselho Nacional de Desenvolvimento Científico e Tecnológico (CNPq), pela bolsa concedida durante parte da realização deste Curso.

Ao Prof. Dr. Keigo Minami, pela orientação, amizade, apoio e confiança em mim e em meu trabalho.

Ao Prof. Dr. Durval Dourado Neto, pela amizade e constante apoio nos momentos difíceis.

À Pesquisadora Científica Claire I. G. L. Sarantópoulos, do Centro de Tecnologia de Embalagem (CETEA/ITAL), pela amizade, incentivo e participação ativa nos experimentos de embalagem deste trabalho.

À Pesquisadora Científica Neliane Ferraz de Arruda Silveira e à bióloga Elizabeth Bragion Prestes, do Laboratório de Microbiologia do ITAL, pela realização das análises microbiológicas.

À amiga de todas as horas, Dra. Eliane Aparecida Benato Rodrigues da Silva, por sua participação nas avaliações sensoriais.

À Dra. Fagoni Fayer Calegário e ao Eng ${ }^{\circ}$ Agr $^{\circ}$ Carlos Susumu Nakajima, pela amizade e inestimável auxílio em várias etapas da execução deste trabalho. 
Aos Eng $^{\text {os }}$ Agr $^{\text {os }}$ Cibele Binotti Nucci e Laurent Jacques Berthier e aos bolsistas de Iniciação Científica, Stefan Adriaan Copelmans e Thyago Moreira, pelas indispensáveis colaborações nas montagens dos experimentos e avaliações sensoriais.

Aos Eng $^{\text {os }}$ Agr $^{\text {os }}$ Patrícia Cia, Silvia Valentini, Victor Ricardo de Souza Muñoz e Eng $^{\circ}$ Agrícola Wigberto Antonio Spagnol, pelas avaliações sensoriais das hortaliças minimamente processadas.

À técnica de laboratório do FRUTHOTEC/ITAL, Débora Belo Alves, à Auxiliar de Apoio à Pesquisa Quitéria Maria Alves de Oliveira e aos estagiários Ana Carolina de Paiva, Camila Cremonesi, Cristiana Ferraz de Siqueira, Fátima Graziela Guimarães e Roberta Engels do Nascimento, pelo auxílio na realização das análises químicas e sensoriais.

Aos professores do Departamento de Produção Vegetal, pelos conhecimentos transmitidos e a seus funcionários, especialmente, Bete, Célia, Ivete, D. Helena e Luciane, pela atenção, apoio e pronto atendimento às minhas solicitações.

À Prof ${ }^{a} \operatorname{Dr}^{\mathrm{a}}$ Hilary Castle de Menezes, pela revisão dos textos em inglês e Srta. Vera Luporini, pela revisão de português.

À Sra. Lurdes F. Gandra, pelo auxílio na formatação desta tese e à Bibliotecária Silvia Zinsly, pelas sugestões, correções e revisão desta formatação.

Aos colegas do Curso de Pós-Graduação, pela agradável convivência e amizade. 


\section{SUMÁRIO}

\begin{tabular}{|c|c|}
\hline & \\
\hline RES & MO ............ \\
\hline SUN & IARY \\
\hline $1 \mathrm{II}$ & RODUÇÃO ....... \\
\hline $2 \mathrm{R}$ & ISÃO DE LITERATURA .. \\
\hline 2.1 & 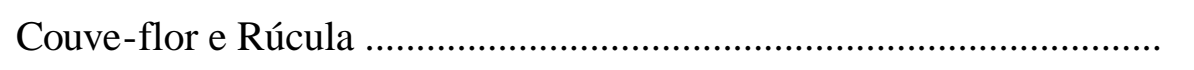 \\
\hline & 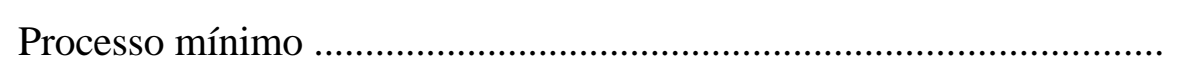 \\
\hline
\end{tabular}

2.2.1. Fatores que influenciam a qualidade de produtos processados

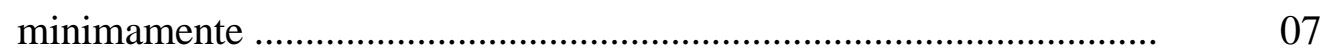

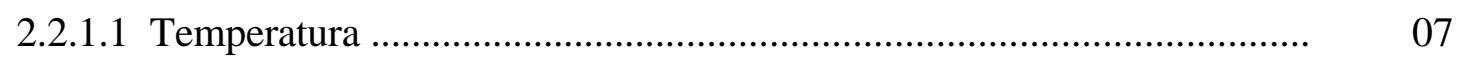

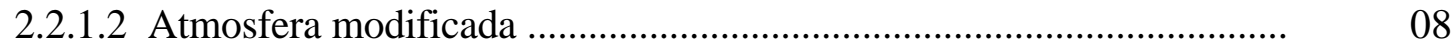

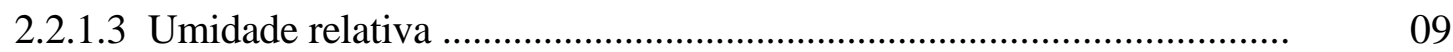

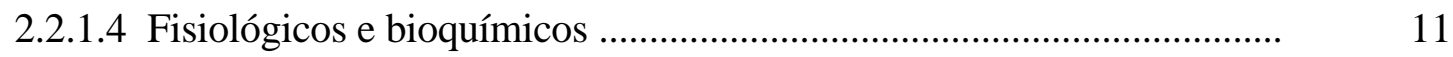

2.2.1.5 Microrganismos .............................................................................

3 EFEITO DA TEMPERATURA NOS METABOLISMOS DE COUVEFLOR E RÚCULA INTEIRAS E MINIMAMENTE PROCESSADAS ....... 14

Resumo ............................................................................................

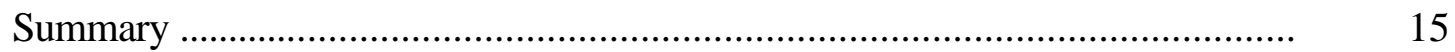

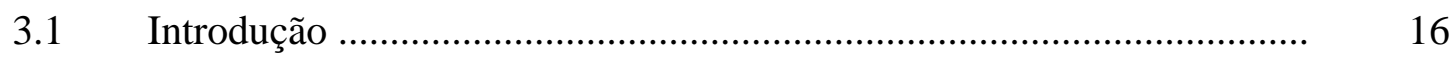

3.2 Materiais e métodos ............................................................................... 18

3.3 Resultados e discussão ...................................................................... 21

3.3.1 Taxas respiratórias de couves-flores e floretes ........................................ 21

3.3.2 $\mathrm{Q}_{10}$ para couve-flor e floretes ............................................................ 24

3.3.3 Taxas respiratórias de rúculas e de folhas de rúculas ............................. 25 
3.3.4 Q Q para rúculas e folhas de rúculas ........................................................ 27

3.3.5 Produção de etileno ................................................................................... 29

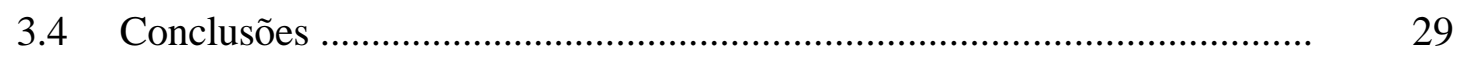

4 INFLUÊNCIA DE EMBALAGENS COM FILMES FLEXÍVEIS NA QUALIDADE DE FLORETES DE COUVES-FLORES ............................. 30

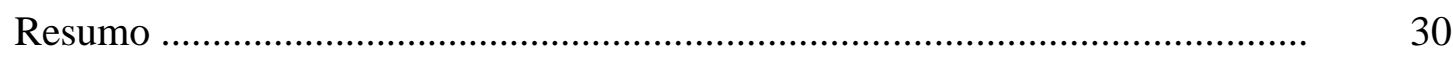

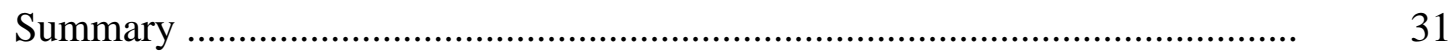

4.1 Introdução ..................................................................................

4.2 Materiais e métodos .............................................................................

4.3 Resultados e discussão …………………………………………….....

4.3.1 Composição gasosa no interior das embalagens .......................................

4.3.2 pH e acidez titulável ........................................................................

4.3.3 Sólidos solúveis $\left({ }^{\circ} \mathrm{Brix}\right)$.......................................................................

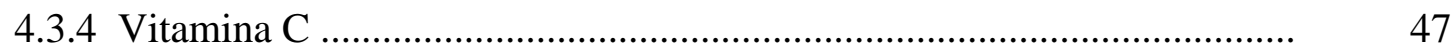

4.3.5 Coloração dos floretes .......................................................................... 49

4.3.6 Firmeza ………......................................................................

4.3.7 Análises microbiológicas ..................................................................

4.3.8 Análise sensorial .......................................................................... 56

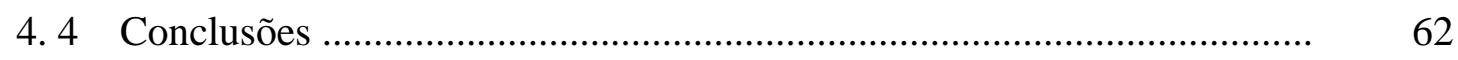

5 INFLUÊNCIA DE EMBALAGENS COM FILMES FLEXÍVEIS NA QUALIDADE DE RÚCULA MINIMAMENTE PROCESSADA ................. 64

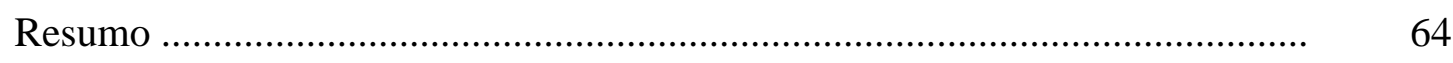

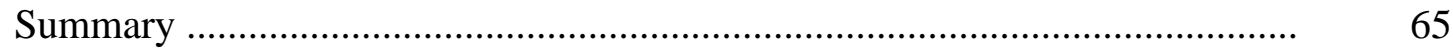

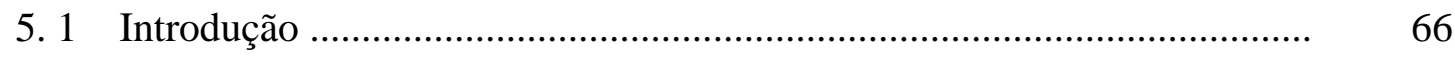

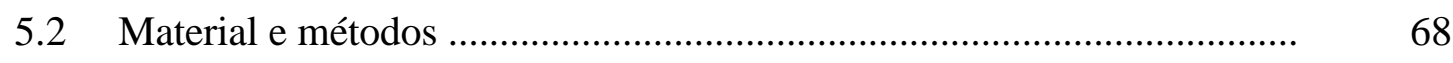

5.3 Resultados e discussão ..........................................................................

5.3.1 Composição gasosa no interior das embalagens .......................................

$5.3 .2 \mathrm{pH}$ e acidez titulável .......................................................................

5.3.3 Sólidos solúveis ................................................................................

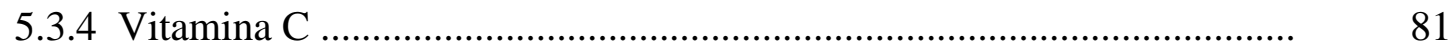


5.3.5 Coloração ………………………………………………………….....

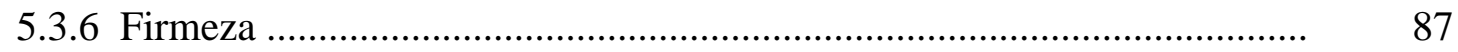

5.3.7 Análises microbiológicas .....................................................................

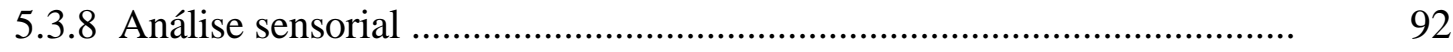

5.4 Conclusões ................................................................................... 96

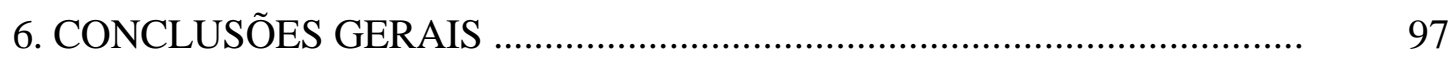

REFERÊNCIAS BIBLIOGRÁFICAS _............................................................... 98 


\title{
ESTUDOS FISIOLÓGICOS E TECNOLÓGICOS DE COUVE-FLOR E RÚCULA MINIMAMENTE PROCESSADAS
}

\author{
Autor: JOSÉ MARIA MONTEIRO SIGRIST \\ Orientador: Prof. Dr. KEIGO MINAMI
}

\section{RESUMO}

Este trabalho teve por finalidade avaliar os efeitos de temperatura nos metabolismos de couves-flores e rúculas inteiras e minimamente processadas e diferentes materiais de embalagem na sua qualidade. No primeiro experimento, couvesflores, seus floretes, rúculas e suas folhas foram mantidos a $1^{\circ}, 5^{\circ}$ e $11^{\circ} \mathrm{C}$ e determinados suas taxas de respiração, produção de etileno e quocientes de temperatura $\left(\mathrm{Q}_{10}\right)$. No segundo, os floretes foram colocados em embalagens de filmes de polietileno de baixa densidade (PEBD), poliolefínicos coextrusados (PD - 941 e Clysar) e de policloreto de vinila, PVC esticável de 12 e $20 \mu \mathrm{m}$, envolvendo bandejas de poliestireno expandido mantidos a $5^{\circ} \mathrm{C}$. Análises físicas, químicas, físico-químicas, microbiológicas e sensoriais foram realizadas. No terceiro, folhas de rúculas foram colocadas em embalagens de filme de polietileno de baixa densidade (PEBD), laminado de polipropileno/polietileno (PP/PE), poliolefínicos coextrusados (PD - 900 e Clysar) e de policloreto de vinila, PVC esticável de $20 \mu \mathrm{m}$, envolvendo bandejas de poliestireno expandido e armazenados a $5^{\circ} \mathrm{C}$. Análises físicas, químicas, físico-químicas, microbiológicas e sensoriais foram realizadas. As taxas respiratórias das couves-flores inteiras e minimamente processadas foram iguais em quaisquer das temperaturas estudadas e sempre decrescentes até o $16^{\circ}$ dia. A $1^{\circ}$ e a $5^{\circ} \mathrm{C}$, tiveram a mesma taxa respiratória, diferindo das mantidas a $11^{\circ} \mathrm{C}$. $\mathrm{Na}$ faixa de $1^{\circ}$ a $11^{\circ} \mathrm{C}$, o $\mathrm{Q}_{10}$ foi o mesmo para floretes e couves-flores; 2,1 e 2,2, 
respectivamente. Comportamento distinto tiveram as rúculas inteiras e as folhas soltas, pois, a $1^{\circ} \mathrm{C}$ e a $5^{\circ} \mathrm{C}$, as taxas respiratórias foram significativamente iguais. $\mathrm{A} 11^{\circ} \mathrm{C}$, a partir do $4^{\circ}$ dia, as folhas soltas começaram a apresentar taxas de respiração superiores às das inteiras, chegando a ser o dobro nos $14^{\circ}$ e $16^{\circ}$ dias de armazenamento. $\mathrm{O} \mathrm{Q}_{10}$ médio para as rúculas inteiras situou-se ao redor de 3,54 e para as folhas soltas, 5,74, na faixa de $1^{\circ}$ a $11^{\circ} \mathrm{C}$. Não foi detectada produção de etileno. As embalagens para floretes de couves-flores tiveram pouca ou nenhuma influência em seu $\mathrm{pH}$, acidez, ${ }^{\circ}$ Brix, luminosidade, croma, Hue e firmeza. A embalagem PD - 941 foi a melhor por manter uma atmosfera modificada próxima à da recomendada para couves-flores $\left(2-3 \% \mathrm{O}_{2} \mathrm{e}\right.$ $\mathrm{CO}_{2}<5 \%$ ) e permitir menores perdas de vitamina $\mathrm{C}$ e melhores notas para vários atributos sensoriais de qualidade. Todas as embalagens mantiveram níveis de coliformes totais, bolores e leveduras bem abaixo dos limites permitidos pela Legislação Brasileira. As folhas de rúculas apresentaram níveis de coliformes totais ao redor de $10^{5} \mathrm{UFC} / \mathrm{g}$ de produto no $10^{\circ}$ dia a $5^{\circ} \mathrm{C}$, tornando-as impróprias para o consumo. Nestes 10 dias, as embalagens de PEBD e PP/PE se destacaram em relação às outras por reterem melhor a vitamina $\mathrm{C}$ e a coloração verde das folhas, por alcançarem melhores valores para sólidos solúveis, firmeza, presença de odor estranho, qualidade geral das folhas, deterioração e murchamento. As atmosferas modificadas desenvolvidas no interior destas embalagens, 5 a $7 \% \mathrm{O}_{2}$ e 10 a $15 \% \mathrm{CO}_{2}$, talvez sejam as mais indicadas para a conservação de rúculas minimamente processadas a $5^{\circ} \mathrm{C}$. 


\title{
PHYSIOLOGICAL AND TECHNOLOGICAL STUDIES OF FRESH-CUT CAULIFLOWER AND SALAD ROCKET
}

\author{
Author: JOSÉ MARIA MONTEIRO SIGRIST \\ Adviser: Prof. Dr. KEIGO MINAMI
}

\section{SUMMARY}

This work aimed at evaluating the effects of temperature on the metabolism of minimally processed and intact cauliflowers and salad rockets, and of different packaging materials on the quality of cauliflower florets and loose salad rocket minimally processed leaves. In the first experiment, intact cauliflowers, florets, intact salad rockets and loose salad rocket leaves were held at $1^{\circ}, 5^{\circ}$ and $11^{\circ} \mathrm{C}$ and their respiration rates, ethylene production and temperature quotients $\left(\mathrm{Q}_{10}\right)$ determined. In the second experiment, the florets were packed in low density polyethylene film (PEBD), co-extruded polyolefins (PD - 941 and Clysar AFG) and in 12 and $20 \mu \mathrm{m}$ polyvinyl chloride (PVC) overwrapping expanded polystyrene trays, and maintained at $5^{\circ} \mathrm{C} / 85$ 95\% relative humidity for 14 days. In the third experiment, loose salad rocket leaves were held under the same conditions in bags of low density polyethylene film (PEBD), laminated polypropylene/polyethylene film (PP/PE), co-extruded polyolefins, PD - 900 and Clysar HP and in expanded polystyrene trays overwrapped with $20 \mu \mathrm{m}$ polyvinyl chloride (PVC). In the second and third experiments, physical, chemical, physicalchemical, microbiological and sensory analyses were performed. The respiration rates of both intact and fresh-cut cauliflowers declined over the 16-day period and were significantly the same at all temperatures studied. At $1^{\circ}$ and $5^{\circ} \mathrm{C}$ the respiration rates were the same but differed from those (cauliflower and florets) at $11^{\circ} \mathrm{C}$. From $1^{\circ}$ to $11^{\circ} \mathrm{C}$, 
the $\mathrm{Q}_{10}$ for the cauliflowers was 2.2 and for the florets, 2.1. In contrast, the intact and fresh-cut salad rocket respiration rates were the same at $1^{\circ}$ and $5^{\circ} \mathrm{C}$. At $11^{\circ} \mathrm{C}$, the freshcut salad rocket showed higher respiration rates than the intact ones as from the $4^{\text {th }}$ day. By the end of the experiment $\left(14^{\text {th }}\right.$ and $16^{\text {th }}$ days) the respiration rates of the fresh-cut salad rockets were twice those of the intact salad rockets, whose $\mathrm{Q}_{10}$ was about 3.45 from $1^{\circ}$ to $11^{\circ} \mathrm{C}$ as compared to 5.74 for the fresh cut product. No ethylene production was detected by any sample at any temperature. The packaging materials had little or no effect on $\mathrm{pH}$, titratable acidity, soluble solids, luminosity, chroma, hue and firmness of the florets at $5^{\circ} \mathrm{C}$. PD -941 seemed to be the best packaging for florets, maintaining the atmosphere closest to that recommended for intact cauliflower $\left(2-3 \% \mathrm{O}_{2}, \mathrm{CO}_{2}<5 \%\right)$, showing the lowest vitamin $\mathrm{C}$ losses and the best scores for several of the quality attributes. In general, all the packaging materials kept the yeast and mold counts low and the total coliform counts far below the maximum values permitted by the Brazilian Legislation, during 14 days at $5^{\circ} \mathrm{C}$, except for fresh-cut salad rocket leaves, which presented $10^{5} \mathrm{CFU} / \mathrm{g}$ total coliforms by the $10^{\text {th }}$ day, being inappropriate for consumption. For 10 day periods, PEBD and PP/PE were the best packaging materials for green color and vitamin $\mathrm{C}$ retention, higher soluble solids, firmness, lack of offodors, overall quality, decay and shriveling. The modified atmosphere generated inside these packaging materials $\left(5-7 \% \mathrm{O}_{2}, 10-15 \% \mathrm{CO}_{2}\right)$ seemed the best for maintaining the quality of fresh-cut salad rockets held at $5^{\circ} \mathrm{C}$. 


\section{INTRODUÇÃO}

$\mathrm{Na}$ sociedade moderna, os padrões de consumo de alimentos têm mudado em resposta ao estilo de vida, necessidades, gostos, percepção de segurança alimentar, poder de compra dos consumidores e à publicidade veiculada na mídia. A ênfase está em assegurar um adequado suprimento de calorias e nutrientes, qualidade, frescor $\mathrm{e}$ conveniência para serem preparados e servidos. Este fato tem levado a uma crescente popularidade de frutas e hortaliças minimamente preparadas em detrimento destes mesmos produtos, em sua forma original ou processada, como os enlatados ou congelados (Chanes et al., 1997).

Além das vantagens citadas, o processamento mínimo contribui para agregar valor a estes produtos e reduzir a mão-de-obra de seu preparo em restaurantes, hotéis ou lanchonetes e o lixo em áreas metropolitanas (Ohlsson, 1994; Watada et al., 1996). Quando preparados em um único local, o volume de lixo acumulado pode ser facilmente canalizado para outros fins, como a fabricação de ração animal.

Produtos minimamente processados vêm ganhando uma proporção significativa do mercado de frutas e hortaliças in natura, desde a sua introdução nos canais de distribuição dos Estados Unidos, cerca de 30 anos atrás e, na França, no início da década de 80 (Reyes, 1996). De acordo com a Produce Marketing Association (PMA), os Estados Unidos venderam US\$7,9 bilhões de frutas e hortaliças minimamente

processadas, em 1997 e esperam atingir a cifra de US\$19 bilhões, em 2003 (FNP Consultoria \& Comércio, 2000).

No Brasil, embora se observe um crescimento na oferta destes produtos, não se tem conhecimento de estatísticas oficiais. O que existe são projeções isoladas, como a de que, nos grandes centros urbanos, como na Grande São Paulo, houve um crescimento de 
$200 \%$ na oferta destes produtos ou que , em 1998, o Brasil movimentou $\mathrm{R} \$ 450$ milhões de frutas e hortaliças minimamente processadas (FNP Consultoria \& Comércio, 2000).

Porém, através de simples observação, pode-se avaliar o potencial de mercado para estes produtos prontos para o consumo, uma vez que se constata o aumento de espaços para estas hortaliças semiprocessadas, em gôndolas de supermercados de grandes centros urbanos, como também o aumento de lojas de conveniência, especializadas na sua comercialização.

De modo geral, sabe-se que a indústria de "pratos prontos", na região metropolitana de São Paulo, experimentou um crescimento de $148 \%$, no período de 1995 a 1997 (Grinbaum \& Fernandes, 1998). Atribuem este crescimento à mudança de comportamento, onde a mulher, por opção ou necessidade, já representa $49 \%$ das pessoas economicamente ativas na Grande São Paulo.

Desta forma, em supermercados e lojas de conveniência paulistas já é comum encontrar abóbora, abobrinha, agrião, alface, berinjela, brócolos, cebola, cenoura, couve, couve-flor, pimentão, repolho, rúcula, etc ou combinações de alguns destes produtos já cortados, higienizados e embalados, prontos para o consumo.

Apesar desta variedade de produtos, todos eles têm, em comum, um prazo de validade de apenas 4 a 6 dias, considerado como mínimo por Wiley (1994). O desejável, segundo este autor, seria que as frutas e hortaliças minimamente processadas mantivessem sua qualidade por cerca de 21 dias.

Esta curta vida-de-prateleira advém do fato de que, no Brasil, a maioria destes produtos é elaborada de forma bastante empírica ou pelo "conhecimento" de tecnologias de outros países, adquiridas pelos próprios processadores.

Em anos recentes, esta área vem despertando a atenção de vários pesquisadores brasileiros que já possuem, em andamento, estudos com: abacaxi, goiaba, melão, melancia, mamão, manga, cebola, alface, beterraba, couve, repolho, brócolos, batata e batata-doce.

Porém, com as Brassicáceas, como couve-flor e rúcula (de grande importância em São Paulo e outros Estados do Sul do Brasil), pouca ou nenhuma pesquisa vem sendo realizada, em nível nacional ou internacional. 
Assim, o presente estudo teve como objetivo estudar o metabolismo de couvesflores e rúculas minimamente processadas, avaliando-se as respirações e produções de etileno em diferentes temperaturas, quocientes de temperatura $\left(\mathrm{Q}_{10}\right)$ e o efeito de diferentes filmes flexíveis na manutenção de suas qualidades sob refrigeração. 


\section{REVISÃO DE LITERATURA}

\subsection{Couve-flor e rúcula}

A couve-flor é originária da Ásia Menor e foi levada à Europa no século XVI. É uma hortaliça rica em $\mathrm{Ca}, \mathrm{P}$, folato e vitamina $\mathrm{C}$ e tem baixos níveis de $\mathrm{Na}$ (Tavares et al., 2000b).

No Brasil, a couve-flor é mais cultivada nos Estados de São Paulo, Rio de Janeiro, Rio Grande do Sul, Minas Gerais, Paraná e Santa Catarina. No Estado de São Paulo, as principais produções situam-se nas regiões de Sorocaba e Campinas. Com cultivares adaptados às condições mais quentes, pode-se produzir esta hortaliça durante o ano todo (Blanco et al., 1997).

Na Companhia de Entrepostos e Armazéns Gerais de São Paulo (CEAGESP), o volume de entrada de engradados de $8 \mathrm{~kg}$ tem sido de 1.622 .400 (1997), 1.393.617 (1998), 1.345 .766 (1999), 1.250 .108 (2000) e 1.502.249 (2001) (Companhia de Entrepostos e Armazéns Gerais de São Paulo, 2002a).

Quanto à rúcula, ela é uma hortaliça originária da Região Mediterrânea, muito popular nas regiões de colonização italiana no Brasil. É rica em K, S, Fe e vitaminas A e C e é apreciada pelo sabor picante e cheiro agradável e acentuado (Trani \& Passos, 1998).

Em São Paulo, as principais microrregiões produtoras são Paranapiacaba, Grande São Paulo, Sorocaba e Campinas, cabendo às duas primeiras quase $90 \%$ da produção (Trani \& Passos, 1998).

Pelo volume de entrada, expresso em dúzias de maços desta hortaliça na CEAGESP, pode-se verificar como seu consumo vem aumentando a cada ano. Em 1997, 
entraram 139.707 dúzias de maços; em 1998, 190.119; em 1999, 283.252; em 2000, 382.027 e em 2001, 444.730 dúzias de maços (CEAGESP, 2002b).

O aumento no consumo destas hortaliças também tem sido observado em sua forma minimamente processada, como floretes de couves-flores e folhas de rúculas já lavadas, higienizadas e embaladas, prontas para serem consumidas.

\subsection{Processo mínimo}

Muitos são os sinônimos utilizados para o termo "minimamente processados". Pode-se destacar, entre eles, os seguintes: "levemente processadas", "parcialmente processadas", "processadas, porém frescas", "pré-preparadas", "prontas para o uso", “pré-cortadas", “cortadas e frescas”, etc. (Cantwell, 1992)

Embora com vários nomes, o processamento mínimo de frutas e hortaliças refere-se às operações que eliminam as partes não comestíveis como cascas, talos, sementes, raízes, etc., seguidas pelo corte em tamanhos menores, tornando-as prontas para o consumo imediato, sem que elas percam as características de produtos frescos (definição adaptada de Luengo \& Lana, 1997).

No Brasil, as frutas ainda são dificilmente encontradas nesta forma, ao contrário das hortaliças, que hoje são adquiridas em várias opções. Assim, são oferecidos: as cenouras e beterrabas raladas ou em cubos; as couves, alfaces e repolhos picados; os pimentões e vagens cortados; os alhos descascados e cortados; as cebolas, berinjelas, abobrinhas fatiadas; as abóboras em cubos; os feijões-de-corda e milhos-doces debulhados, o agrião, a rúcula em folhas soltas; o brócolos e a couve-flor sem as folhas, com as inflorescências subdivididas em unidades menores, etc. Estas hortaliças minimamente processadas são apresentadas aos consumidores embaladas individualmente ou combinadas em forma de saladas mistas. Muitas destas embalagens contém sachês de molhos realçando sua praticidade.

Este processo mínimo não impede que os tecidos das hortaliças e frutas permaneçam vivos e respirando. 
A operação de corte, por exemplo, causa mudanças fisiológicas associadas a injúrias mecânicas ou ferimentos nos tecidos vegetais, fazendo com que a vida de póscolheita destes produtos seja menor do que a daqueles que lhes deram origem (Rolle \& Chism, 1987). Assim, quanto mais afiados estiverem os instrumentos ou equipamentos utilizados no corte, menores serão os danos causados aos tecidos, contribuindo para maior vida-de-prateleira. Esta operação é tão crítica, que em países desenvolvidos já existem as chamadas "water knives", que cortam hortaliças e frutas com um fino jato de água a alta pressão (3000 kPa) (Heiland et al., 1990).

Para que se possa entregar ao consumidor uma fruta ou hortaliça minimamente processada, com a aparência de produto recém-colhido e com qualidades de excelência, em termos nutricionais, sensoriais e microbiológicos, outros fatores devem ser observados durante seu preparo e manuseio. Principalmente, se for levado em consideração, que um período mínimo de 7 dias é requerido para o consumo a nível regional, ou 7-15 dias, em nível de país, com dimensões continentais, como o Brasil.

Frutas e hortaliças minimamente processadas geralmente são muito mais perecíveis do que quando intactas porque são submetidas a severos estresses físicos advindos principalmente do descascamento e corte. Estes danos mecânicos aumentam o metabolismo destes produtos, com o conseqüente aumento da taxa de respiração e, em alguns casos, com o aumento da taxa de produção de etileno (Rosen \& Kader, 1989). Mesmo no caso de órgãos de reserva, como os bulbos, raízes, tubérculos e rizomas, que naturalmente possuem uma vida de pós-colheita relativamente longa (Kasmire et al., 1992b), quando submetidos ao processamento mínimo, passam a ser altamente perecíveis, com uma vida de prateleira muito curta. Batatinhas podem ser armazenadas até 10 meses a $5^{\circ} \mathrm{C}$ (Kasmire et al., 1992b), porém, quando minimamente processadas em "palitos" e armazenadas a $5^{\circ} \mathrm{C}$, possuem uma vida-de-prateleira de somente 2 semanas (O’Beirne \& Ballantyne, 1987).

Com esta alta perecibilidade, alguns fatores que afetam a qualidade destes produtos devem ser observados. 


\subsubsection{Fatores que influenciam a qualidade de produtos processados minimamente}

\subsubsection{Temperatura}

Como já mencionado anteriormente, as frutas e hortaliças minimamente processadas são organismos vivos. Este processo de vida é regulado pela ação catalítica de grandes moléculas de proteínas, chamadas enzimas. A atividade de uma enzima depende da temperatura e aumenta de duas a quatro vezes para cada aumento de $10^{\circ} \mathrm{C}$, nas condições onde ela se encontra (Mitchell et al., 1972). A temperatura é, portanto, um fator determinante do potencial da vida-de-prateleira de produtos minimamente processados e das suas taxas de deterioração.

Watada et al.(1996), estudando a taxa de respiração de brócolos minimamente processados, verificaram que produziram 12,9; 22,6 e 41,2 $\mathrm{ml} \cdot \mathrm{CO}_{2} \cdot \mathrm{Kg}^{-1} \cdot \mathrm{h}^{-1}$, quando armazenados a $0 ; 5$ e $10^{\circ} \mathrm{C}$, respectivamente.

Além de reduzir o metabolismo das hortaliças e também suas taxas de respiração, baixas temperaturas retardam outros processos fisiológicos/bioquímicos e microbiológicos causadores da deterioração e reduzem os riscos de desenvolvimento de microrganismos patogênicos ao homem.

Temperaturas maiores, $15^{\circ} \mathrm{C}$, induzem, em um período menor, a maior atividade da enzima fenilalanina-amonia-liase em alfaces minimamente processadas, quando comparadas com a temperatura de $5^{\circ} \mathrm{C}$ (López-Gálvez et al., 1996), produzindo a coloração escura em folhas de alface (Ke \& Saltveit, 1989). Da mesma forma acontece na descoloração (cor branca) de cenouras (Howard et al., 1994).

Temperaturas superiores a $5^{\circ} \mathrm{C}$, associadas a altas umidades relativas e baixos níveis de $\mathrm{O}_{2}$ no interior das embalagens, favorecem o risco de bactérias patogênicas ao homem, principalmente as dos gêneros Clostridium, Yersinia e Listeria (Cantwell, 1992).

Portanto, baixas temperaturas são requisitos essenciais e obrigatórios para a conservação de hortaliças minimamente processadas. Daí a necessidade de pré-resfriá- 
las logo após a colheita e manter a cadeia do frio durante todo o processo de preparo, manuseio e distribuição.

$\mathrm{O}$ ideal seria a utilização de temperaturas muito próximas ou iguais a $0^{\circ} \mathrm{C}$, porém, no Brasil, tem-se tornado freqüente a utilização de temperaturas ao redor de $5^{\circ} \mathrm{C}$ e algumas vezes de $10-12^{\circ} \mathrm{C}$.

Assim, outros fatores devem ser considerados visando hortaliças "prontas para o uso" com excelentes qualidades visuais, nutricionais e microbiológicas.

\subsubsection{Atmosfera modificada}

Através do processo respiratório, frutas e hortaliças inteiras ou minimamente processadas tendem a modificar a atmosfera em que estão, no interior de embalagens de filmes poliolefínicos. Funcionando como barreiras às trocas gasosas $\left(\mathrm{O}_{2}, \mathrm{CO}_{2}, \mathrm{C}_{2} \mathrm{H}_{4} \mathrm{e}\right.$ vapor d'água) entre o interior das embalagens e o ambiente externo, à medida que o tecido vegetal respira, há a tendência de decréscimo nos níveis de $\mathrm{O}_{2}$ e de acréscimo nos níveis de $\mathrm{CO}_{2}$ ao redor destes tecidos. Esta modificação da atmosfera faz com que frutas e hortaliças respirem cada vez menos, diminuindo seus metabolismos. Associada a baixas temperaturas, esta técnica tem se mostrado muito eficiente em prolongar a vida de pós-colheita de muitos destes produtos, tanto na forma in natura (Lioautas, 1988) como na de minimamente processadas (Watada \& Qi, 1999; Kader \& Watkins, 2000).

$\mathrm{O}$ efeito aditivo de baixas temperaturas associadas a baixas concentrações de $\mathrm{O}_{2}$ e elevadas de $\mathrm{CO}_{2}$, na taxa respiratória de brócolos minimamente processados é muito bem ilustrado em Watada et al.(1996), onde se percebe redução de 2 a 3 vezes na taxa respiratória desta hortaliça quando são submetidas à modificação da atmosfera nas diferentes temperaturas.

Níveis reduzidos de $\mathrm{O}_{2}$ e elevados de $\mathrm{CO}_{2}$ também contribuem para que as frutas e hortaliças produzam menos etileno e para a redução da sensibilidade destes produtos a este gás. Conseqüentemente, retardam o amadurecimento e a senescência dos tecidos vegetais (Kader, 1992). 
Porém, concentrações de $\mathrm{CO}_{2}$ acima daquelas toleradas pelas diferentes frutas e hortaliças ou de $\mathrm{O}_{2}$ muito baixas $(<1$ a $2 \%$ ) podem induzir à respiração anaeróbica, causando a produção de odores e sabores desagradáveis (Kader, 1992).

Em repolhos minimamente processados, concentrações de $\mathrm{CO}_{2}$ de $13 \%$ e de $\mathrm{O}_{2}$ iguais a 2\% induziram o aparecimento de odores desagradáveis, após 9 a 10 dias de armazenamento a $3^{\circ} \mathrm{C}$ e 70 a $80 \%$ de umidade relativa (Pirovani et al., 1997).

Concentrações de $\mathrm{CO}_{2}$ superiores a $30 \%$ ou de $\mathrm{O}_{2}$ menores que $2 \%$ induziram à deterioração de cenouras raladas, devido ao crescimento de bactérias lácticas, enquanto níveis de $15-20 \% \quad \mathrm{CO}_{2}$ e de $5 \% \mathrm{O}_{2}$ promoveram uma satisfatória conservação deste produto (Carlin et al., 1990).

A manutenção de níveis de $1-2 \% \quad \mathrm{O}_{2}$ e $3-4 \% \quad \mathrm{CO}_{2}$ no interior de embalagens contendo batatas "palito", previamente imersas em solução a 10\% de ácido ascórbico, inibiu o escurecimento enzimático por um período de 1 semana a $5^{\circ} \mathrm{C}\left(\mathrm{O}^{\prime}\right.$ Beirne \& Ballantyne, 1987).

Resultados semelhantes foram obtidos em outro estudo com batatas em "cubos", "fatiadas" ou "palitos" (Giannuzzi et al., 1988). Estes autores relatam que embalagem à vácuo dobrou a vida-de-prateleira destes produtos quando comparados com os embalados em filme de polietileno de baixa densidade.

Mais recentemente, recobrimentos comestíveis de polissacarídeos, proteínas e lipídios têm sido estudados para melhorar a textura e reduzir a perda de umidade, a respiração e as alterações de cor de hortaliças minimamente processadas. Esta tecnologia ainda está em seu estágio inicial de desenvolvimento e a maioria dos resultados estão descritos em publicações científicas e patentes (Baldwin et al., 1995).

\subsubsection{Umidade relativa}

A perda de água é uma das principais causas de deterioração de frutas e hortaliças após a colheita, por produzirem o amarelecimento e o enrugamento de seus tecidos. 
Como a maioria delas possui entre 80 a $95 \%$ de água (em relação ao peso) e a umidade relativa dos espaços intercelulares é muito próxima de $100 \%$, a tendência é quase sempre de o vapor d'água escapar destes espaços, através do processo de transpiração. Este processo ocorre porque a umidade relativa do ambiente onde se encontram é freqüentemente menor que $100 \%$. E, quanto maior a relação superfície/volume, maior a taxa de transpiração da fruta ou hortaliça (Hardenburg et al., 1986).

Hortaliças minimamente processadas, devido ao corte, apresentam sempre maior relação superfície/volume do que quando inteiras, facilitando ainda mais a perda de água de seus tecidos. Exemplo típico é o caso de cenoura minimamente processada, cuja principal causa de sua rápida deterioração é a perda de turgidez, portanto, de textura, e o aparecimento da coloração branca em sua superfície. Os consumidores associam a perda de textura e a coloração branca ao envelhecimento do produto, e alguns pesquisadores, à desidratação de superfícies que sofreram algum tipo de abrasão (Tatsumi et al., 1991).

Apesar da importância da umidade relativa do ambiente na extensão da vida-deprateleira de hortaliças minimamente processadas, muito pouco se tem pesquisado sobre $\mathrm{o}$ assunto. Talvez porque os filmes poliolefínicos atuem como barreiras à perda de água dos tecidos vegetais.

Barth \& Zhuang (1996) observaram que brócolos minimamente processados, armazenados a $5^{\circ} \mathrm{C}$ e $60 \%$ de umidade relativa, mantiveram seu conteúdo de umidade, quando embalados em filmes poliméricos.

Resultados semelhantes foram obtidos por Pirovani et al. (1997) que relatam o controle de perda de peso em repolhos minimamente processados, armazenados a $3^{\circ} \mathrm{C}$ e 70 a $80 \%$ de umidade relativa, e embalados em diferentes tipos de filmes flexíveis: mono-orientados de polipropileno; poliolefínico de camadas múltiplas; ou de PVC.

Entretanto, Howard \& Griffin (1993) e Howard et al. (1994) questionam a eficiência dos filmes flexíveis no controle do murchamento de frutas e hortaliças minimamente processadas, afirmando que, talvez, os recobrimentos comestíveis constituam-se em melhor barreira ao vapor d'água destes produtos. 


\subsubsection{Fisiológicos e bioquímicos}

O aumento da respiração de hortaliças minimamente processadas já foi ilustrado sob os itens "Temperatura" e "Atmosfera Modificada". Da mesma forma, alguns aspectos indesejáveis do aumento da biossíntese de etileno, provocada por ferimentos nos tecidos vegetais, foram comentados sob o .item "Atmosfera Modificada".

Do ponto de vista bioquímico, reações enzimáticas são as responsáveis pelas deteriorações sensoriais, tais como: odor e sabor desagradável, alteração da cor (escurecimento ou descoloração) e perda de firmeza das hortaliças minimamente processadas.

A peroxidação enzimática de ácidos graxos insaturados é um exemplo das modificações bioquímicas de aromas naturais das hortaliças minimamente processadas. Esta peroxidação é catalisada pela lipoxigenase e leva à formação de inúmeros aldeídos e cetonas, responsáveis pelos sabores e odores desagradáveis (Hildebrand, 1989).

Outra enzima estimulada por ferimentos é a peroxidase, que desempenha um importante papel no processo de lignificação de tecidos danificados (Ke \& Saltveit, 1989). A formação de lignina pode ser a responsável pela coloração branca da superfície de cenouras minimamente processadas (Bolin e Huxsoll, 1991).

Fenilalanina-amonia-liase, polifenoloxidase e outras enzimas que contribuem direta ou indiretamente para o escurecimento enzimático também são produzidas em função de estresses mecânicos (Rolle \& Chism, 1987).

Enzimas pectinolíticas e proteolíticas são as responsáveis pela perda de firmeza das hortaliças minimamente processadas (Varoquaux \& Wiley, 1994).

Vários têm sido os métodos utilizados na tentativa de inativar ou retardar a atividade destas enzimas. Dentre eles, o uso de ácidos ascórbico e cítrico, hipoclorito de sódio, EDTA, sais de cálcio, calor, recobrimentos comestíveis, absorvedores de etileno, etc.. (Sapers et al., 1994). Porém, como a regulação dos processos enzimáticos permanece desconhecida, a eficiência dos diferentes métodos de controle dessas reações não tem sido satisfatória. 
Kim \& Klieber (1997), estudando o efeito de cloreto de cálcio, ácido cítrico e ácido ascórbico, na concentração de 10 g.L $\mathrm{L}^{-1}$, em couve chinesa minimamente processada, observaram que nenhum dos tratamentos foi eficiente no controle do escurecimento enzimático, nas faces que sofreram a ação do corte. E, como esperado, o escurecimento ocorreu mais rapidamente a 5 do que a $0^{\circ} \mathrm{C}$.

\subsubsection{Microrganismos}

Naturalmente, as hortaliças e frutas já são bem conhecidas como fontes potenciais de microrganismos relevantes em saúde pública, isto é, estão muito relacionadas à higiene e incidentes de toxinfecção alimentar. Além do perigo de transmissão de patógenos por esses produtos, há também a possibilidade de aumento da população microbiana inicial, composta de microrganismos deteriorantes, que reduzam significativamente a vida útil dessas hortaliças e frutas. Dentre os deteriorantes que mais se destacam no caso dos produtos hortícolas estão, especialmente, os bolores e as leveduras e o grupo de bactérias coliformes totais (Beuchat, 1996).

Os bolores e leveduras têm seu habitat natural em vegetais, sendo, portanto, parte da sua microbiota e são considerados contaminantes naturais, enquanto os coliformes totais são típicos microrganismos indicadores de higiene em alimentos. A significância prática dos indicadores é que sua presença, em números elevados, aponta para a falta de higiene do alimento, indicando a possibilidade de que patógenos intestinais de importância em saúde pública possam estar presentes nesse produto, uma vez que esses microrganismos têm como habitat principal o trato gastrintestinal de homens e animais (Beuchat, 1996).

Como agravante, as condições de alta umidade relativa e baixos níveis de oxigênio no interior das embalagens de hortaliças minimamente processadas favorecem ainda mais o risco destas bactérias patogênicas e microrganismos que causam a deterioração dos tecidos vegetais. 
Um grande número de microrganismos tem sido encontrado em produtos minimamente processados, incluindo leveduras, coliformes, coliformes fecais, microbiotas mesofílicas e pectinolíticas, bolores, etc...(Nguyen-the \& Carlin, 1994).

Em couve-flor é comum encontrar bactérias anaeróbicas, psicrófilas (Garg et al., 1993), mesofílicas, leveduras e bolores (Nguyen-the \& Carlin, 1994).

Em repolho, há a predominância de microbiota mesofílica, bactéria lática, leveduras e bolores (Nguyen-the \& Carlin, 1994).

Como regra geral, recomenda-se uma boa sanitização de toda a planta de processamento, inclusive dos instrumentos e equipamentos utilizados, a utilização de luvas, máscaras, aventais e botas por parte dos operadores, o uso de água clorada (50200 ppm do princípio ativo) para a lavagem das hortaliças e um controle bastante rigoroso da temperatura (se possível, a mais próxima de $0^{\circ} \mathrm{C}$ ).

Mais importante ainda são as análises microbiológicas freqüentes de amostras das hortaliças minimamente processadas, em todas as etapas, desde a produção até a distribuição em nível de consumidor. 


\section{EFEITO DA TEMPERATURA NOS METABOLISMOS DE COUVE-FLOR E RÚCULA INTEIRAS E MINIMAMENTE PROCESSADAS}

\section{Resumo}

Couves-flores (inflorescência sem as folhas), floretes de couves-flores, rúculas inteiras (folhas unidas pela base, sem raízes) e minimamente processadas (folhas soltas) foram mantidas a 1,5 e $11^{\circ} \mathrm{C}$ para se verificar a influência da temperatura em suas taxas respiratórias, quocientes de temperatura $\left(\mathrm{Q}_{10}\right)$ e produções de etileno. Observou-se que as taxas respiratórias das couves-flores e dos floretes não diferiram entre si a $1^{\circ} \mathrm{C}$, a $5^{\circ} \mathrm{C}$ ou a $11^{\circ} \mathrm{C}$ e apresentaram, em todas as temperaturas, leve declínio até o $16^{\circ}$ dia. Quando mantidos a $1^{\circ}$ e a $5^{\circ} \mathrm{C}$, tiveram a mesma taxa respiratória, diferindo significativamente dos armazenados a $11^{\circ} \mathrm{C}$. Na faixa de temperatura de 1 a $11^{\circ} \mathrm{C}$, o quociente de temperatura $\left(\mathrm{Q}_{10}\right)$ para couves-flores foi de 2,2 e para os floretes, de 2,1. As taxas respiratórias das rúculas (unidas pela base) e das folhas soltas não diferiram entre si a 1 ou a $5^{\circ} \mathrm{C}$, durante os 16 dias de experimentação. A partir do $4^{\circ}$ dia a $11^{\circ} \mathrm{C}$, as folhas soltas apresentaram taxas de respiração superiores às das rúculas, aumentando cada vez mais a diferença, até ser quase o dobro nos $14^{\circ}$ e $16^{\circ}$ dias de armazenamento. A partir do $6^{\circ}$ dia a $5^{\circ} \mathrm{C}$, uma leve mudança para a coloração amarela foi observada nas folhas soltas e nas rúculas, sem haver comprometimento de sua comercialização. A partir do $2^{\circ}$ dia a $11^{\circ} \mathrm{C}$, observou-se início de pigmentação amarela nas rúculas inteiras e minimamente processadas, sendo que no $6^{\circ}$ dia estavam todas bem amarelas e não mais comercializáveis. $\mathrm{O} \mathrm{Q}_{10}$ médio para as folhas soltas foi de 5,74 e para as rúculas inteiras, 3,54. A produção de etileno das couves-flores, floretes, rúculas inteiras e minimamente 
processadas ficou abaixo do nível de detecção do cromatógrafo a gás e, portanto, menor que $0,1 \mu \mathrm{L} . \mathrm{L}^{-1}$.

Palavras-chave: taxa de respiração, produção de etileno, Brassica oleracea L., Eruca sativa Miller

\section{Summary}

Respiratory activity, temperature quotient $\left(\mathrm{Q}_{10}\right)$ and ethylene production were determined for minimally processed cauliflower ("florets") and salad rocket ("loose leaves") and their whole counterparts, held at 1,5 and $11^{\circ} \mathrm{C}$. The slight decrease in the respiration rate of the intact cauliflower heads and the florets was similar at the three temperatures. The respiratory activity of the intact heads and the florets held at $1^{\circ} \mathrm{C}$ did not differ from those held at $5^{\circ} \mathrm{C}$, but did differ from those held at $11^{\circ} \mathrm{C}$. In the temperature range from $1^{\circ}$ to $11^{\circ} \mathrm{C}$, the temperature quotients were almost the same for the heads $\left(\mathrm{Q}_{10}=2.2\right)$ and the florets $\left(\mathrm{Q}_{10}=2.1\right)$. The same behavior was shown for the salad rockets held at $1^{\circ}$ and $5^{\circ} \mathrm{C}$, the respiration rates being the same for the whole and the fresh-cut products during the 16-day-trial period. However, at $11^{\circ} \mathrm{C}$, the $\mathrm{CO}_{2}$ concentration was found to be greater for the minimally processed salad rockets as compared to the whole product as from the $4^{\text {th }}$ day, the difference increasing to almost twice the value of the whole product on the $14^{\text {th }}$ and $16^{\text {th }}$ days. As from the $6^{\text {th }}$-day at $5^{\circ} \mathrm{C}$, the salad rockets became light green with a slight yellow pigmentation. At $11^{\circ} \mathrm{C}$, this vegetable started becoming yellow after 2 days for both the whole product and the minimally processed loose leaves. By he $6^{\text {th }}$ day all the leaves were so yellow they were no longer marketable. The $\mathrm{Q}_{0}$ values of the whole and fresh-cut salad rockets were 3.54 and 5.74 respectively. Ethylene was not detectable from any of these products at the level of detection of the gas chromatograph, that is, they were below $0.1 \mu \mathrm{L}^{-\mathrm{L}^{-1}}$.

Key-words: respiration rate, ethylene production, Brassica oleracea L., Eruca sativa Miller. 


\subsection{Introdução}

A demanda dos mercados varejista e institucional por hortaliças e frutas que tenham sido submetidas a um mínimo de processamento após a colheita tem crescido consideravelmente em anos recentes.

O preparo destes produtos envolve, geralmente, operações como abrasão, descascamento, corte, etc. (Cantwell, 1992), de forma que o comportamento dos tecidos destas hortaliças e frutas é típico daqueles observados em vegetais que sofreram danos físicos ou mecânicos ou que foram submetidos a condições de estresse. As alterações fisiológicas incluem aumentos das taxas de respiração e produção de etileno e da susceptibilidade ao escurecimento enzimático e microrganismos. Conseqüentemente, deterioram e senescem mais rapidamente (King \& Bolin, 1989).

Minimizar as consequiências negativas desses danos ou estresses resulta em uma vida-de-prateleira maior e em uma melhor manutenção das qualidades de aparência, nutricional e de sabor, odor destes produtos.

Muitos fatores podem afetar a intensidade das respostas aos danos físicos ou estresses em hortaliças e frutas minimamente processadas. Dentre eles destacam-se: espécie, variedade, estádio de maturidade fisiológica, extensão do ferimento, temperatura, concentrações de oxigênio e de gás carbônico, pressão de vapor de água, etc. (Brecht, 1995). Porém, de acordo com este mesmo autor, a temperatura é o mais importante deles e o resfriamento, antes e durante as etapas de processamento, transporte, distribuição e exposição nas gôndolas dos supermercados reduz os impactos negativos causados pelos danos físicos ao tecido vegetal.

Como os produtos minimamente processados geralmente são muito mais perecíveis do que os que thes deram origem, eles deveriam ser mantidos a temperaturas menores do que as recomendadas para estes últimos. $\mathrm{O}$ ideal seria a $0^{\circ} \mathrm{C}$. Entretanto, por razões de ordem econômica, o que se encontra na prática são temperaturas ao redor de 5 a $10^{\circ} \mathrm{C}$. Neste nível, a deterioração pode ser apressada substancialmente porque o quociente de temperatura de reações biológicas, $\mathrm{Q}_{10}$, oscila de 3 a 7 (Schlimme, 1995). 
Watada et al.(1996) compararam as taxas de respiração de várias hortaliças e frutas inteiras e minimamente processadas a $0,5,10$ e $20^{\circ} \mathrm{C}$ e observaram que a produção de gás carbônico dos produtos que sofreram o processamento mínimo foi geralmente superior à produção das hortaliças e frutas inteiras. $\mathrm{O}$ aumento nas taxas respiratórias chegou a valores superiores a $100 \%$ para alfaces e quivi. Descrevem também que a respiração dos produtos minimamente processados aumentou com a temperatura, sendo que a intensidade deste aumento variou em função do tipo de hortaliça ou fruta. $\mathrm{Na}$ faixa de 0 a $10^{\circ} \mathrm{C}, \mathrm{o} \mathrm{Q}_{10}$ de vários produtos minimamente processados foi maior, de outros foi similar e de poucos foi menor que o dos produtos inteiros.

Acredita-se que este aumento nas taxas respiratórias de produtos minimamente processados é conseqüência do nível elevado de etileno produzido por tecidos vegetais que sofreram danos físicos (Abeles et al., 1992).

Abe \& Watada (1991) observaram que o etileno produzido pela ação física de processamentos mínimos foi suficiente para acelerar o amolecimento de bananas e quivis e a perda de clorofila em espinafres, mas não em brócolos.

Vários têm sido os estudos sobre a influência da temperatura no metabolismo de diversas frutas e hortaliças minimamente processadas. Contudo, a literatura contempla muito pouco sobre couve-flor (Behrsing et al., 1998) e rúcula (Piergiovanni et al., 1999) minimamente processadas.

Como o perfeito entendimento do comportamento respiratório, de produção de etileno de produtos minimamente processados a baixas temperaturas é de vital importância para o desenvolvimento de embalagens de filmes flexíveis adequadas e para o manuseio correto desses produtos, o objetivo deste estudo foi o de verificar a influência da temperatura nas taxas respiratórias e de produção de etileno de couvesflores e rúculas inteiras e minimamente processadas. 


\subsection{Materiais e métodos}

Couves-flores Júlia e rúculas Folha-Larga foram colhidas, nas primeiras horas da manhã, de plantações comerciais dos municípios de Sorocaba (SP) e Sumaré (SP), respectivamente.

Após a colheita, os produtos foram imediatamente transportados para o Centro de Pesquisa e Desenvolvimento de Hortícolas (FRUTHOTEC), do Instituto de Tecnologia de Alimentos - ITAL, Campinas (SP), onde foram mantidos, por aproximadamente 03 (três) horas, em câmaras frigoríficas a $5 \pm 1^{\circ} \mathrm{C}$ e $90 \pm 5 \%$ de umidade relativa.

No início das tardes dos dias das colheitas, as hortaliças foram transferidas para uma área a $16^{\circ} \mathrm{C}$, limpa e higienizada, para serem submetidas às operações de processamento mínimo.

Em um lote, as folhas; e, em outro, as folhas e os floretes foram separados da couve-flor com o auxílio de facas novas, muito bem afiadas, para que suas bases sofressem os menores danos possíveis. Desta forma, obtiveram-se couves-flores (cabeças inteiras, sem as folhas) e floretes para serem utilizados nas operações subseqüentes do processamento mínimo.

Com essas facas cortaram-se também as raízes das rúculas, tomando-se o cuidado para que as folhas permanecessem unidas por suas bases.

Couves-flores, floretes e rúculas foram inicialmente lavados em 200 L de água a $5^{\circ} \mathrm{C}$, contida em uma banheira de aço inoxidável, com capacidade para $500 \mathrm{~L}$. Nesta primeira lavagem, foram retiradas sujeiras maiores, como partículas de solo presentes nas folhas das rúculas, etc.

Em seguida, foram novamente lavadas em água a $5^{\circ} \mathrm{C}$, para certificação de que toda a sujeira mais grossa havia sido eliminada.

Com a finalidade de facilitar a remoção de possíveis insetos e complementar a lavagem, as hortaliças foram imersas, por 30 segundos, em uma solução a $1 \%$ de SUMA-D29 ${ }^{\circledR}$. Este produto é um sabão líquido (Divoplus v3-2) apropriado a frutas e hortaliças, tendo como princípio ativo, sabão potássico de ácidos graxos de soja/coco e é fabricado pela Diversey Lever - Indústrias Gessy Lever Ltda. Esta solução foi preparada 
com água previamente resfriada a $5^{\circ} \mathrm{C}$, como toda a água utilizada durante as outras etapas dos processamentos mínimos.

O excesso de sabão líquido das couves-flores, floretes e rúculas foi retirado por imersão em água a $5^{\circ} \mathrm{C}$.

Somente, então, é que foram imersas em solução a $0,66 \%$ de SUMAVEG ${ }^{\circledR}(3 \%$ de cloro ativo), por 5 minutos, com o intuito de sanitização. Este produto tem como princípio ativo o Dicloro-S-Triazinatriona Sódica Diidratada e é fabricado pela Diversey Lever - Indústrias Gessy Lever Ltda.

Finalmente, as couves-flores e floretes foram colocados em saquinhos de malha de fibra sintética, para serem centrifugados por 30 segundos, em equipamento "AngeloPo", de fabricação italiana, com 750 giros/minuto. Estes saquinhos permitem a livre passagem de água do produto para a centrífuga e têm a finalidade de protegê-lo de possíveis danos físicos durante a operação de centrifugação.

As rúculas, sem serem colocadas nos saquinhos, foram centrifugadas por 45 segundos.

Somente após a centrifugação é que parte das rúculas teve sua base cortada para que as folhas ficassem soltas.

Após, as hortaliças foram selecionadas e padronizadas quanto ao tamanho, ausência de defeitos e murchamento (especialmente em rúculas).

Procedeu-se à pesagem, de forma a se obter lotes de aproximadamente $250 \mathrm{~g}$ de rúculas (unidas ou não pela base), $780 \mathrm{~g}$ de couves-flores (peso médio das cabeças) e $530 \mathrm{~g}$ de floretes.

Os lotes foram colocados em frascos de acrílico de $5 \mathrm{~L}$ (couve-flor) e de vidro de 3,6 L (floretes, rúculas), conectados a fluxcentros (Claypool \& Keefer, 1942; Calbo, 1989), instalados em câmaras frigoríficas a 1,5 e $11 \pm 1^{\circ} \mathrm{C}$. Desta forma, as hortaliças receberam um fluxo contínuo de ar umidificado e frio.

Os fluxos de ar foram selecionados para assegurar que o acúmulo de gás carbônico no interior dos frascos não excedesse a $0,25 \%$, com base no calor vital do produto, nas diferentes temperaturas de armazenamento. 
Antes de ir para os fluxcentros, o ar passava por uma solução a $20 \%$ de cal hidratada e em outra, a $20 \%$ de permanganato de potássio, para que ficasse livre de gás carbônico e de etileno, respectivamente.

As taxas respiratórias (gás carbônico) e de produção de etileno foram determinadas utilizando-se $1000 \mu \mathrm{L}$ de ar retirados de cada um dos frascos, com o auxílio de uma seringa à prova de vazamentos (“gas tight”).

Essas amostras de ar foram injetadas em um Cromatógrafo a Gás, marca Varian, modelo Star 3400. Equipado com coluna Hyesep N, de $1 \mathrm{~m}$ de comprimento e detetor de condutividade térmica ("TCD") para determinação de $\mathrm{CO}_{2}$, foi operado a 70, 60 e $140^{\circ} \mathrm{C}$ para injetor, coluna e detetor, respectivamente. O hidrogênio foi utilizado como gás de arraste a $26 \mathrm{~mL} \cdot \mathrm{min}^{-1}$, com ar e hidrogênio a $300 \mathrm{~mL} \cdot \mathrm{min}^{-1}$ e $10 \mathrm{~mL} \cdot \mathrm{min}^{-1}$. Para as determinações de etileno $\left(\mathrm{C}_{2} \mathrm{H}_{4}\right)$, foram utilizados uma coluna Porapak- $\mathrm{N}$, de $1 \mathrm{~m}$ de comprimento e o detetor de ionização de chamas ("FID”) no mesmo cromatógrafo. As mesmas temperaturas de injetor, coluna e detetor foram utilizadas, neste caso, tendo o hidrogênio como gás de arraste, a $20 \mathrm{~mL} \cdot \mathrm{min}^{-1}$ e o ar sintético e hidrogênio a 300 e 10 mL.min ${ }^{-1}$, respectivamente.

O gás carbônico foi quantificado pela calibração com padrões de $500 \mu \mathrm{L} . \mathrm{L}^{-1} \mathrm{e}$ $10 \%$ de $\mathrm{CO}_{2}$ e o etileno, com padrão de $9,8 \mu \mathrm{L} . \mathrm{L}^{-1}$.

Análises de $\mathrm{CO}_{2}$ e $\mathrm{C}_{2} \mathrm{H}_{4}$ foram realizadas nos $1^{\circ}$ e $2^{\circ}$ dias da instalação dos experimentos e, após, a cada 2 dias, até o $16^{\circ}$ dia para as rúculas e $18^{\circ}$ dia, para as couves-flores.

As velocidades das reações de respiração ou os quocientes de temperatura $\left(Q_{10}\right)$ foram calculados com base nas taxas de produção de $\mathrm{CO}_{2}$ a $1^{\circ} \mathrm{C}$ e a $11^{\circ} \mathrm{C}$, de acordo com a seguinte fórmula:

$$
\mathrm{Q}_{10}=\frac{R\left(T+10^{\circ} C\right)}{R\left(\mathrm{~T}^{\circ} \mathrm{C}\right)}
$$

onde:

$\mathrm{R}\left(\mathrm{T}^{\circ} \mathrm{C}\right)=$ taxa respiratória à temperatura $\mathrm{T}^{\circ} \mathrm{C}$

$\mathrm{R}\left(\mathrm{T}+10^{\circ} \mathrm{C}\right)=$ taxa respiratória à temperatura $\mathrm{T}+10^{\circ} \mathrm{C}$ 
Em cada temperatura de experimentação $\left(1,5\right.$ e $\left.11^{\circ} \mathrm{C}\right)$ havia 04 frascos, contendo, em cada um, aproximadamente $780 \mathrm{~g}$ de couves-flores (cabeça inteira, sem as folhas) e 04 frascos contendo, em cada um, $530 \mathrm{~g}$ de floretes. Da mesma forma, em cada uma das câmaras frigoríficas a 1,5 e $11^{\circ} \mathrm{C}$, havia 04 frascos contendo, em cada um, 250 $\mathrm{g}$ de rúculas, com as folhas unidas pela base e 04 frascos com $250 \mathrm{~g}$ de folhas de rúculas, sem estarem unidas pela base.

$\mathrm{O}$ delineamento utilizado foi o inteiramente casualizado com quatro repetições para cada tratamento. Após os dados terem sido submetidos à análise de variância, as médias de cada tratamento foram comparadas pelo teste Tukey a 5\% de probabilidade, utilizando-se o programa estatístico SAS (SAS Institute, 1996).]

\subsection{Resultados e discussão}

\subsubsection{Taxas respiratórias de couves-flores e floretes}

As taxas respiratórias das couves-flores e floretes apresentaram suave decréscimo durante o armazenamento, independentemente da temperatura (Figura 1).

Este comportamento, descrito há muito tempo para folhas, outros órgãos e plantas inteiras de girassóis (Kidd et al., 1921) e após, para frutos (Biale, 1960), já era esperado. Mais recentemente, Kays (1991) menciona que a perda de reservas de energia, que eventualmente resulta na morte dos tecidos e em acelerada senescência, é especialmente crítica em produtos como folhas, flores e outras estruturas que não funcionam, como sítio de armazenamento de carbono, razão pela qual exibem um lento e progressivo declínio em suas taxas de respiração até que sejam invadidas por microrganismos.

No $1^{\circ}$ dia de armazenamento, as couves-flores a $1^{\circ} \mathrm{C}$ respiravam a $37.52 \mathrm{mg}$ $\mathrm{CO}_{2} \cdot \mathrm{kg}^{-1} \cdot \mathrm{h}^{-1}$; significativamente menos que os floretes a $11^{\circ} \mathrm{C}$, que produziam $99,85 \mathrm{mg}$ $\mathrm{CO}_{2} \cdot \mathrm{kg}^{-1} \cdot \mathrm{h}^{-1}$. No último dia de armazenamento $\left(18^{\circ} \mathrm{dia}\right)$, os floretes a $1^{\circ} \mathrm{C}$ foram os que 
apresentaram a menor taxa respiratória $\left(18,61 \mathrm{mg} \mathrm{CO}_{2} \cdot \mathrm{kg}^{-1} \cdot \mathrm{h}^{-1}\right)$ e aqueles a $11^{\circ} \mathrm{C}$, a maior taxa de produção de gás carbônico $\left(52,38 \mathrm{mg} \mathrm{CO} 2 \cdot \mathrm{kg}^{-1} \cdot \mathrm{h}^{-1}\right)$.

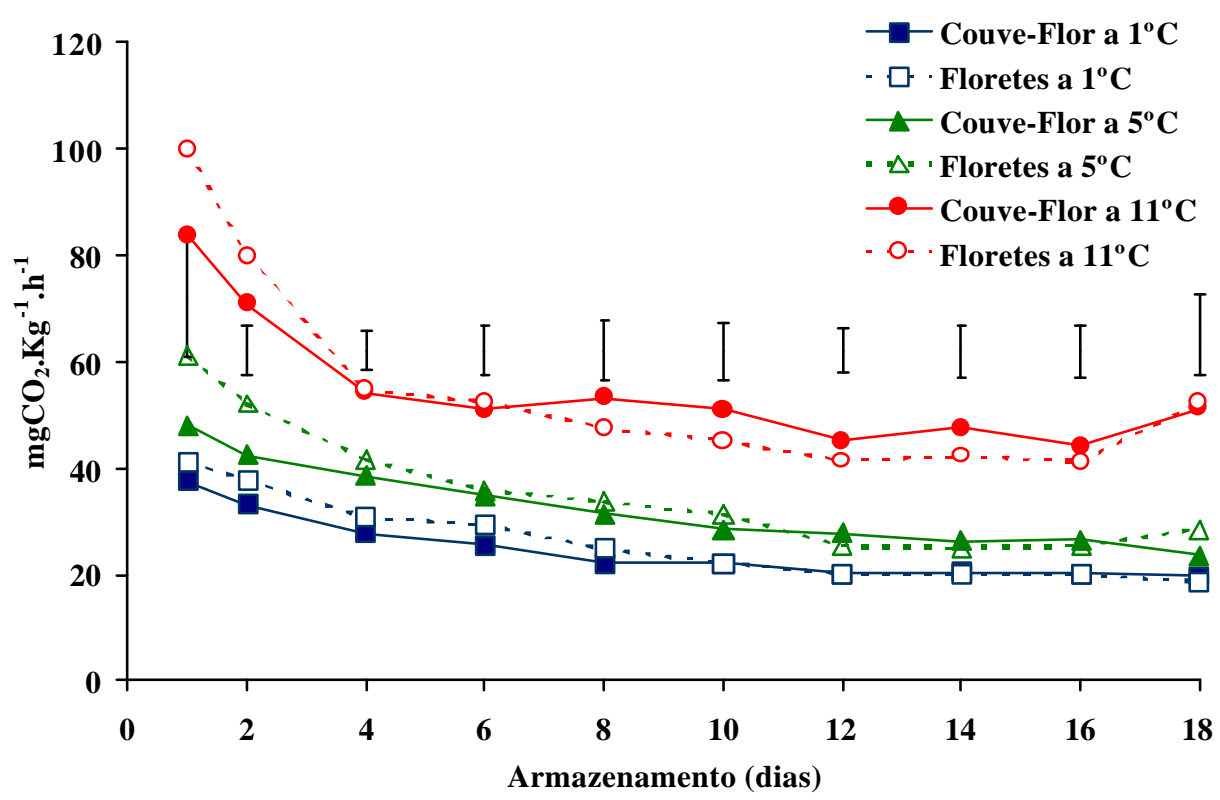

Figura 1 - Respiração de couve-flor e floretes a 1,5 e $11^{\circ} \mathrm{C}$, em mg $\mathrm{CO}_{2} \cdot \mathrm{kg}^{-1} \cdot \mathrm{h}^{-1}$. Barras na vertical indicam a diferença mínima significativa (DMS) $(\mathrm{P} \leq 0.05)$.

Praticamente, durante todos os 18 dias de armazenamento, as produções de gás carbônico das couves-flores inteiras não diferiram significativamente das dos floretes, quando mantidos nas mesmas temperaturas. Estes resultados conferem com os obtidos por Behrsing et al. (1998) que relatam taxas de respiração semelhantes para cabeças intactas e floretes, após estes terem tido uma atividade respiratória maior, logo nas primeiras horas após o corte.

Produções elevadas de $\mathrm{CO}_{2}$ imediatamente após o corte têm sido relatadas por vários autores. Smyth et al. (1998) observaram que a taxa de respiração de alfaces minimamente processadas (tiras de $2 \times 1,55 \mathrm{~cm}$ ) decresceu de aproximadamente 470 pmol.g $\mathrm{g}^{-1} \cdot \mathrm{s}^{-1}$ (1 hora após o corte) para $125 \mathrm{pmol} \cdot \mathrm{g}^{-1} \cdot \mathrm{s}^{-1}$ (24 horas após o corte), permanecendo quase que constante até o final do experimento ( 80 horas). Em outro experimento, floretes de brócolos Green Valiant possuíam atividade respiratória 40\% 
superior à das cabeças inteiras, 7 horas após o processamento mínimo. Durante os 6 primeiros dias de armazenamento a $4^{\circ} \mathrm{C}$, estas atividades decresceram rapidamente, quase se igualando; porém, de acordo com Bastrash et al. (1993), os floretes ainda liberavam mais $\mathrm{CO}_{2}$ que as cabeças inteiras. Alguns outros exemplos de hortaliças em que a respiração das minimamente processadas não difere significativamente das intactas, que lhes deram origem, podem ser encontrados em Watada et al. (1996).

Laranjas sem sementes a $4^{\circ} \mathrm{C}$ (Rocha et al., 1995) e abacaxis Smooth Cayenne a $4,5^{\circ} \mathrm{C}$ (Budu et al., 2001) são exemplos de frutas em que o descascamento não interferiu significativamente em seus metabolismos (produção de $\mathrm{CO}_{2}$ ), quando comparados com os das frutas com casca.

A temperatura foi o fator que mais influenciou o metabolismo da couve-flor. Floretes armazenados a $1^{\circ}$ e a $5^{\circ} \mathrm{C}$ somente apresentaram taxa respiratória diferente nos $2^{\circ}$ e $4^{\circ}$ dias de armazenamento. Nos demais dias, embora a produção de $\mathrm{CO}_{2}$ dos floretes a $5^{\circ} \mathrm{C}$ fosse maior que a $1^{\circ} \mathrm{C}$, não se observaram diferenças estatísticas entre seus valores. Comportamento semelhante tiveram as couves-flores nestas temperaturas, diferindo somente nos $4^{\circ}$ e $6^{\circ}$ dias.

As respirações de couves-flores e floretes a $11^{\circ} \mathrm{C}$ não diferiram estatisticamente entre si durante o período estudado. Porém, diferiram das respirações destes mesmos produtos armazenados a $1^{\circ} \mathrm{C}$ e a $5^{\circ} \mathrm{C}$.

Vários têm sido os estudos que mostram a influência da temperatura na atividade metabólica de hortaliças minimamente processadas. Carnelossi (2000) relata que couves minimamente processadas, armazenadas a $1^{\circ} \mathrm{C}$, apresentaram uma taxa respiratória máxima em torno de $110 \mathrm{mg} \mathrm{CO} \cdot \mathrm{kg}^{-1} \cdot \mathrm{h}^{-1}$ e a $25^{\circ} \mathrm{C}$, essa taxa elevou-se para $200 \mathrm{mg}$ $\mathrm{CO}_{2} \cdot \mathrm{kg}^{-1} \cdot \mathrm{h}^{-1}$. Observou ainda que o efeito da temperatura foi maior nas primeiras horas após o processamento. Esta observação coincide com as do presente estudo, que mostra um maior efeito da temperatura em couves-flores e floretes até praticamente o $4^{\circ}$ dia de armazenamento.

Hong \& Kim (2001), em experimentos para verificar o efeito da temperatura sobre a taxa de respiração de cebolinhas cortadas com $10 \mathrm{~cm}$ de comprimento, 
verificaram níveis de $9,19 \mathrm{~mL} \mathrm{CO} 2 \cdot \mathrm{kg}^{-1} \cdot \mathrm{h}^{-1}$ a $0^{\circ} \mathrm{C}, 27,02 \mathrm{~mL} \mathrm{CO} \cdot \mathrm{kg}^{-1} \cdot \mathrm{h}^{-1}$ a $10^{\circ} \mathrm{C}$ e 78,74 $\mathrm{mL} \mathrm{CO} 2 \cdot \mathrm{kg}^{-1} \cdot \mathrm{h}^{-1}$ a $20^{\circ} \mathrm{C}$.

Estes resultados com cebolinhas, couve e couve-flor estão de acordo com vários outros dados de diferentes hortaliças mostrados em Watada et al. (1996), confirmando que as taxas de respiração de produtos minimamente processados aumentam com a temperatura e que o grau deste aumento varia em função do material vegetal. Por isso, estes autores sugerem que a temperatura ideal para a maioria destes produtos seria de $0^{\circ} \mathrm{C}$. Enfatizam, porém, que muitos deles são preparados, transportados e mantidos a $5^{\circ} \mathrm{C}$ e, algumas vezes, a temperaturas tão altas quanto $10^{\circ} \mathrm{C}$. Afirmam, ainda, que mantê-los em níveis tão elevados de temperatura, significa deterioração mais rápida, porque a velocidade das reações biológicas $\left(\mathrm{Q}_{10}\right)$ pode ser de 3 a 4 e, às vezes, até 7 vezes maior, nesta temperatura.

\subsection{2 $Q_{10}$ para couve-flor e floretes}

Dentro da faixa de temperatura deste experimento, 1 a $11^{\circ} \mathrm{C}$, o $\mathrm{Q}_{10}$ para couveflor inteira variou de $2,0\left(\right.$ nos $4^{\circ}$ e $6^{\circ}$ dias) a 2,6 (no $18^{\circ}$ dia), com média de 2,2, ao longo de todo o período de armazenamento (Figura 2).

Os floretes tiveram uma variação de 1,8 ( $4^{\circ}$ e $6^{\circ}$ dias $)$ a 2,8 (18 dia), com média de 2,1. Isto significa dizer que a taxa das reações biológicas, de couves-flores inteiras ou minimamente processadas em floretes, aproximadamente, duplica com um aumento de $10^{\circ} \mathrm{C}$ na temperatura do ambiente onde elas ocorrem. Embora estes valores estejam abaixo dos 3 a 4 e, às vezes 7, citados por Watada et al. (1996), eles também citam outras hortaliças que apresentam valores de $\mathrm{Q}_{10}$ ao redor de 2,0, como é o caso de pimentões inteiros $\left(\mathrm{Q}_{10}=1,9\right)$ ou fatiados $\left(\mathrm{Q}_{10}=2,0\right)$.

Nesta mesma faixa de temperatura, 0 a $10^{\circ} \mathrm{C}$, valores de $\mathrm{Q}_{10}$ ao redor de 16 e 134 são encontrados na literatura, como nos casos, respectivamente, da respiração de fatias de nectarinas parcialmente maduras e da produção de etileno de fatias desta mesma fruta, no estádio “de vez” (Gorny et al.,1998). 


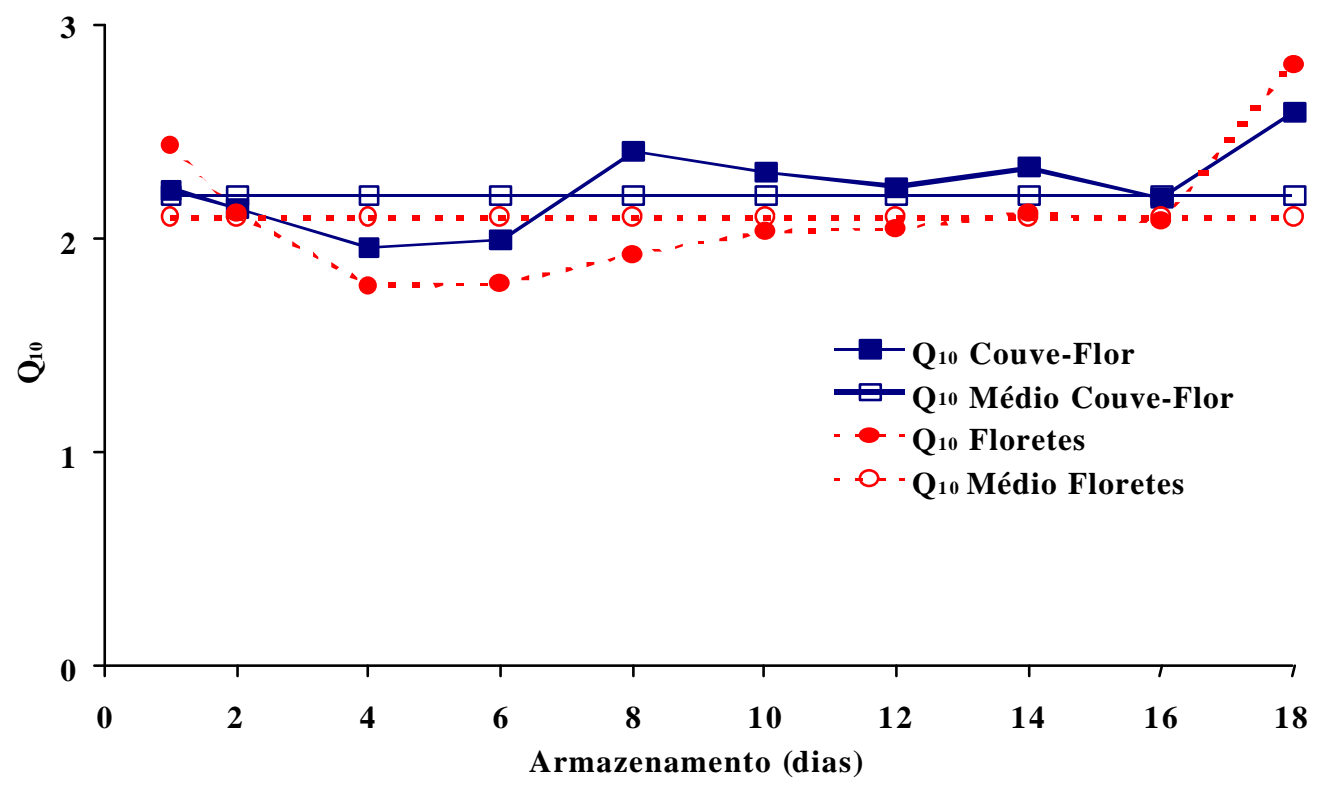

Figura 2 - Valores do quociente de temperatura $\left(\mathrm{Q}_{10}\right)$ para couve-flor e floretes

\subsubsection{Taxas respiratórias de rúculas e de folhas de rúculas}

Próximo a $0^{\circ} \mathrm{C}$, temperatura ideal para armazenamento de hortaliças folhosas (Kasmire \& Cantwell, 1992a), observa-se que as rúculas (folhas unidas pela base) e suas folhas (minimamente processadas) possuem um comportamento respiratório semelhante ao da couve-flor (Figura 3).

Assim, a $1^{\circ} \mathrm{C}$, há um leve e constante decréscimo de $25,08 \mathrm{mg} \mathrm{CO}_{2} \cdot \mathrm{kg}^{-1} \cdot \mathrm{h}^{-1} \mathrm{a}$ $11,04 \mathrm{mg} \mathrm{CO} \cdot \mathrm{Cg}^{-1} \cdot \mathrm{h}^{-1}$ para as rúculas, e de $21,02 \mathrm{mg} \mathrm{CO} \cdot \mathrm{kg}^{-1} \cdot \mathrm{h}^{-1}$ a $10,44 \mathrm{mg} \mathrm{CO} \cdot \mathrm{Cg}^{-}$ ${ }^{1} \cdot \mathrm{h}^{-1}$ para as folhas, não unidas pela base. Taxas de respiração semelhantes às primeiras foram encontradas por Peiris a al. (1997) que relatam níveis de 21,1 $\pm 5,3 \mathrm{mg} \mathrm{CO}_{2} \cdot \mathrm{kg}^{-}$ ${ }^{1} \cdot \mathrm{h}^{-1}$ para rúculas armazenadas a $0^{\circ} \mathrm{C}$.

Piergiovanni et al. (1999) observaram níveis de 63,07 $\pm 2.2 \mathrm{mg} \mathrm{CO} 2 \cdot \mathrm{kg}^{-1} \cdot \mathrm{h}^{-1}$ para rúculas minimamente processadas a $7^{\circ} \mathrm{C}$. Taxas de respiração como estas foram observadas nas condições do presente experimento, após o $6^{\circ}$ dia de manutenção de rúculas minimamente processadas a $11^{\circ} \mathrm{C}$. $\mathrm{O}$ fato das rúculas italianas terem sido lavadas 
e secas em condições de ar ambiente, talvez, tenha contribuído para esta diferença em sua taxa respiratória.

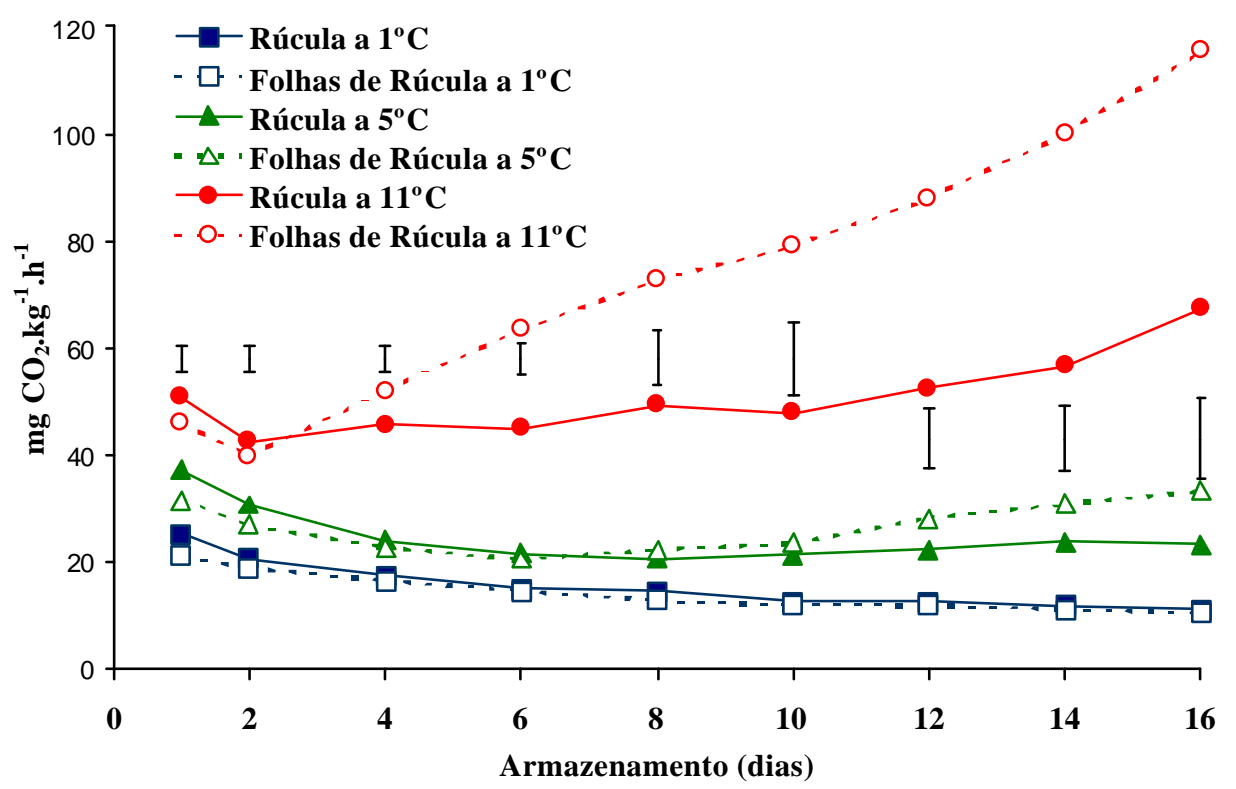

Figura 3 - Respiração de rúculas (unidas pela base) e folhas (minimamente processadas) a 1,5 e $11^{\circ} \mathrm{C}$, em mg $\mathrm{CO}_{2} \cdot \mathrm{kg}^{-1} \cdot \mathrm{h}^{-1}$. Barras na vertical indicam a diferença mínima significativa (DMS) $(\mathrm{P} \leq 0.05)$.

Mesmo não havendo diferenças significativas, as folhas soltas apresentam taxas respiratórias levemente menores que as rúculas (folhas unidas pela base) durante todo o período de experimentação a $1^{\circ} \mathrm{C}$, nos primeiros 6 dias a $5^{\circ} \mathrm{C}$ e 2 dias a $11^{\circ} \mathrm{C}$. Mais uma vez, o que era esperado não ocorreu com as rúculas. Geralmente, os cortes provocados pelo processamento mínimo induzem a maior taxa de respiração (Rolle \& Chism, 1987). Porém, Watada et al. (1996) citam vários exemplos de hortaliças minimamente processadas com níveis respiratórios abaixo daqueles das hortaliças que lhes deram origem, como exemplos: abobrinha italiana, morangos e melões. Estes dados mostram que isto é válido para estes produtos quando às temperaturas de $0^{\circ}, 5^{\circ}$ e $10^{\circ} \mathrm{C}$. A $20^{\circ} \mathrm{C}$, há a inversão, ou seja, as taxas respiratórias destas hortaliças minimamente processadas passam a ser bem maiores que as das inteiras. 
Com as rúculas, esta inversão também ocorreu já a partir do $6^{\circ}$ dia de armazenamento a $5^{\circ} \mathrm{C}$, contudo, sem haver diferenças significativas. A $11^{\circ} \mathrm{C}$, as taxas respiratórias das rúculas minimamente processadas passaram a ser significativamente superiores às das inteiras, a partir do $4^{\circ}$ dia, e nos $14^{\circ}$ e $16^{\circ}$ dias, as diferenças foram de quase o dobro.

Esta alteração nas taxas respiratórias das rúculas ocorreu a partir do momento em que mudavam de coloração verde-escura para verde-clara e amarela. E, neste estádio, as rúculas minimamente processadas amareleciam mais rapidamente que as inteiras. A partir do $6^{\circ}$ dia a $5^{\circ} \mathrm{C}$, já se observava leve presença de pigmentação amarela em algumas folhas minimamente processadas. A $11^{\circ} \mathrm{C}$, o amarelecimento já havia iniciado no $2^{\circ}$ dia, sendo que no $6^{\circ}$ dia, todas já estavam muito amarelas, comprometendo seriamente sua qualidade para o consumo. Por outro lado, a $1^{\circ} \mathrm{C}$, as rúculas e folhas permaneceram verdes durante todo o período de 16 dias. Toivonen (1997) relata uma respiração decrescente para brócolos durante 17 dias de armazenamento a $1^{\circ} \mathrm{C}$ e que a perda de coloração verde e manifestação da coloração amarela esteva altamente correlacionada com a taxa de respiração desta hortaliça. Tian et al. (1994) confirmam estes resultados, afirmando que a respiração de brócolos e de floretes aumenta à medida que amarelecem.

Em rúculas, o amarelecimento é um dos indicadores de sua perda de qualidade e, no presente experimento, veio acompanhado pela presença de pústulas de microrganismos. Estes talvez tenham sido os responsáveis pelas elevadas taxas de respiração destas hortaliças, uma vez que fungos e bactérias fitopatogênicas podem aumentar a taxa de respiração (Salunke et al., 1991).

Mais uma vez, observa-se que a temperatura foi o fator que mais influenciou a vida-de-prateleira de hortaliças minimamente processadas.

\subsubsection{Q Q para rúculas e folhas de rúculas}

Dentro da faixa de temperatura estudada, de 1 a $11^{\circ} \mathrm{C}$, o quociente de temperatura variou muito, ou seja, de 2,02 a 6,09, para rúculas inteiras e de 2,19 a 11,04, para as 
rúculas minimamente processadas, em folhas (Figura 4). De modo geral, o valor médio de $\mathrm{Q}_{10}$ para as rúculas inteiras situou-se ao redor de 3.54 e para as folhas, em 5,74.

Esta grande variação ocorreu devido à alta perecibilidade desta hortaliça a $11^{\circ} \mathrm{C}$, principalmente, em sua forma minimamente processada.

Considerando-se os 4 primeiros dias, quando as rúculas inteiras ou em folhas, mesmo a $11^{\circ} \mathrm{C}$, permaneciam com coloração verde e, portanto, ainda comercializáveis, o quociente de temperatura esteve entre 2,02 a 2,63 para as inteiras e 2,19 a 3,16, para as folhas soltas. Valores estes que indicam velocidades de respiração duplicando ou triplicando quando estes produtos são armazenados a $11^{\circ}$ e não a $1^{\circ} \mathrm{C}$ e, consequientemente, com menor vida-de-prateleira. Níveis de $\mathrm{Q}_{10}$ como estes são encontrados para outras hortaliças (Watada, 1996) e frutas, como a laranja (Rocha et al., 1995).

Porém, quando se comparam os valores médios de $\mathrm{Q}_{10}$ das couves-flores com os de rúculas, verifica-se que aquelas hortaliças, inteiras ou minimamente processadas, são muito menos perecíveis que estas.

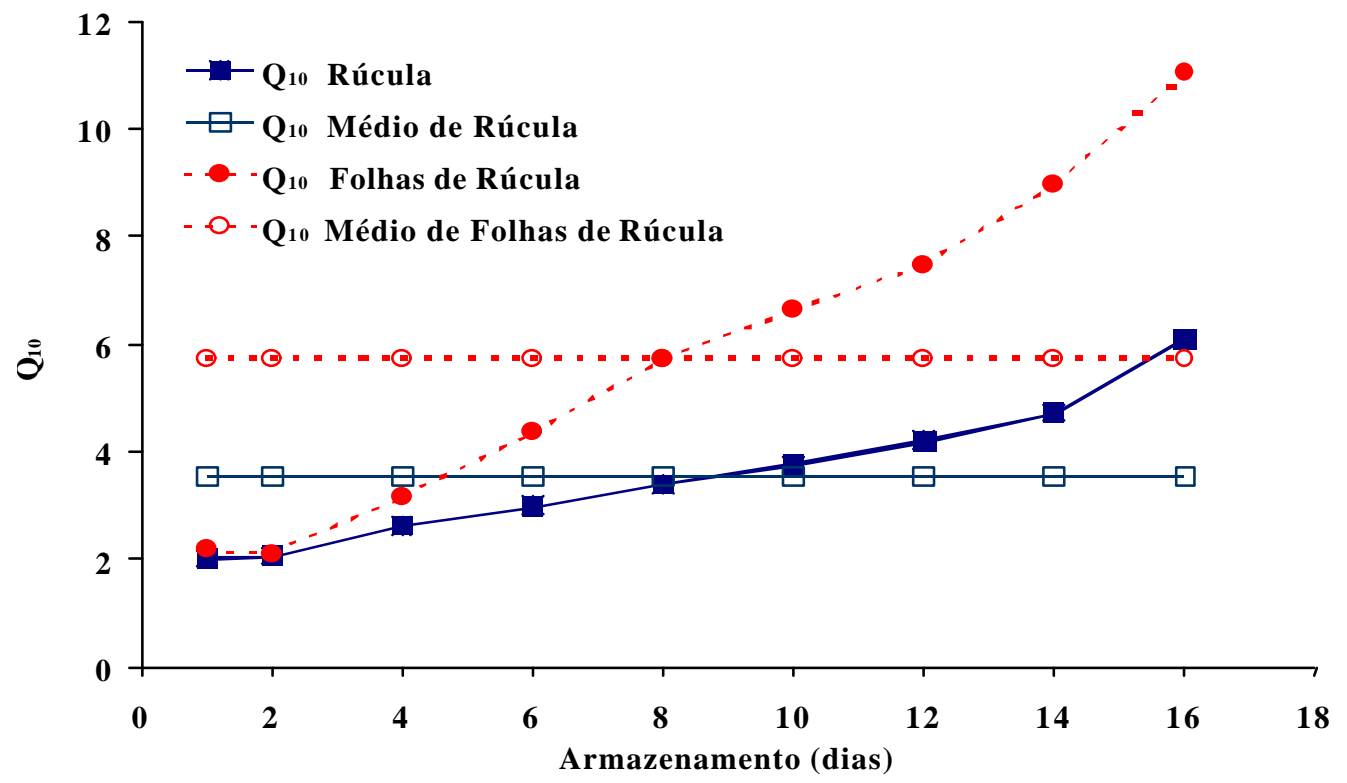

Figura 4 - Valores do quociente de temperatura $\left(Q_{10}\right)$ para rúculas inteiras e minimamente processadas (folhas). 


\subsubsection{Produção de etileno}

Em nenhuma das hortaliças, couves-flores e rúculas, em sua formas inteiras ou minimamente processadas, foram detectadas produções de etileno.

Para couves-flores, os dados deste experimento coincidem com os relatados por Kubo et al. (1990) que também não detectaram produção de etileno desta hortaliça quando armazenada a $25^{\circ} \mathrm{C}$.

Mertens \& Tranggono (1989) observaram que couves-flores armazenadas a 0$1^{\circ} \mathrm{C}$ produziam menos que $0,03 \mu \mathrm{LC}_{2} \mathrm{H}_{4} \cdot \mathrm{kg}^{-1} \cdot \mathrm{h}^{-1}$ e quase $0,1 \mu \mathrm{L} \mathrm{C} \mathrm{C}_{2} \mathrm{H}_{4} \cdot \mathrm{kg}^{-1} \cdot \mathrm{h}^{-1}$, quando armazenadas a $10^{\circ} \mathrm{C}$. Estes níveis de etileno estão abaixo de $0,1 \mu \mathrm{L} \mathrm{C} \mathrm{C}_{2} \mathrm{H}_{4} \cdot \mathrm{kg}^{-1} \cdot \mathrm{h}^{-1}$, a partir de que este regulador de crescimento começa a ser fisiológicamente ativo e, portanto, sem interesse do ponto de vista de fisiologia e tecnologia de pós-colheita (Reid, 1992).

\subsection{Conclusões}

couves-flores e floretes devem ser mantidos a $1^{\circ}$ ou $5^{\circ} \mathrm{C}$, pois nestas temperaturas, suas taxas respiratórias (metabolismos) são menores que a $11^{\circ} \mathrm{C}$;

$>$ o efeito da alta emperatura $\left(11^{\circ} \mathrm{C}\right)$ foi maior no metabolismo de rúculas minimamente processadas, uma vez que respiraram bem mais que as inteiras, a partir do $4^{\circ}$ dia, além de estarem completamente amarelas, no $6^{\circ}$ dia;

$>$ as rúculas inteiras ou minimamente processadas devem ser mantidas a $1^{\circ} \mathrm{C}$, pois, a partir do $6^{\circ}$ dia a $5^{\circ} \mathrm{C}$, elas começam a perder a coloração verde-escura, passando para verde-clara, quase ligeiramente amarelada, podendo passar a amarela a qualquer alteração de temperatura;

quanto ao efeito da temperatura na produção de etileno de couves-flores, floretes, rúculas inteiras ou minimamente processadas, não foi detectada sua presença em qualquer das três temperaturas estudadas. 


\section{INFLUÊNCIA DE EMBALAGENS COM FILMES FLEXÍVEIS NA QUALIDADE DE FLORETES DE COUVES-FLORES}

\section{Resumo}

O presente estudo teve por objetivo avaliar a influência de diferentes filmes flexíveis na qualidade de couve-flor Luna, minimamente processada na forma de floretes, mantidos durante 14 dias em câmara frigorífica a $5^{\circ} \mathrm{C}$ e $85-95 \%$ de umidade relativa. Os materiais de embalagem utilizados foram filme de polietileno de baixa densidade (PEBD), filmes poliolefínicos coextrusados, tipo PD - 941 e Clysar AFG e filmes de policloreto de vinila, PVC esticável, de 12 e $20 \mu \mathrm{m}$, envolvendo bandejas de poliestireno expandido. A embalagem de PD - 941 manteve uma composição gasosa mais próxima da recomendada para couves-flores, ao redor de $2-3 \% \mathrm{O}_{2}$ e $\mathrm{CO}_{2}<5 \%$, embora em nenhuma delas, os floretes apresentassem sabor ou odor estranho, após o cozimento. Mesmo ocorrendo perda de vitamina C, o filme PD - 941 foi o que manteve maiores níveis desta vitamina nos floretes, durante os 14 dias a $5^{\circ} \mathrm{C}$. Pouco ou nenhum efeito das embalagens foi observado no $\mathrm{pH}$, acidez titulável, sólidos solúveis, Luminosidade, Croma, Hue e firmeza dos floretes. Análises microbiológicas revelaram que os floretes apresentaram ausência de Salmonella spp, coliformes fecais (E. coli) abaixo de $10 \mathrm{UFC} / \mathrm{g}$ de floretes, bolores e leveduras abaixo de $10^{2} \mathrm{UFC} / \mathrm{g}$ de floretes e contagem total de coliformes totais menor que $10 \mathrm{UFC/g}$ de produto, à exceção do PVC - $20 \mu \mathrm{m}$ que apresentou $3,1 \times 10^{3} \mathrm{UFC} / \mathrm{g}$ de produto, a partir do $7^{\circ}$ dia. As análises sensoriais revelaram que, à primeira vista, os provadores preferiram os floretes em embalagens com bandejas e não em sacos. Porém, avaliando-se os outros componentes 
de qualidade, observa-se que as embalagens de PD - 941 e PEBD sobressaíram-se sobre as demais, sendo que a PD -941 foi, ainda, ligeiramente superior.

Palavras-chave: Brassica oleracea L. var. botryits L., minimamente processada, atmosfera modificada, características físicas, químicas, fisico-químicas e sensoriais.

\section{Summary}

The objective of this study was to determine the influence of different wrapping films on the quality of Luna cauliflower florets held at $5^{\circ} \mathrm{C}$ and $85-95 \%$ relative humidity for a 14-day period. The films were made from low-density polyethylene film (LDPE), co-extruded polyolefins, such as PD - 941 and Clysar AFG, and 12 and $20 \mu \mathrm{m}$ stretchable polyvinyl chloride (PVC) overwrapping expanded polystyrene trays. The PD - 941 packaging maintained a steady-state gas composition closest to that recommended $\left(2-3 \% \mathrm{O}_{2}\right.$ and $\mathrm{CO}_{2}<5 \%$ ) for the preservation of cauliflower quality, although none of the films resulted in the development of detectable off-flavors in the florets after cooking. Despite some losses, the PD - 941 film also maintained the best level of vitamin $\mathrm{C}$ in the florets during the 14-day period at $5^{\circ} \mathrm{C}$. Little effect of the packaging material was observed on the $\mathrm{pH}$, titratable acidity, soluble solids, color (L, Chroma and Hue) and firmness. No Salmonella spp was detected; yeasts and molds were below $10^{2}$ $\mathrm{CFU} / \mathrm{g}$ for all the packaging films and total and fecal coliform counts were below 10 $\mathrm{CFU} / \mathrm{g}$ with the exception of PVC $-20 \mu \mathrm{m}$, in which the total coliform count reached $3,1 \times 10^{3} \mathrm{CFU} / \mathrm{g}$ as from the $7^{\text {th }}$ day. Initially, the sensory analysis showed that the panelists preferred the florets presented on trays overwrapped with PVC rather than in bags. However, an evaluation of other quality factors revealed the superiority of the LDPE and PD - 941 bags for the florets, and considering the lower vitamin C losses and better internal gas composition obtained with the PD -941 film, this appears to be slightly better than the LDPE film for the preservation of cauliflower floret quality and consequently to extend product shelf-life. 
Key-words: Brassica oleracea L. var. botryits L., fresh-cut, modified atmosphere packaging, quality attributes.

\subsection{Introdução}

A mudança nos padrões de consumo de alimentos, com ênfase na conveniência, na praticidade, na facilidade de preparo ou no estar pronto para ser servido, no frescor, na qualidade e em sua segurança, tem levado a uma crescente comercialização de hortaliças já lavadas, descascadas, cortadas, higienizadas e embaladas, prontas para serem consumidas.

Esta crescente comercialização de hortaliças, com um mínimo de preparo, traz novos desafios à indústria de alimentos que tem que estender ou expandir conhecimentos visando à manutenção da qualidade de produtos muito mais perecíveis do que os inteiros, que lhes deram origem.

A ação física do processamento mínimo induz ou acelera as alterações que ocorrem durante a senescência das hortaliças. Estas alterações ocorrem particularmente nos tecidos adjacentes àqueles que sofreram ferimentos devido ao descascamento ou corte, quando agentes internos, como ácidos e enzimas (hidrolases) são liberados dos vacúolos (WATADA et al., 1990 \& WATADA et al., 1996) e reações metabólicas indesejáveis são iniciadas (escurecimento, respiração acelerada, etc.) ou quando agentes externos, como fungos, bactérias, leveduras começam a se desenvolver naquelas áreas (OSORNIO \& CHAVES, 1998).

Desta forma, várias têm sido as técnicas propostas e utilizadas para minimizar os efeitos maléficos dos danos físicos aos tecidos vegetais.

Além da refrigeração, a própria utilização de embalagens de filmes flexíveis tem grande potencial para retardar várias das alterações que conduzem à rápida senescência e estender a vida-de-prateleira de hortaliças minimamente processadas.

Os filmes poliolefínicos vêm sendo utilizados para embalagens de produtos hortícolas desde 1930, com a função principal de reduzir o processo de transpiração de 
frutas e hortaliças in natura. Daquela época até 1970, vários estudos encorajavam perfurações nos filmes para se evitar o desenvolvimento de atmosferas que pudessem causar danos às frutas e hortaliças. A partir da metade dos anos 70, os interesses começaram a se voltar para a utilização das características de permeabilidade dos filmes poliolefínicos para se desenvolver atmosferas modificadas durante os períodos de armazenamento, transporte e comercialização destes produtos (Prince, 1989).

Desta forma, os filmes de polietileno (PE) e de policloreto de vinila (PVC) têm sido os mais comercialmente utilizados para as hortaliças minimamente processadas: o PE para a confecção de sacos e o PVC, tipo "Magipack", para embalar produtos contidos em bandejas. Porém, os avanços em tecnologias de coextrusão têm permitido o desenvolvimento de novos materiais com maior gama de permeabilidade a gases (OLIVEIRA et al., 1998), resultando em níveis menores de $\mathrm{O}_{2}$ e maiores de $\mathrm{CO}_{2}$ no interior das embalagens.

Ambientes com níveis baixos de $\mathrm{O}_{2}$ e elevados de $\mathrm{CO}_{2}$ geralmente reduzem as taxas de respiração e de produção de etileno, retardam o amolecimento e diminuem a velocidade com que ocorrem as transformações químicas associadas ao amadurecimento e/ou senescência (Kader et al., 1989), além de reduzir as taxas de perda de qualidade e nutricional, como menor perda de vitamina $\mathrm{C}$ em hortaliças mantidas sob baixos níveis de $\mathrm{O}_{2}$ (Weichmann, 1986).

Em atmosferas em equilíbrio em $3 \% \mathrm{O}_{2}$ e $9 \% \mathrm{CO}_{2}$ no interior de embalagens de filmes flexíveis contendo brócolos minimamente processados e mantidos a $20^{\circ} \mathrm{C} / 96 \mathrm{~h}$, Barth et al. (1993b) relatam maior retenção de ácido ascórbico, clorofila e umidade do que naqueles mantidos fora das embalagens; porém, sem diferenças significativas entre os tratamentos em relação à textura e ao crescimento da população de microrganismos aeróbicos.

Em estudo anterior, com brócolos minimamente processados, porém mantidos sob refrigeração a $10^{\circ} \mathrm{C}$ por $96 \mathrm{~h}$, Barth et al (1993a) relatam que, em uma atmosfera de equilíbrio de $10 \% \mathrm{O}_{2}$ e $8 \% \mathrm{CO}_{2}$, os embalados em filmes poliméricos apresentaram maior retenção de ácido ascórbico, umidade, clorofila total e coloração do que os 
mantidos sem embalagem plástica. Porém, as atividades da peroxidase e ascorbatooxidase e textura foram as mesmas para ambos os tratamentos.

Com couves-flores, Ratti et al. (1996) e Artés \& Martinez (1999) trabalharam com elas intactas. Os primeiros determinando modelos para se avaliar taxas de respiração e os últimos avaliando os efeitos de diferentes filmes flexíveis em sua qualidade.

Como a literatura não contempla estudos da influência de filmes flexíveis na qualidade de couves-flores minimamente processadas, na forma de floretes, este foi o objetivo deste estudo.

\subsection{Materiais e métodos}

Couves-flores Luna foram colhidas, nas primeiras horas da manhã, de uma plantação comercial, no município de Sorocaba (SP).

Após a colheita, foram imediatamente transportadas para o Centro de Pesquisa e Desenvolvimento de Hortícolas (FRUTHOTEC), do Instituto de Tecnologia de Alimentos - ITAL, Campinas (SP), onde foram mantidas, por aproximadamente 03 (três) horas, em câmaras frigoríficas a $5 \pm 1^{\circ} \mathrm{C}$ e $90 \pm 5 \%$ de umidade relativa.

No início da tarde do dia da colheita, as couves-flores foram transferidas para

uma área a $16^{\circ} \mathrm{C}$, limpa e higienizada, para serem submetidas às operações de processamento mínimo.

Em um lote, as folhas e os floretes foram separados da couve-flor com o auxílio de facas novas, muito bem afiadas, para que suas bases sofressem os menores danos possíveis. Desta forma, obtiveram-se os floretes que foram utilizados nas operações subseqüentes do processamento mínimo.

Os floretes foram inicialmente lavados em $200 \mathrm{~L}$ de água a $5^{\circ} \mathrm{C}$, contida em uma banheira de aço inoxidável, com capacidade para 500 L. Nesta primeira lavagem, foram retiradas as sujeiras maiores, como qualquer tipo de partícula que pudesse estar aderida aos floretes. 
Em seguida foram novamente lavadas em água a $5^{\circ} \mathrm{C}$, para certificação de que toda a sujeira mais grossa havia sido eliminada.

Com a finalidade de facilitar a remoção de possíveis insetos e complementar a lavagem, os floretes foram imersos, por 30 segundos, em uma solução a 1\% de SUMAD29 ${ }^{\circledR}$. Este produto é um sabão líquido (Divoplus v3-2) apropriado a frutas e hortaliças, tendo como princípio ativo, sabão potássico de ácidos graxos de soja/coco, fabricado pela Diversey Lever - Indústrias Gessy Lever Ltda. Esta solução foi preparada com água previamente resfriada a $5^{\circ} \mathrm{C}$, como toda a água utilizada durante as outras etapas dos processamentos mínimos.

O excesso de sabão líquido dos floretes foi retirado através da imersão destes em água a $5^{\circ} \mathrm{C}$.

Somente, então, é que foram imersos em solução a $0,66 \%$ de SUMAVEG ${ }^{\circledR}(3 \%$ de cloro ativo), por 5 minutos, com o intuito de sanitização. Este produto tem como princípio ativo o Dicloro-S-Triazinatriona Sódica Diidratada e é fabricado pela Diversey Lever - Indústrias Gessy Lever Ltda.

Finalmente, os floretes foram colocados em saquinhos de malha de fibra sintética, para serem centrifugados por 30 segundos, em equipamento apropriado para produtos minimamente processados, "AngeloPo", de fabricação italiana, com 750 giros/minuto. Os saquinhos permitem a livre passagem de água do produto para a centrífuga e têm a finalidade de protegê-lo de possíveis danos físicos durante a operação de centrifugação.

Após, os floretes foram selecionados, padronizados quanto ao tamanho e ausência de defeitos e pesados, de forma a se obter lotes de aproximadamente $300 \mathrm{~g}$, nos seguintes sistemas de embalagens:

a) sacos plásticos de filme de polietileno de baixa densidade (PEBD), de $270 \times 180$ $\mathrm{mm}$, com termossoldagem feita em uma seladora por impulso elétrico (Haramura);

b) sacos plásticos de filme poliolefínico coextrusado, tipo PD-941, fabricado pela Cryovac, de 270 x 180 mm, com termossoldagem feita em seladora Haramura;

c) sacos plásticos de filme poliolefínico coextrusado, tipo Clysar AFG, fabricado pela DuPont, de 270 x 180 mm, com termossoldagem feita em seladora Haramura; 
d) filme de policloreto de vinila - PVC esticável, tipo OMNI-AM, fabricado pela Goodyear, envolvendo bandejas de poliestireno expandido (210 x 140 x $20 \mathrm{~mm}$ ), com termossoldagem do filme sob a bandeja feita em seladora, dotada de chapa aquecida (Ipeal);

e) filme de policloreto de vinila - PVC esticável, tipo OMNI-AZ, fabricado pela Goodyear, envolvendo bandejas de poliestireno expandido (210 x 140 × $20 \mathrm{~mm}$ ), com termossoldagem do filme sob a bandeja feita em seladora Ipeal.

As características dos sistemas de embalagens estão apresentadas na Tabela 1.

Tabela 1. Características dos sistemas de embalagens utilizados para os floretes.

\begin{tabular}{lcccc}
\hline \multicolumn{1}{c}{ Embalagem } & $\begin{array}{c}\text { Espessura } \\
(\boldsymbol{\mu} \mathbf{m})\end{array}$ & \multicolumn{2}{c}{ Taxas de Permeabilidade } & $\begin{array}{c}\text { Área de Permeação }^{\mathbf{O}_{\mathbf{2}}} \\
\mathbf{C O}_{\mathbf{2}}\end{array}$ \\
\hline PEBD & 25 & 8.576 & 43.383 & 450 \\
PD - 941 & 21 & 12.625 & 24.485 & 450 \\
CLYSAR AFG & 15 & 12.232 & 52.945 & 450 \\
PVC - OMNI-M & 12 & 9.032 & 67.380 & 730 \\
PVC - OMNI-AZ & 20 & 8.212 & 61.260 & 730 \\
\hline
\end{tabular}

${ }^{1}$ Determinadas sob Condições Normais de Temperatura e Pressão (CNTP) e expressas $\mathrm{em} \mathrm{cm}^{3} / \mathrm{m}^{2} /$ dia.

Após a embalagem, os floretes foram colocados em câmara frigorífica a $5 \pm 1^{\circ} \mathrm{C}$ e $85-95 \%$ de umidade relativa.

Aos $0,3,7,10$ e 14 dias de permanência dos floretes sob refrigeração, 04 embalagens de cada um dos 05 tratamentos foram submetidas às seguintes análises:

a) composição gasosa no interior das embalagens: leitura direta de $\mathrm{O}_{2}$ e $\mathrm{CO}_{2}$ através de analisador PBI Dansensor, modelo Combi Check 9800-1, sendo que os resultados estão expressos em percentagem;

b) pH: determinado no suco extraído de floretes através de centrífuga Walita, com leitura direta em pHmetro digital Mettler Toledo, modelo 320, de acordo com metodologia descrita em Carvalho et al. (1990); 
c) acidez titulável: determinada potenciometricamente no suco previamente preparado, seguindo metodologia descrita em Carvalho et al.(1990) e expressando os resultados em $\mathrm{g}$ de ácido málico/100 g de amostra;

d) sólidos solúveis: determinados no suco de floretes, com leitura direta em refratômetro manual ATAGO e resultados expressos em ${ }^{\circ}$ Brix (Carvalho et al., 1990);

e) vitamina $\mathbf{C}$ : determinada por titulometria, de acordo com metodologia descrita em Carvalho et al. (1990), e os resultados expressos em mg de ácido ascórbico por $100 \mathrm{~g}$ de amostra;

f) coloração dos floretes: leitura direta de L (Luminosidade), C (Croma) e H (Hue) realizada em 04 pontos de cada um dos 03 floretes que foram retirados de cada uma das 04 repetições de embalagens, por tratamento, perfazendo um total de 48 leituras por tratamento em cada dia de análise;

c) firmeza dos floretes: determinada por leitura direta da força máxima de cisalhamento em floretes unitários $(20-30 \mathrm{~g}$ ), através de texturômetro TAXT-2i (célula de $25 \mathrm{~kg}$ ) equipado com ponteira tipo faca, sendo as velocidades de pré-teste, teste e pós-teste, respectivamente, de 5,1 e $5 \mathrm{~mm} / \mathrm{s}$, a distância de penetração de $10 \mathrm{~mm}$ e os resultados em kg representam a média de 12 floretes por tratamento;

g) análises microbiológicas: $25 \mathrm{~g}$ de floretes foram homogeneizados em "Stomacher" por 1 minuto em $225 \mathrm{~mL}$ de tampão fosfato $\mathrm{pH}$ 7,0, preparando-se diluições decimais sucessivas para a realização dos seguintes exames: i) contagem total de coliformes totais e de coliformes fecais Escherichia coli), em PETRIFILM 6410, da 3M; ii) contagem total de bolores e leveduras, através do plaqueamento em superfície , utilizando-se o Ágar Dicloram Rosa de Bengala Cloranfenicol (DRBC); iii) Salmonella spp determinada somente no primeiro dia, através do método rápido TECRA UNIQUE; todos realizados conforme metodologias descritas por Silva et al.(2001).

h) análise sensorial: uma equipe de 10 provadores não-treinados avaliou os seguintes atributos de qualidade do produto: aparência geral (conjunto floretes + embalagem), odor estranho (na abertura das embalagens), qualidade geral dos floretes, murchamento, deterioração, escurecimento, textura, sabor e odor estranhos (Figura 5). Para a avaliação dos 3 últimos atributos, os floretes eram cozidos por 5 minutos antes de serem servidos. 


\section{FICHA DE AVALIAÇÃO}

Experimento: Influência de embalagens com filmes flexíveis na qualidade de floretes de couves-flores.

Provador:

Data:

Instruções: Por favor, dê notas de acordo com as escalas descritas abaixo para cada um dos atributos constantes no seguinte quadro:

\begin{tabular}{|l|c|c|c|c|c|}
\hline \multirow{2}{*}{ ATRIBUTO } & \multicolumn{5}{c|}{ TRATAMENTOS } \\
\cline { 2 - 6 } & $\mathbf{1}$ & $\mathbf{2}$ & $\mathbf{3}$ & $\mathbf{4}$ & $\mathbf{5}$ \\
\hline Aparência geral (embalagem + floretes) & & & & & \\
\hline Odor estranho (ao abrir embalagem) & & & & & \\
\hline Qualidade geral dos floretes & & & & & \\
\hline Murchamento & & & & & \\
\hline Deterioração & & & & & \\
\hline Escurecimento & & & & & \\
\hline Textura & & & & & \\
\hline Sabor estranho & & & & & \\
\hline Odor estranho & & & & & \\
\hline
\end{tabular}

ESCALAS DE NOTAS

Aparência geral

1. Péssima

2. Ruim

3. Regular

4. Boa

5. Excelente

Odor estranho

1 Ausente

2. Leve

3. Moderado

4. Intenso

5. Muito intenso

Qualidade geral

1. Péssima

2. Ruim

3. Regular

4. Boa

5. Excelente
Murchamento

1 Ausente

2. Leve

3. Moderado

4. Intenso

5. Muito intenso

Deterioração

1 Ausente

2. Leve

3. Moderada

4. Intensa

5. Muito intensa

Escurecimento

1 Ausente

2. Leve

3. Moderado

4. Intenso

5. Muito intenso
Textura

1. Macia

2. Pouco macia

3. Ligeiramente dura

4. Moderadamente dura

5. Dura

\section{Sabor estranho}

1 Ausente

2. Leve

3. Moderado

4. Intenso

5. Muito intenso

Obs.: Notas intermediárias podem ser utilizadas, quando conveniente.

Figura 5 - Ficha de avaliação e escalas de notas utilizadas para análise sensorial dos floretes de couve-flor em diferentes embalagens. 
O delineamento utilizado foi o inteiramente casualizado com quatro repetições para cada tratamento. Os dados, com exceção dos microbiológicos, foram submetidos à análise de variância e as médias comparadas pelo teste Tukey a 5\% de probabilidade, utilizando-se o programa estatístico SAS (SAS Institute, Inc., 1996).

\subsection{Resultados e discus são}

\subsubsection{Composição gasosa no interior das embalagens}

As concentrações de oxigênio $\left(\mathrm{O}_{2}\right)$ e de gás carbônico $\left(\mathrm{CO}_{2}\right)$ no interior das embalagens, durante os 14 dias em que os floretes foram mantidos a $5^{\circ} \mathrm{C}$ e $80-90 \%$ de umidade relativa, estão apresentadas nas Figuras 6 e 7, respectivamente.

Os níveis de oxigênio no interior das embalagens de PVC, 12 e $20 \mu \mathrm{m}$, variaram muito durante os 14 dias de armazenamento a $5^{\circ} \mathrm{C}$. No segundo dia de análise, 3 dias a $5^{\circ} \mathrm{C}$, os teores foram de $0,3 \%$, na de PVC - $12 \mu \mathrm{m}$ e de $0,2 \%$, na de PVC $-20 \mu \mathrm{m}$. Após,

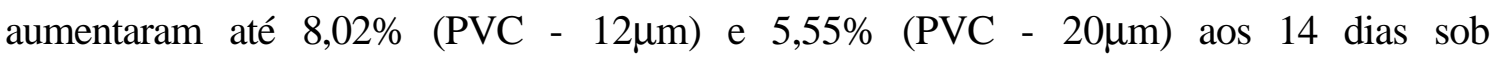
refrigeração.

Por outro lado, as embalagens de PEBD, CLYSAR AFG e PD - 941 apresentaram teores de $\mathrm{O}_{2}$ bem mais estáveis do $3^{\circ}$ ao $14^{\circ}$ dia a $5^{\circ} \mathrm{C}$. Desta forma, as concentrações de equilíbrio de $\mathrm{O}_{2}$ no interior das embalagens foram de: 0,22 a $0,55 \%$ (PEBD); 16,5 a 17,94\% (CLYSAR AFG) e 1,18 a 3,63\% (PD - 941).

A Figura 7 mostra que todas as embalagens propiciaram aos floretes melhor concentração de equilíbrio de $\mathrm{CO}_{2}$ do que de $\mathrm{O}_{2}$. A razão disto pode ser explicada porque as embalagens alternavam momentos de intensa depleção de ar com outros em que estavam normais. Nos períodos de falta de oxigênio, este gás permeava do ambiente para o interior das embalagens, fazendo com que voltassem ao normal.

Entre o $3^{\circ}$ e $14^{\circ}$ dia a $5^{\circ} \mathrm{C}$, o nível de $\mathrm{CO}_{2}$ no interior da CLYSAR AFG variou de $3,6 \%$ a $2,3 \%$ e, na PD - 941 , de $4,58 \%$ a $3,13 \%$. 


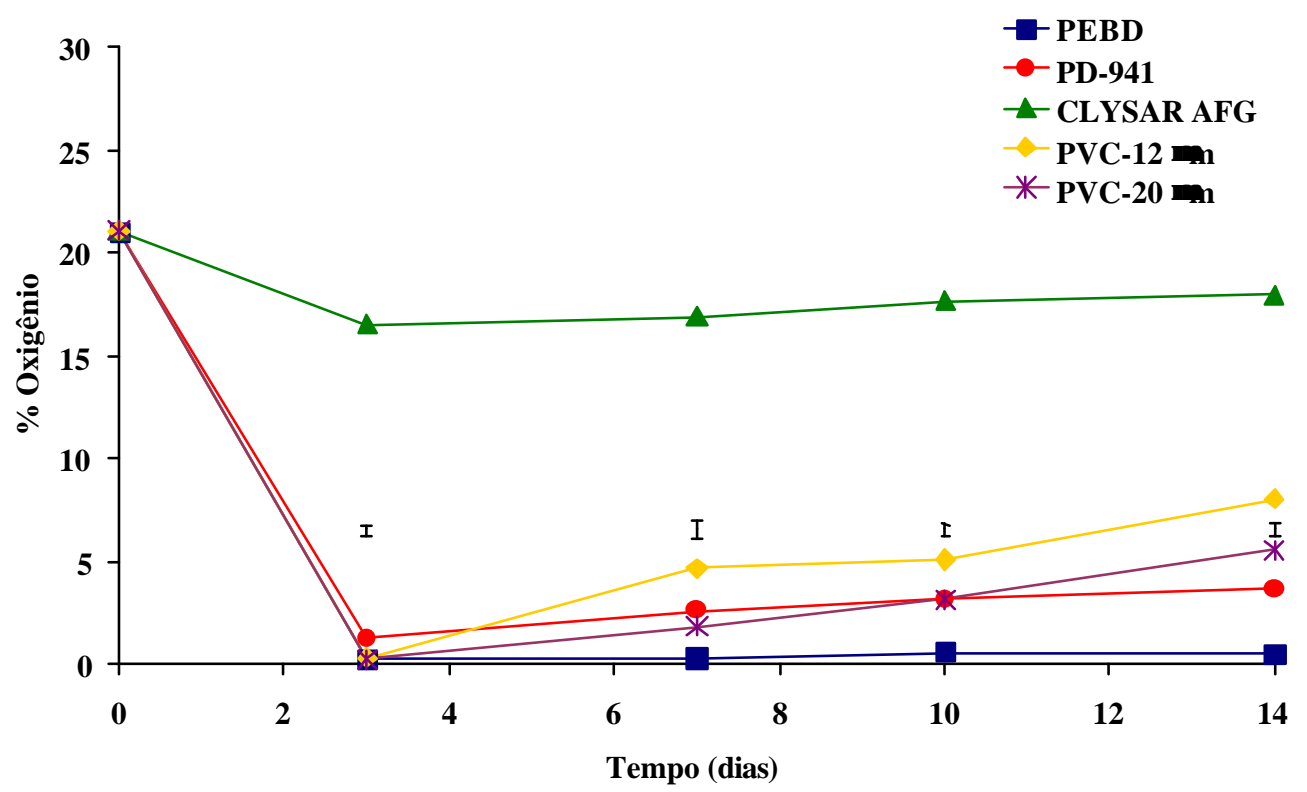

Figura 6 - Alteração do teor de oxigênio no interior das embalagens de floretes mantidos a $5^{\circ} \mathrm{C}$ e $85-95 \%$ de umidade relativa. Barras na vertical indicam a diferença mínima significativa (DMS) $(\mathrm{P} \leq 0,05)$.

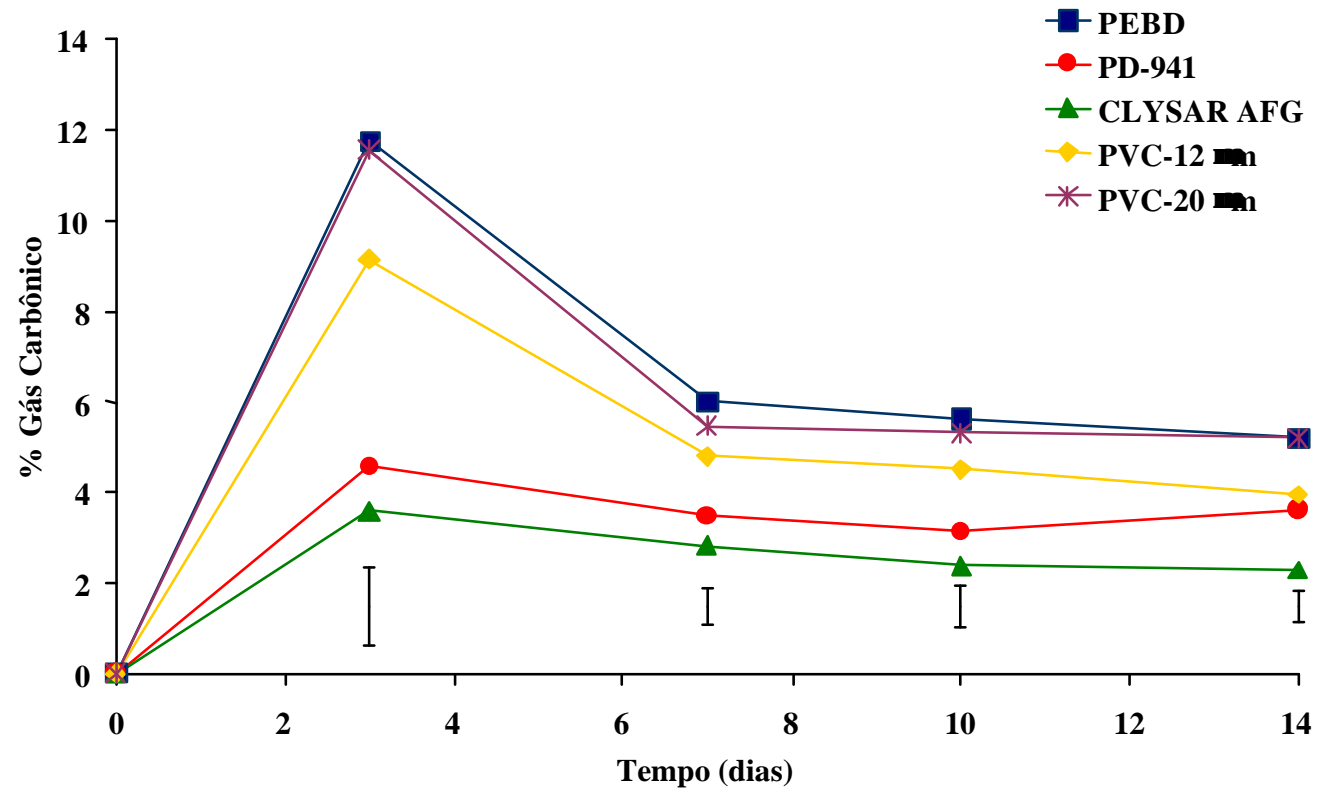

Figura 7 - Alteração do teor de gás carbônico no interior das embalagens de floretes mantidos a $5^{\circ} \mathrm{C}$ e $85-95 \%$ de umidade relativa. Barras na vertical indicam a diferença mínima significativa (DMS) $(\mathrm{P} \leq 0,05)$. 
Para as embalagens de PEBD, PVC - $12 \mu \mathrm{m}$ e PVC $-20 \mu \mathrm{m}$, as atmosferas de equilíbrio foram observadas mais tarde. Do $7^{\circ}$ ao $14^{\circ}$ dia, o teor de $\mathrm{CO}_{2}$ na PEBD oscilou entre $6,0 \%$ e 5,2\%; no PVC $-12 \mu \mathrm{m}$, entre $4,8 \%$ a 3,95\% e, no PVC $-20 \mu \mathrm{m}$, entre $5,45 \%$ a $5,2 \%$. No $3^{\circ}$ dia a $5^{\circ} \mathrm{C}$, atingiram níveis bem maiores, de $11,73 \%, 9,13 \%$ e $11,53 \%$, respectivamente.

Atmosferas que entram em equilíbrio em um período menor são relatadas para brócolos. Barth et al.(1993a) observaram níveis de equilíbrio de $10 \% \quad \mathrm{O}_{2}$ e $8 \% \mathrm{CO}_{2}$ atingidos em 48 horas do início de armazenamento a $10^{\circ} \mathrm{C}$. Em outro estudo, com brócolos de outro cultivar, porém embalados em filmes semelhantes ao do experimento anterior, Barth et al. (1993b) mostraram que, após $24 \mathrm{~h}$ a $20^{\circ} \mathrm{C}$, níveis de $2 \% \mathrm{O}_{2}$ e $10 \%$ $\mathrm{CO}_{2}$ foram encontrados nas embalagens, os quais entraram em equilíbrio a $3 \% \mathrm{O}_{2}$ e $9 \%$ $\mathrm{CO}_{2}$, em 48 horas.

Com couves-flores inteiras em embalagens de PVC e PEBD de diferentes espessuras, Artés \& Martínez. (1999) encontraram atmosferas de equilíbrio entre 15 a $17 \% \mathrm{O}_{2}$ e 1,5 a $3 \% \mathrm{CO}_{2}$, ao final de 7 dias a $1,5^{\circ} \mathrm{C}$.

Níveis menores que 15 a $17 \% \mathrm{O}_{2}$ são recomendados para melhor manutenção da qualidade de couves-flores. Geralmente, o que se encontra na literatura são atmosferas contendo ao redor de $2-3 \% \mathrm{O}_{2}$ e não mais que $5 \% \mathrm{CO}_{2}$ (Mertens \& Tranggono,1989) e (Vallespir,1993). De acordo com esta última pesquisadora, se a concentração de $\mathrm{O}_{2}$ for menor que $2 \%$ e/ou do $\mathrm{CO}_{2}$ maior que $5 \%$, distúrbios podem aparecer na inflorescência, caracterizados por um forte odor desagradável e perda de consistência, após o cozimento.

Das embalagens testadas no presente experimento, a PD - 941 parece atender à especificação de manter uma atmosfera próxima a $2-3 \% \mathrm{O}_{2}$ e $\mathrm{CO}_{2}<5 \%$. Embora em termos de $\mathrm{O}_{2}$, o filme $\mathrm{PD}$ - 941 não difira $(\mathrm{P} \leq 0,05)$ do $\mathrm{PVC}-20 \mu \mathrm{m}$ durante quase todos os 14 dias a $5^{\circ} \mathrm{C}$, o PVC apresenta níveis de $\mathrm{CO}_{2}$ bem acima do recomendado para couve-flor. Por outro lado, o filme CLYSAR AFG mantém níveis de $\mathrm{CO}_{2}$ iguais ao do $\mathrm{PD}$ - 941, porém, as concentrações de $\mathrm{O}_{2}$ são muito maiores. 


\subsection{2 $\mathrm{pH}$ e acidez titulável}

As Figuras 8 e 9 e as Tabelas 2 e 3 mostram as médias dos valores de $\mathrm{pH}$ e acidez titulável dos floretes nas embalagens, mantidos a $5^{\circ} \mathrm{C}$, por 14 dias.

$\mathrm{O} \mathrm{pH}$ dos floretes não foi significativamente influenciado pelas embalagens até o $7^{\circ}$ dia a $5^{\circ} \mathrm{C}$. Porém, no $10^{\circ}$ dia, aqueles embalados em PEBD apresentaram valores de pH iguais aos dos contidos em PD - 941 e superiores aos dos demais tratamentos. No $14^{\circ}$ dia, o $\mathrm{pH}$ dos floretes em PVC - $20 \mu \mathrm{m}$ igualou-se aos dos sacos de PD - $941 \mathrm{e}$ PEBD (Figura 8 e Tabela 2).

No geral, o pH dos floretes em PEBD permaneceu inalterado durante os 14 dias a $5^{\circ} \mathrm{C}$; os em Clysar AFG e PVC - $12 \mu \mathrm{m}$ apresentaram leve queda e os em PD - $941 \mathrm{e}$ PVC - $20 \mu \mathrm{m}$ oscilaram bastante. Estes últimos, embora tenham sido os que mais alternaram em valores para baixo e para cima, estatisticamente, não apresentaram diferenças ao longo do período de armazenamento a $5^{\circ} \mathrm{C}$.

Os aumentos e diminuições nos valores de $\mathrm{pH}$ não corresponderam aos respectivos decréscimos e acréscimos nos valores de acidez titulável pela associação de dois fatores. Primeiro, devido à faixa estreita de variação do $\mathrm{pH}(6,41-6,63)$ e da acidez titulável $(0,09$ a 0,13$)$ e, segundo, porque, muitas vezes, na determinação desta, a titulação é encerrada em valor próximo e não exatamente $\mathrm{pH}=8,1$.

Desta forma, nos $7^{\circ}$ e $10^{\circ}$ dias a $5^{\circ} \mathrm{C}$, a acidez dos floretes variou entre as embalagens, mas voltou a ser igual no $14^{\circ}$ dia.

Durante os 14 dias, os floretes em PD - 941 e em Clysar AFG não tiveram alterada sua acidez; houve um leve decréscimo, no $14^{\circ}$ dia, na acidez dos floretes mantidos em PEBD e o PVC provocou oscilações maiores nos teores de acidez de seus floretes.

Artés \& Martínez (1999) observaram pequena ou nenhuma mudança nos valores de acidez titulável para couves-flores mantidas a $1,5^{\circ} \mathrm{C}$, exceção para as embaladas em PEBD $20 \mu \mathrm{m}$ que tiveram sua acidez aumentada $(0,10$ a 0,16$)$. Por outro lado, houve uma significativa redução do $\mathrm{pH}$ para as couves-flores das 6 embalagens estudadas. 


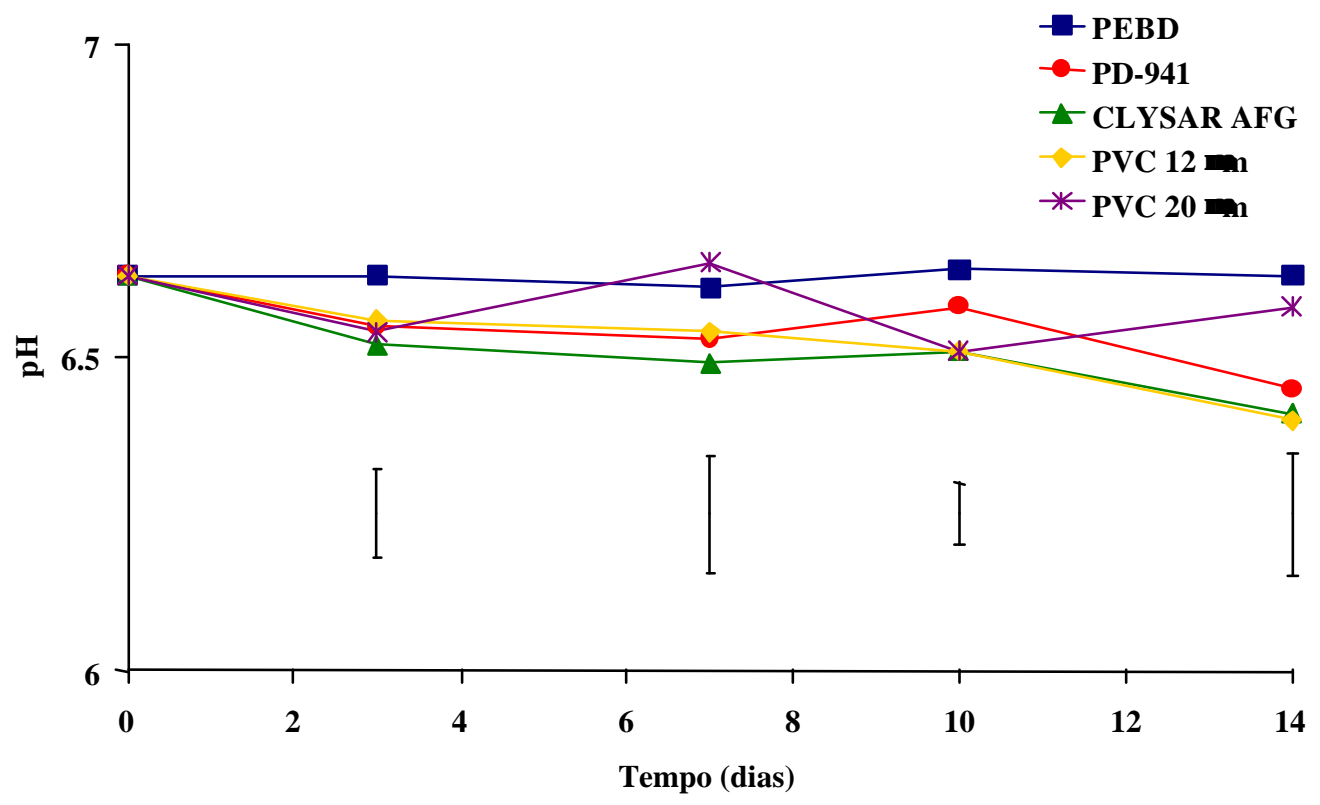

Figura $8-\mathrm{pH}$ dos floretes nas diferentes embalagens, mantidos a $5^{\circ} \mathrm{C}$ e $85-95 \%$ de umidade relativa. Barras na vertical indicam a diferença mínima significativa (DMS) $(\mathrm{P} \leq 0,05)$.

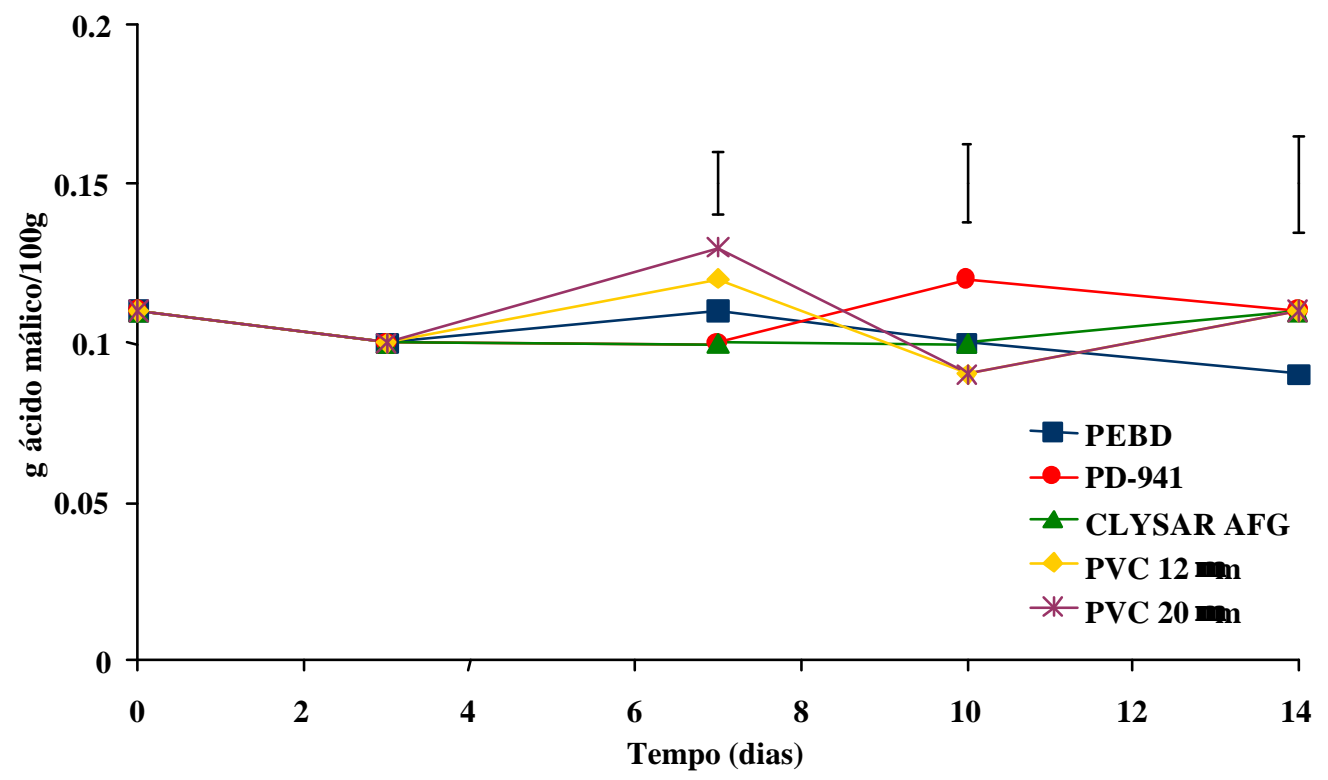

Figura 9 - Acidez titulável dos floretes nas diferentes embalagens, mantidos a $5^{\circ} \mathrm{C}$ e 85 95\% de umidade relativa. Barras na vertical indicam a diferença mínima significativa (DMS) $(\mathrm{P} \leq 0,05)$. 
Tabela 2. $\mathrm{pH}$ de floretes em diferentes embalagens, mantidos a $5^{\circ} \mathrm{C}$ e $85-95 \%$ de umidade relativa.

\begin{tabular}{|c|c|c|c|c|c|c|}
\hline \multirow{2}{*}{ Tratamentos } & \multicolumn{6}{|c|}{$\mathrm{pH}$} \\
\hline & 0 dia & 3 dias & 7 dias & 10 dias & 14 dias & C.V. (\%) \\
\hline PEBD & 6,63 a $A$ & 6,63 a $A$ & 6,61 a $A$ & 6,64 a $A$ & 6,63 a $A$ & 1,09 \\
\hline PD - 941 & 6,63 a $A$ & 6,55 a $\mathrm{AB}$ & 6,53 a $\mathrm{AB}$ & $6,58 \mathrm{ab} A$ & $6,45 \mathrm{ab} B$ & 0,9 \\
\hline CLYSAR AFG & 6,63 a $A$ & 6,52 a $\mathrm{AB}$ & 6,49 a $\mathrm{AB}$ & $6,51 \mathrm{~b} \mathrm{AB}$ & $6,41 \mathrm{~b} \mathrm{~B}$ & 1,08 \\
\hline $\mathrm{PVC}-12 \mu \mathrm{m}$ & 6,63 a $A$ & 6,56 a $A$ & 6,54 a $A$ & $6,51 \mathrm{~b} \mathrm{AB}$ & $6,40 \mathrm{~b} B$ & 0,9 \\
\hline $\mathrm{PVC}-20 \mu \mathrm{m}$ & 6,63 a $A$ & 6,54 a $A$ & 6,65 a $A$ & $6,51 \mathrm{~b} \mathrm{~A}$ & $6,58 \mathrm{ab} A$ & 1,75 \\
\hline C.V. $(\%)$ & - & 0,98 & 1,29 & 0,69 & 1,38 & \\
\hline
\end{tabular}

Médias seguidas da mesma letra minúscula na coluna e maiúscula na linha não diferem entre si, pelo teste de Tukey a 5\% de probabilidade.

Tabela 3. Acidez titulável de floretes em diferentes embalagens, mantidos a $5^{\circ} \mathrm{C}$ e 85 95\% de umidade relativa.

\begin{tabular}{lrrrrrc}
\hline \multirow{2}{*}{ Tratamentos } & \multicolumn{5}{c}{ acidez titulável (g de ácido málico/100 g de amostra) } \\
& 0 dia & 3 dias & 7 dias & 10 dias & 14 dias & C.V. (\%) \\
\hline PEBD & 0,11 a A & 0,10 a A & 0,11 ab A & 0,10 ab A & 0,09 a A & 9,21 \\
PD - 941 & 0,11 a A & 0,10 a A & 0,10 b A & 0,12 a A & 0,11 a A & 12,42 \\
CLYSAR AFG & 0,11 a A & 0,10 a A & 0,10 b A & 0,10 ab A & 0,11 a A & 12,54 \\
PVC - 12 $\mu \mathrm{m}$ & 0,11 a AB & 0,10 a B & 0,12 a A & 0,09 b B & 0,11 a AB & 10,12 \\
PVC - 20 $\mu \mathrm{m}$ & 0,11 a AB & 0,10 a B & 0,13 a A & 0,09 b B & 0,11 a AB & 11,07 \\
C.V. $(\%)$ & - & - & 8,03 & 11,07 & 13,12 & \\
\hline
\end{tabular}

Médias seguidas da mesma letra minúscula na coluna e maiúscula na linha não diferem entre si, pelo teste de Tukey a 5\% de probabilidade.

Resultados semelhantes a este foram observados por Osornio \& Chaves (1998) em beterrabas minimamente processadas, nas quais, independentemente da embalagem (PVC ou EVA), o $\mathrm{pH}$ permaneceu quase que constante ao longo de 1 semana de 
armazenamento a $0^{\circ} \mathrm{C}$. Porém, a $4^{\circ} \mathrm{C}$, após uma semana, o $\mathrm{pH}$ decresceu nas hortaliças em EVA, enquanto as do PVC mantiveram seu nível inicial.

Kader (1986) relata aumento de $\mathrm{pH}$ e conseqüentemente decréscimo na acidez de couves-flores, logo após serem submetidas a altas doses $(15-20 \%)$ de $\mathrm{CO}_{2}$, afirmando que não se sabe se o aumento do $\mathrm{pH}$ é somente uma conseqüência dos efeitos do $\mathrm{CO}_{2}$ no metabolismo normal ou uma forma do tecido vegetal reagir contra a ação acidificante do $\mathrm{CO}_{2}$. Como no presente estudo, o nível mais elevado de $\mathrm{CO}_{2}$ foi de 5 a $6 \%$ nas embalagens de PEBD talvez a teoria de IZUMI et al. (1996), de que as oscilações nos valores de $\mathrm{pH}$ estejam relacionadas às de contagem microbiológica, se aplique melhor.

\subsubsection{Sólidos solúveis ( ${ }^{\circ}$ Brix)}

Em nenhum dia de análise, pôde ser notada influência das embalagens no teor de sólidos solúveis ( ${ }^{\circ}$ Brix) de floretes mantidos durante 14 dias a $5^{\circ} \mathrm{C}$ (Figura 10, Tabela 4).

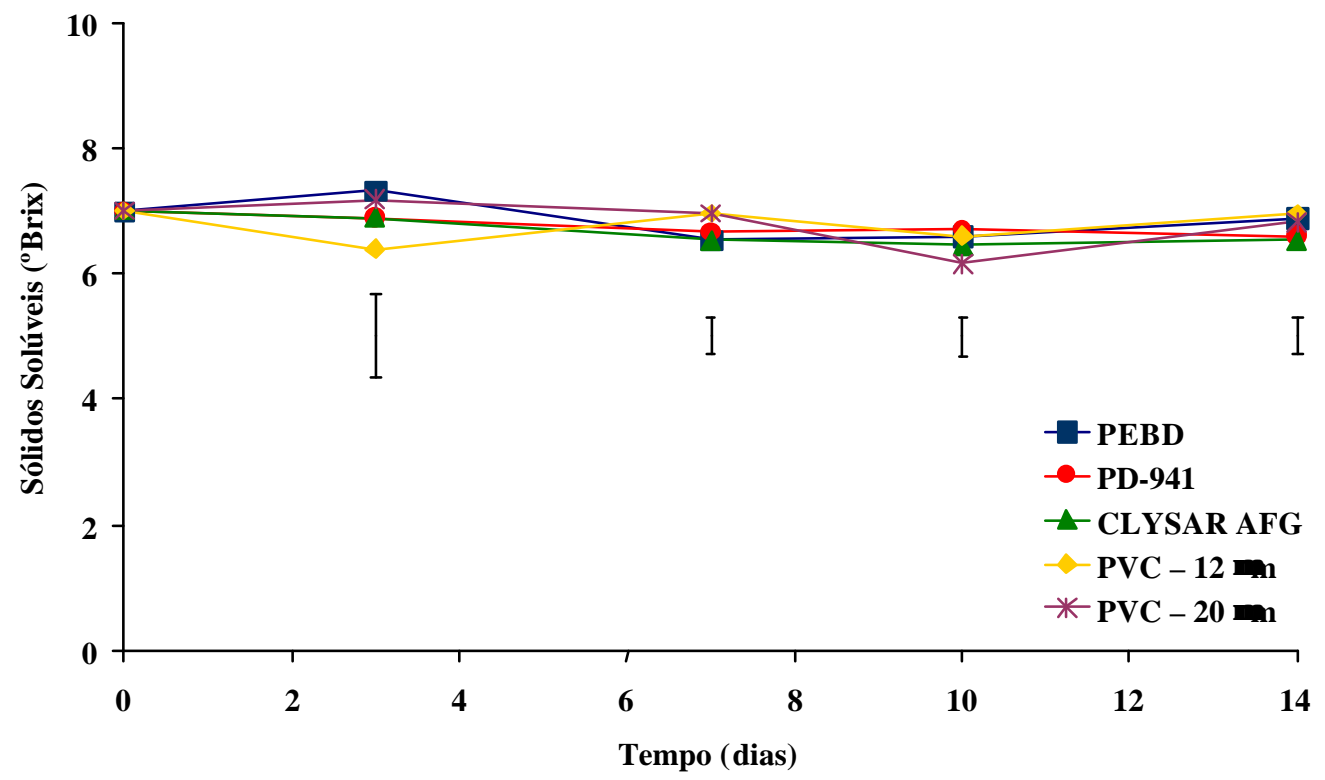

Figura 10 - Sólidos solúveis ( ${ }^{\circ}$ Brix) dos floretes nas diferentes embalagens, mantidos a $5^{\circ} \mathrm{C}$ e $85-95 \%$ de umidade relativa. Barras na vertical indicam a diferença mínima significativa (DMS) $(\mathrm{P} \leq 0,05)$. 
Tabela 4. Sólidos solúveis ( ${ }^{\circ}$ Brix) de floretes nas diferentes embalagens, mantidos a $5^{\circ} \mathrm{C}$ e $85-95 \%$ de umidade relativa.

\begin{tabular}{|c|c|c|c|c|c|c|}
\hline \multirow{2}{*}{ Tratamentos } & \multicolumn{6}{|c|}{ sólidos solúveis $\left({ }^{\circ} \mathrm{Brix}\right)$} \\
\hline & 0 dia & 3 dias & 7 dias & 10 dias & 14 dias & C.V. $(\%)$ \\
\hline PEBD & 7,0 a $\mathrm{AB}$ & 7,3 a $\mathrm{A}$ & 6,5 a B & 6,6 a $\mathrm{AB}$ & 6,9 a $\mathrm{AB}$ & 4,92 \\
\hline PD - 941 & 7,0 a $\mathrm{A}$ & 6,9 a $\mathrm{A}$ & 6,7 a $A$ & 6,7 a $A$ & 6,6 a $A$ & 4,58 \\
\hline CLYSAR AFG & 7,0 a $\mathrm{A}$ & 6,9 a $A$ & 6,5 a $A$ & 6,5 a $A$ & 6,5 a $A$ & 3,65 \\
\hline $\mathrm{PVC}-12 \mu \mathrm{m}$ & 7,0 a $\mathrm{A}$ & 6,4 a $A$ & 7,0 a $A$ & 6,6 a $A$ & 7,0 a $A$ & 8,97 \\
\hline $\mathrm{PVC}-20 \mu \mathrm{m}$ & 7,0 a $A$ & 7,2 a $\mathrm{A}$ & 7,0 a $A$ & 6,2 a B & 6,8 a $\mathrm{AB}$ & 4,60 \\
\hline C.V. $(\%)$ & - & 8,84 & 3,86 & 4,26 & 4,07 & - \\
\hline
\end{tabular}

Médias seguidas da mesma letra minúscula na coluna e maiúscula na linha não diferem entre si, pelo teste de Tukey a $5 \%$ de probabilidade.

O que se observa são pequenas diferenças significativas nos teores de sólidos solúveis dos floretes em PEBD e PVC - $20 \mu \mathrm{m}$ durante os 14 dias de armazenamento a $5^{\circ} \mathrm{C}$. Eles variaram para baixo, mas depois retornaram a um nível maior, não diferindo do inicial.

Carnelossi (2000) também não observou variações de teores de sólidos solúveis em couves minimamente processadas e colocadas em embalagens de polipropileno (PP) e em poliolefínas multicamadas (PD 941, PD 900, B 900) e armazenadas por 7 dias a $5^{\circ} \mathrm{C}$.

Gil et al. (2002) relatam que o teor de sólidos solúveis de tomates minimamente processados variou de 4,7 a 5,4, mas não sofreu efeito significativo das 5 embalagens e/ou das duas temperaturas $\left(0\right.$ e $\left.5^{\circ} \mathrm{C}\right)$ em que foram mantidos por 10 dias.

Durante o armazenamento de couves-flores a $1,5^{\circ} \mathrm{C}$, por 7 dias, o teor de sólidos solúveis também não variou significativamente em 5 das embalagens estudadas por Artés \& Martínez (1999), com exceção das mantidas em PEBD - $15 \mu \mathrm{m}$.

Estes dados confirmam o do presente trabalho e indicam que a modificação da atmosfera, causada pelas diferentes embalagens, associada à baixa temperatura contribui 
para que haja somente pequena perda de substrato, durante os 14 dias de armazenamento dos floretes a $5^{\circ} \mathrm{C}$.

\subsubsection{Vitamina $\mathrm{C}$}

Os teores de vitamina $\mathrm{C}$ dos floretes variaram entre 79 e $100 \mathrm{mg}$ de ácido ascórbico/100g de amostra (Figura 11), estando de acordo com a faixa de valores mínimos e máximos citada por Souci et al. (2000), que é de 57 a 124 mg de ácido ascórbico /100g de couves-flores.

No $3^{\circ}$ dia a $5^{\circ} \mathrm{C}$, os teores de vitamina $\mathrm{C}$ variaram entre as embalagens, e os maiores valores foram os dos floretes em PD - 941 e PEBD. Do $7^{\circ}$ ao $14^{\circ}$ dia, as diferenças variaram muito em função das embalagens, e na PD - 941, os floretes nunca apresentaram níveis de vitamina $\mathrm{C}$ menores que os contidos nas demais (Tabela 5).

Ao longo do tempo, os floretes, em todas as embalagens, apresentaram diminuição de vitamina $\mathrm{C}$, chegando a perda a, aproximadamente, $20 \%$.

Perdas de vitamina C de $13 \%$ são relatadas por Klieber \& Franklin (2000) em couve chinesa minimamente processada e mantida 11 dias a $4^{\circ} \mathrm{C}$. Hussein et al. (2000) também observaram redução estatisticamente significativa no teor de vitamina $\mathrm{C}$ de brócolos e pimentões embalados sob vácuo total, parcial, ou com injeção de gases e mantidos 10 dias a $4^{\circ} \mathrm{C}$. Porém, brócolos embalados perdem menos vitamina $\mathrm{C}$ que os não embalados (Barth et al., 1993 a, b).

De acordo com Lee \& Kader (2000), hortaliças severamente cortadas ou picadas perdem muito vitamina $\mathrm{C}$, que é a mais sensível a perdas durante a fase de pós-colheita. A oxidação pode ocorrer na presença de catalisadores, oxidases ou como resultado do aquecimento, durante o processamento. 


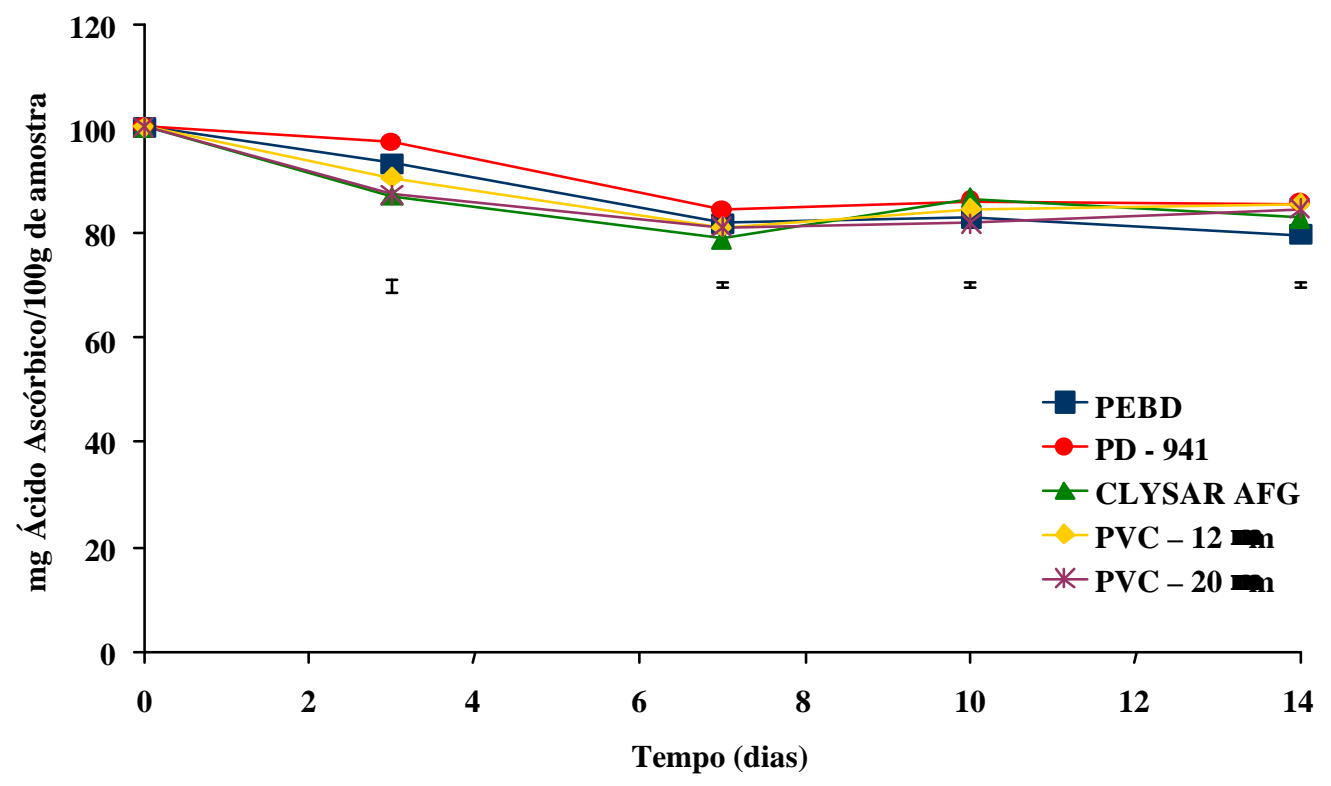

Figura 11 - Vitamina $\mathrm{C}$ dos floretes nas diferentes embalagens, mantidos a $5^{\circ} \mathrm{C}$ e 85 95\% de umidade relativa. Barras na vertical indicam a diferença mínima significativa (DMS) $(\mathrm{P} \leq 0,05)$.

Tabela 5. Vitamina C (mg de ácido ascórbico/100 g de amostra) de floretes em diferentes embalagens, mantidos a $5^{\circ} \mathrm{C}$ e $85-95 \%$ de umidade relativa.

\begin{tabular}{lcccccc}
\hline \multirow{2}{*}{ Tratamentos } & \multicolumn{5}{c}{ vitamina C (mg de ácido ascórbico/100 g de amostra) } \\
& 0 dia & 3 dias & 7 dias & 10 dias & 14 dias & C.V. (\%) \\
\hline PEBD & 100,40 a A & 93,31 ab A & 81,79 ab B & 82,87 ab B & 79,71 b B & 3,79 \\
PD - 941 & 100,40 a A & 97,37 a A & 84,39 a B & 86,16 ab B & 85,71 a B & 3,02 \\
CLYSAR AFG & 100,40 a A & 87,04 b B & 78,99 b C & 86,55 a B & 82,94 ab BC & 2,37 \\
PVC - 12 $\mu \mathrm{m}$ & 100,40 a A & 90,68 b B & 81,15 ab C & 84,66 ab C & 85,61 a C & 2,48 \\
PVC - 20 $\mu \mathrm{m}$ & 100,40 a A & 87,33 b Bb & 81,02 ab C & 81,89 b BC & 84,63 ab CB & 3,31 \\
C.V. $(\%)$ & - & $-3,17$ & 1,48 & 1,97 & 3,08 & - \\
\hline
\end{tabular}

Médias seguidas da mesma letra minúscula na coluna e maiúscula na linha não diferem entre si, pelo teste de Tukey a 5\% de probabilidade. 


\subsubsection{Coloração dos floretes}

A coloração dos floretes permaneceu inalterada $(\mathrm{P} \leq 0,05)$ durante os 14 dias a $5^{\circ} \mathrm{C}$, como se observa pelas Figuras 12 a 14 e Tabelas 6 a 8.

Os resultados mostram que não houve efeito significativo de tratamento e, conseqüentemente, das atmosferas do interior das embalagens, e nem do período em que permaneceram sob refrigeração na coloração dos floretes.

O fato dos valores de "Luminosidade" (Figura 12 e Tabela 6) serem os mesmos para todos os tratamentos e permanecerem iguais ao longo de todo o período de armazenamento significa que não houve escurecimento dos floretes. Por outro lado, o ângulo "Hue" (Figura 14, Tabela 8), também sendo o mesmo, demonstra que não houve mudança de cor, ou seja, de branca para amarela. Nem a intensidade da cor foi alterada pelas atmosferas modificadas e/ou pelo período em que permaneceram a $5^{\circ} \mathrm{C}$, uma vez que o "Croma" (Figura 13, Tabela 7) permaneceu igual para os floretes de todas as embalagens, durante os 14 dias

Resultados semelhantes a estes, como nenhuma mudança significativa de cor ser observada para couves-flores embaladas em 06 sistemas de filmes poliolefínicos, após 7 dias a $1,5^{\circ} \mathrm{C}$ e em um período adicional de 2,5 dias a $20^{\circ} \mathrm{C}$, foram descritos por Artés \& Martínez (1999).

Por outro lado, Berrang et al. (1990) observaram que couves-flores em $\left(18 \% \mathrm{O}_{2}+\right.$ $3 \% \mathrm{CO}_{2}$ e $4^{\circ} \mathrm{C}$ ) apresentaram um menor declínio nos valores de $\mathrm{L}^{*}$ do que as mantidas somente sob $4^{\circ} \mathrm{C}$; ambas tiveram Cromas crescentes, significativamente iguais e "Hue" estáveis e semelhantes estatisticamente. Relatam que uma avaliação subjetiva mostrou que as couves-flores a $4^{\circ} \mathrm{C}$ tornaram-se escurecidas mais cedo do que as mantidas sob refrigeração e atmosfera controlada, associando o escurecimento aos valores menores de $\mathrm{L}^{*}$.

Talvez os baixos níveis de $\mathrm{O}_{2}$ presentes no interior da maioria das embalagens utilizadas neste estudo tenham retardado o escurecimento dos floretes. De acordo com Murr \& Morris (1974), níveis ao redor de $0 \% \quad \mathrm{O}_{2}$ são necessários para impedir a atividade da polifenoloxidase e escurecimento em cogumelos. 


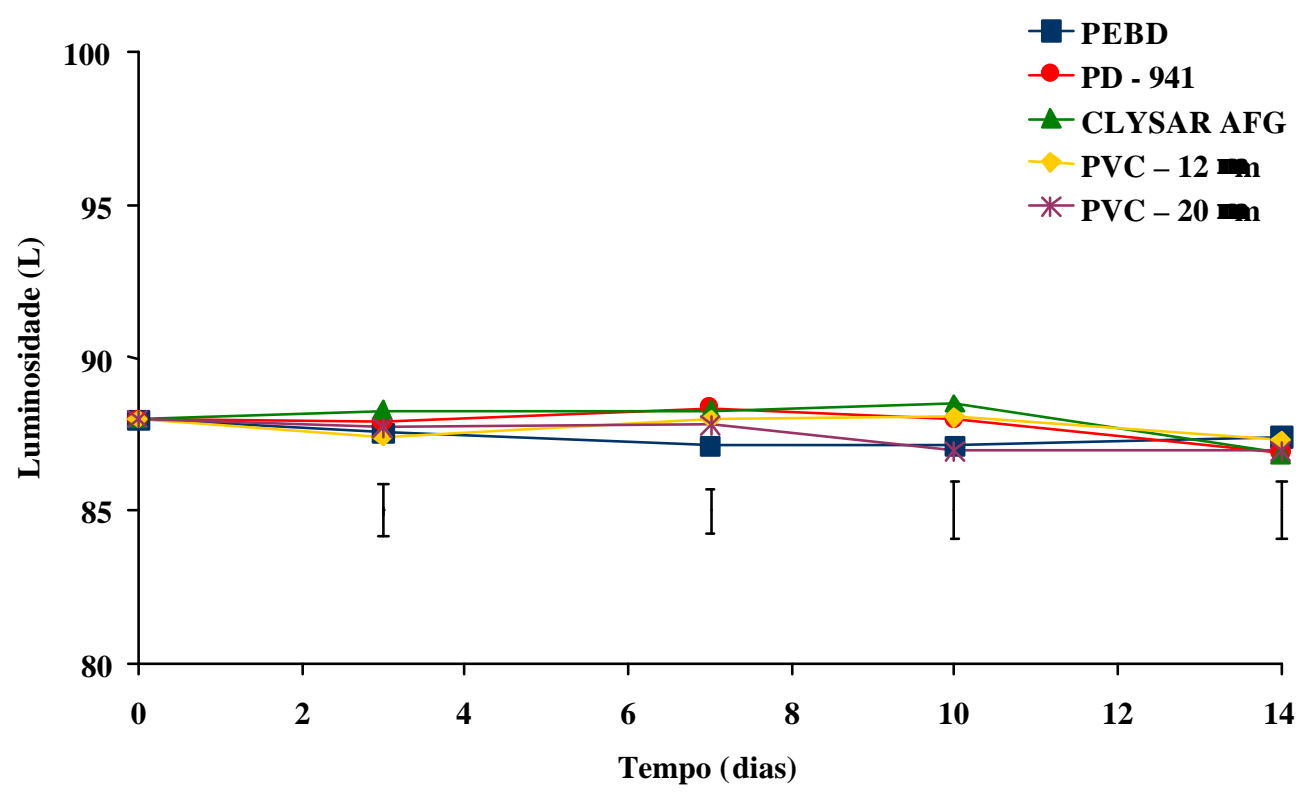

Figura 12 - Valores de luminosidade $\left(\mathrm{L}^{*}\right)$ para os floretes nas diferentes embalagens, mantidos a $5^{\circ} \mathrm{C}$ e $85-95 \%$ de umidade relativa. Barras na vertical indicam a diferença mínima significativa (DMS) $(\mathrm{P} \leq 0,05)$.

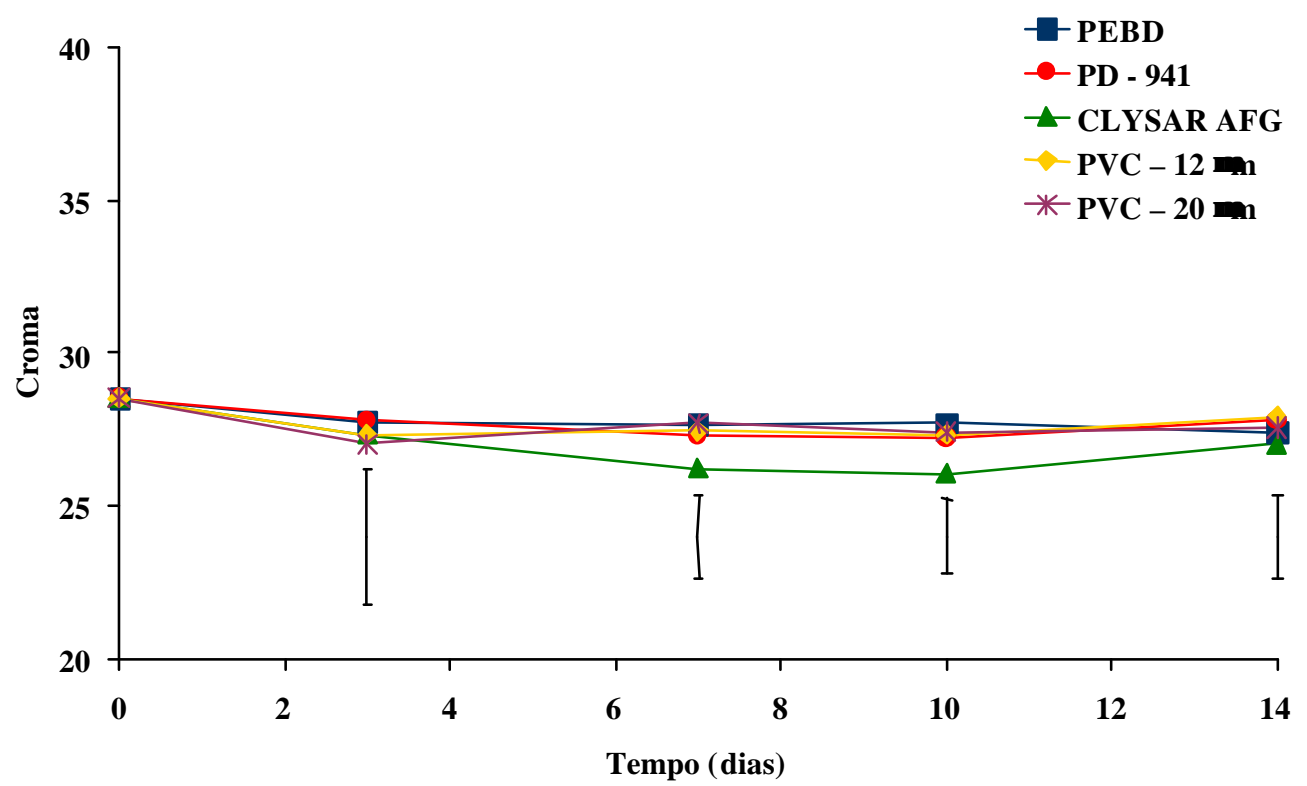

Figura 13 - Valores de croma para os floretes nas diferentes embalagens, mantidos a $5^{\circ} \mathrm{C}$ e $85-95 \%$ de umidade relativa. Barras na vertical indicam a diferença mínima significativa (DMS) $(\mathrm{P} \leq 0,05)$. 


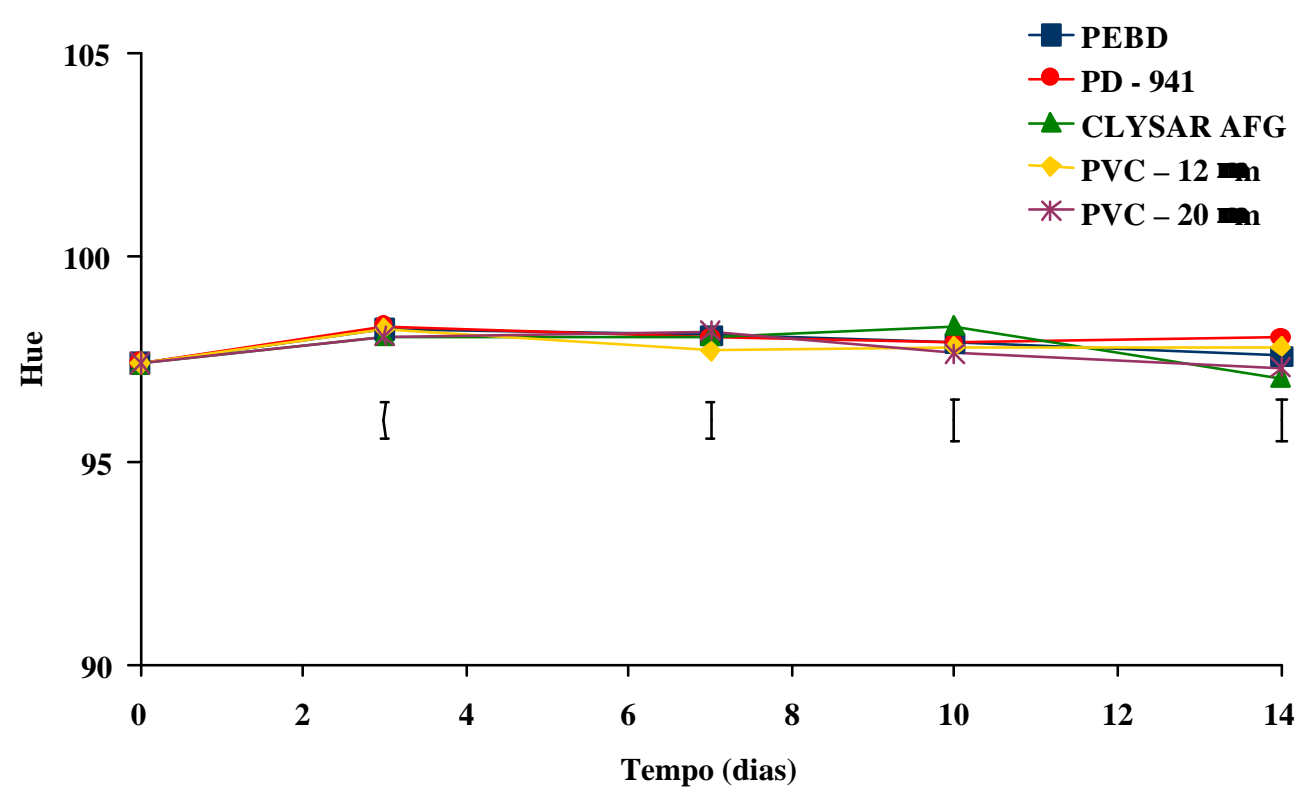

Figura 14 - Valores do ângulo Hue para os floretes nas diferentes embalagens, mantidos a $5^{\circ} \mathrm{C}$ e $85-95 \%$ de umidade relativa. Barras na vertical indicam a diferença mínima significativa (DMS) $(\mathrm{P} \leq 0,05)$.

Tabela 6. Valores de Luminosidade ( $\left.\mathrm{L}^{*}\right)$ para os floretes em diferentes embalagens, mantidos a $5^{\circ} \mathrm{C}$ e $85-95 \%$ de umidade relativa.

\begin{tabular}{lcccccc}
\hline \multirow{2}{*}{ Tratamentos } & \multicolumn{7}{c}{ luminosidade (L*) } \\
& 0 dia & 3 dias & 7 dias & 10 dias & 14 dias & C.V. (\%) \\
\hline PEBD & 88,00 a A & 87,55 a A & 87,14 a A & 87,14 a A & 87,40 a A & 1,07 \\
PD - 941 & 88,00 a A & 87,88 a A & 88,35 a A & 87,99 a A & 86,89 a A & 1,13 \\
CLYSAR AFG & 88,00 a A & 88,25 a A & 88,26 a A & 88,52 a A & 86,88 a A & 1,13 \\
PVC-12 $\mu \mathrm{m}$ & 88,00 a A & 87,43 a A & 88,00 a A & 88,07 a A & 87,31 a A & 1,03 \\
PVC-20 $\mu \mathrm{m}$ & 88,00 a A & 87,70 a A & 87,83 a A & 86,94 a A & 86,94 a A & 1,51 \\
C.V. $(\%)$ & - & 0,88 & 0,76 & 1,00 & 0,97 & - \\
\hline
\end{tabular}

Médias seguidas da mesma letra minúscula na coluna e maiúscula na linha não diferem entre si, pelo teste de Tukey a $5 \%$ de probabilidade. 
Tabela 7. Valores de Croma para os floretes em diferentes embalagens, mantidos a $5^{\circ} \mathrm{C}$ e $85-95 \%$ de umidade relativa.

\begin{tabular}{|c|c|c|c|c|c|c|}
\hline \multirow{2}{*}{ Tratamentos } & \multicolumn{6}{|c|}{ croma } \\
\hline & 0 dia & 3 dias & 7 dias & 10 dias & 14 dias & C.V. (\%) \\
\hline PEBD & $28.53 \mathrm{a} \mathrm{A}$ & 27.76 a $\mathrm{A}$ & $27.65 \mathrm{a} \mathrm{A}$ & $27.72 \mathrm{a} \mathrm{A}$ & $27.40 \mathrm{a} \mathrm{A}$ & 8.2 \\
\hline PD - 941 & $28.53 \mathrm{a} \mathrm{A}$ & 27.80 a $\mathrm{A}$ & $27.29 \mathrm{a} \mathrm{A}$ & $27.24 \mathrm{a} \mathrm{A}$ & 27.82 a A & 7.41 \\
\hline CLYSAR AFG & 28.53 a A & 27.32 a A & 26.24 a A & 26.07 a A & $27.04 \mathrm{a} \mathrm{A}$ & 7.41 \\
\hline $\mathrm{PVC}-12 \mu \mathrm{m}$ & 28.53 a $\mathrm{A}$ & 27.32 a A & $27.46 \mathrm{a} \mathrm{A}$ & 27.32 a A & 27.93 a A & 9.03 \\
\hline $\mathrm{PVC}-20 \mu \mathrm{m}$ & 28.53 a A & $27.04 \mathrm{a} \mathrm{A}$ & 27.70 a $\mathrm{A}$ & 27.44 a A & 27.58 a $\mathrm{A}$ & 7.77 \\
\hline C.V. $(\%)$ & - & 7.41 & 4.64 & 4.11 & 4.53 & - \\
\hline
\end{tabular}

Médias seguidas da mesma letra minúscula na coluna e maiúscula na linha não diferem entre si, pelo teste de Tukey a 5\% de probabilidade.

Tabela 8. Valores do ângulo Hue para os floretes em diferentes embalagens, mantidos a $5^{\circ} \mathrm{C}$ e $85-95 \%$ de umidade relativa.

\begin{tabular}{lcccccc}
\hline \multirow{2}{*}{ Tratamentos } & 0 dia & 3 dias & 7 dias & 10 dias & 14 dias & C.V. (\%) \\
\hline PEBD & 97.4 a A & 98.23 a A & 98.09 a A & 97.88 a A & 97.56 a A & 0.79 \\
PD - 941 & 97.4 a A & 98.30 a A & 98.02 a A & 97.88 a A & 98.02 a A & 0.84 \\
CLYSAR AFG & 97.4 a A & 98.05 a A & 98.05 a A & 98.30 a A & 97.03 a A & 0.8 \\
PVC - 12 $\mu \mathrm{m}$ & 97.4 a A & 98.23 a A & 97.70 a A & 97.78 a A & 97.8 a A & 0.79 \\
PVC - 20 $\mu \mathrm{m}$ & 97.4 a A & 98.05 a A & 98.18 a A & 97.62 a A & 97.31 a A & 0.98 \\
C.V. $(\%)$ & - & 0.48 & 0.49 & 0.59 & 0.55 & - \\
\hline
\end{tabular}

Médias seguidas da mesma letra minúscula na coluna e maiúscula na linha não diferem entre si, pelo teste de Tukey a 5\% de probabilidade. 


\subsubsection{Firmeza}

A firmeza dos floretes se manteve significativamente igual durante todo $\mathrm{o}$ período de 14 dias a $5^{\circ} \mathrm{C}$, para todas as embalagens estudadas. Da mesma forma, as composições gasosas do interior de cada uma das embalagens não tiveram efeito significativo nas firmezas dos floretes, em cada dia de avaliação (Figura 15 e Tabela 9). Estes dados estão de acordo com os obtidos por Berrang et al. (1990) que não notaram diferenças de textura entre couves-flores armazenadas a $4^{\circ} \mathrm{C}$ e as mantidas nesta mesma temperatura, porém sob $18 \% \mathrm{O}_{2}+3 \% \mathrm{CO}_{2}$.

Da mesma forma que as firmezas dos floretes deste experimento oscilaram ao longo do tempo, a firmeza das couves-flores citadas por Berrang et al.(1990) também variou. No presente estudo, o fato dos floretes de uma mesma embalagem provirem de couves-flores diferentes talvez seja o motivo desta oscilação.

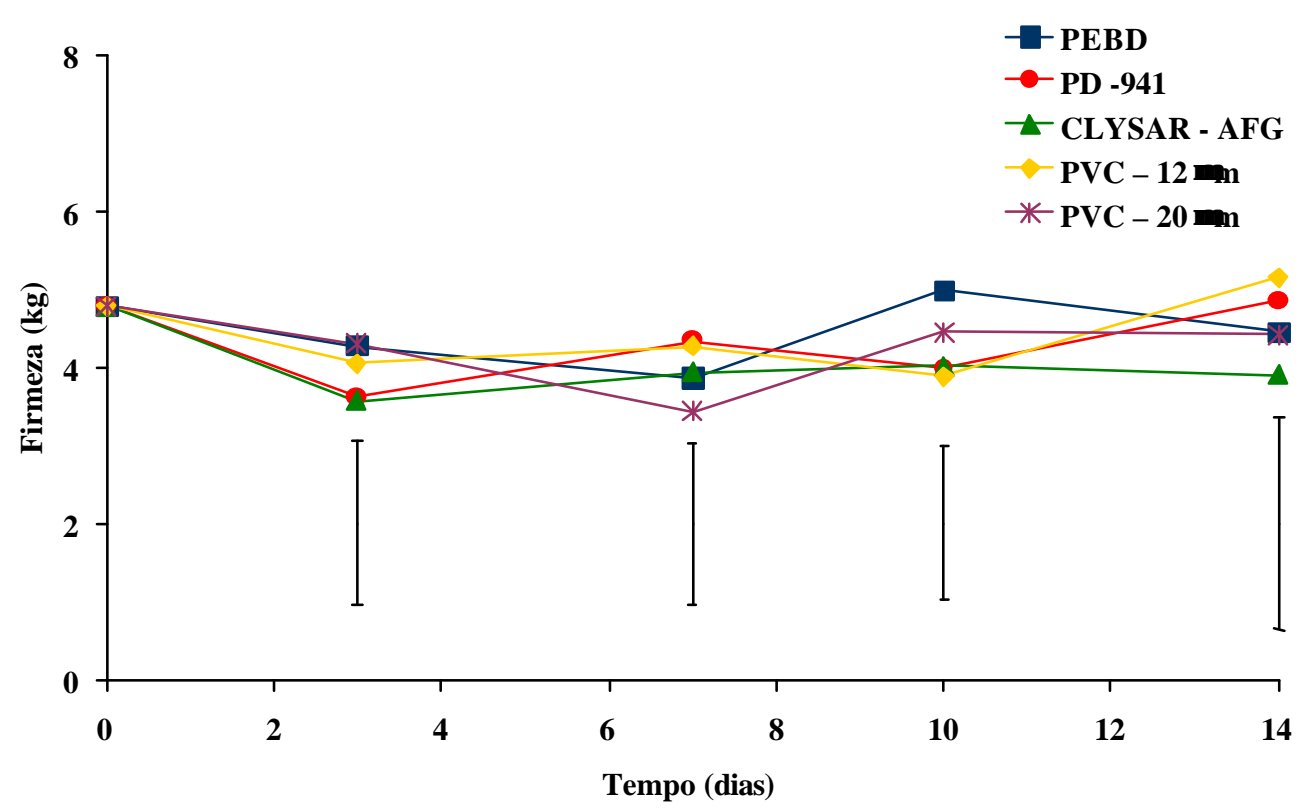

Figura 15 - Valores de firmeza $(\mathrm{kg})$ para os floretes nas diferentes embalagens, mantidos a $5^{\circ} \mathrm{C}$ e $85-95 \%$ de umidade relativa. Barras na vertical indicam a diferença mínima significativa (DMS) $(\mathrm{P} \leq 0,05)$. 
Tabela 9. Valores de firmeza $(\mathrm{kg})$ para os floretes em diferentes embalagens, mantidos a $5^{\circ} \mathrm{C}$ e $85-95 \%$ de umidade relativa.

\begin{tabular}{lcccccc}
\hline \multirow{2}{*}{ Tratamentos } & \multicolumn{5}{c}{ firmeza (kg) } \\
& 0 dia & 3 dias & 7 dias & 10 dias & 14 dias & C.V. (\%) \\
\hline PEBD & 4,79 a A & 4,28 a A & 3,87 a A & 4,98 a A & 4,44 a A & 18,54 \\
PD - 941 & 4,79 a A & 3,63 a A & 4,33 a A & 3,99 a A & 4,85 a A & 15,66 \\
CLYSAR AFG & 4,79 a A & 3,57 a A & 3,93 a A & 4,02 a A & 3,90 a A & 15,9 \\
PVC - $12 \mu \mathrm{m}$ & 4,79 a A & 4,05 a A & 4,27 a A & 3,88 a A & 5,15 a A & 30,46 \\
PVC- $20 \mu \mathrm{m}$ & 4,79 a A & 4,3 a A & 3,45 a A & 4,45 a A & 4,42 a A & 21,37 \\
C.V. $(\%)$ & - & 24,29 & 24,01 & 21,15 & 27,18 & - \\
\hline
\end{tabular}

Médias seguidas da mesma letra minúscula na coluna e maiúscula na linha não diferem entre si, pelo teste de Tukey a 5\% de probabilidade.

\subsubsection{Análises microbiológicas}

Análises realizadas logo após a montagem dos experimentos revelaram que não foi detectada a presença de Salmonella spp. Isto indica que o patógeno não estava presente nas couves-flores ou a sanitização foi eficiente em sua eliminação. Este dado vem ao encontro do preconizado pela Agência Nacional de Vigilância Sanitária (2001) que é a completa ausência desta bactéria em $25 \mathrm{~g}$ do produto.

Com relação aos coliformes totais, observa-se que em todas as embalagens estudadas, com exceção do PVC - $20 \mu \mathrm{m}$, a contagem foi muito baixa $k 10$ Unidades Formadoras de Colônias por grama de floretes), durante todo o período de 14 dias a $5^{\circ} \mathrm{C}$ (Tabela 10). Na embalagem de PVC - $20 \mu \mathrm{m}$ o valor foi alto, $3,1 \times 10^{3} \mathrm{UFC} / \mathrm{g}$ de floretes, a partir do $7^{\circ}$ dia a $5^{\circ} \mathrm{C}$.

Como o método para a determinação de coliformes totais permite a diferenciação dos coliformes fecais (Echerichia coli), estes também foram avaliados, estando sempre ao redor de (< $10 \mathrm{UFC/g}$ floretes), bem abaixo do limite $10^{2} \mathrm{UFC} / \mathrm{g}$ de produto, preconizado pela ANVISA (2001). 
Quanto aos bolores e leveduras, seus níveis mantiveram-se sempre baixos, menores que $10^{2} \mathrm{UFC} / \mathrm{g}$ de floretes (Tabela 11). De acordo com Nguyen-the \& Carlin (1994), as leveduras geralmente não são afetadas por atmosferas modificadas e os bolores tendem a ser inibidos por baixas concentrações de $\mathrm{O}_{2}$ e altas de $\mathrm{CO}_{2}$.

Tabela 10 Contagem de coliformes totais em floretes de diferentes embalagens, mantidos a $5^{\circ} \mathrm{C}$ e $85-95 \%$ de umidade relativa.

\begin{tabular}{lccccc}
\hline \multirow{2}{*}{ Tratamentos } & \multicolumn{4}{c}{ coliformes totais (UFC/g) } & \\
& 0 dia & 3 dias & 7 dias & 10 dias & 14 dias \\
\hline PEBD & $<10$ & $<10$ & $<10$ & $<10$ & $<10$ \\
PD - 941 & $<10$ & $<10$ & $<10$ & $<10$ & $<10$ \\
CLYSAR AFG & $<10$ & $<10$ & $<10$ & $<10$ & $<10$ \\
PVC 12 $\mu \mathrm{m}$ & $<10$ & $<10$ & $<10$ & $<10$ & $<10$ \\
PVC 20 $\mu \mathrm{m}$ & $<10$ & $<10$ & $3,1 \times 10^{3}$ & $3,1 \times 10^{3}$ & $3,1 \times 10^{3}$ \\
\hline
\end{tabular}

* UFC/g = Unidades Formadoras de Colônias por grama de produto.

Tabela 11. Contagem de bolores e leveduras em floretes de diferentes embalagens, mantidos a $5^{\circ} \mathrm{C}$ e $85-95 \%$ de umidade relativa.

\begin{tabular}{|c|c|c|c|c|c|}
\hline \multirow{2}{*}{ Tratamentos } & \multicolumn{5}{|c|}{ bolores e leveduras (UFC/g) } \\
\hline & 0 dia & 3 dias & 7 dias & 10 dias & 14 dias \\
\hline PEBD & $<10^{2}$ & $<10^{2}$ & $<10^{2}$ & $<10^{2}$ & $<10^{2}$ \\
\hline$P D-941$ & $<10^{2}$ & $<10^{2}$ & $<10^{2}$ & $<10^{2}$ & $<10^{2}$ \\
\hline CLYSAR AFG & $<10^{2}$ & $<10^{2}$ & $<10^{2}$ & $<10^{2}$ & $<10^{2}$ \\
\hline PVC $12 \mu \mathrm{m}$ & $<10^{2}$ & $<10^{2}$ & $<10^{2}$ & $<10^{2}$ & $<10^{2}$ \\
\hline PVC $20 \mu \mathrm{m}$ & $<10^{2}$ & $<10^{2}$ & $<10^{2}$ & $<10^{2}$ & $<10^{2}$ \\
\hline
\end{tabular}

* UFC/g = Unidades Formadoras de Colônias por grama de produto. 
Desta forma, as atmosferas no interior das embalagens não contribuíram para o desenvolvimento de microrganismos deteriorantes (bolores, leveduras e coliformes totais) que pudessem comprometer a qualidade de floretes de couves-flores, mesmo a de PVC - $20 \mu \mathrm{m}$, que apresentou 3 ciclos logarítmicos, a partir do $7^{\circ}$ dia a $5^{\circ} \mathrm{C}$.

\subsubsection{Análise sensorial}

No caso de floretes de couves-flores, a preferência dos provadores parece ser para sistemas de embalagens com bandejas, envoltas em filmes de PVC. Na Tabela 12, observa-se que as notas para aparência geral (embalagem + floretes) dos PVC's são ligeiramente superiores que as dos sacos de PEBD e PD - 941, embora não significativamente diferentes $(\mathrm{P} \leq 0,05)$. A melhor aparência geral foi para os floretes em bandejas, envoltos em PVC - $12 \mu \mathrm{m}$, que mantiveram notas elevadas e iguais, durante 10 dias a $5^{\circ} \mathrm{C}$. A pior foi para os floretes contidos em sacos Clysar, que apresentavam excessiva condensação de umidade, impedindo a visualização dos floretes.

De modo geral, até o $10^{\circ}$ dia a $5^{\circ} \mathrm{C}$, as embalagens não provocaram significativo aparecimento de odor estranho em seu interior, no momento em que eram abertas (Tabela 13). Porém, as embalagens de PVC e PEBD mostraram tendência a um leve (nota 2) desenvolvimento de odor estranho a partir do $7^{\circ}$ dia, chegando a diferir significativamente da PD -941, no $14^{\circ}$ dia, que, praticamente, não apresentava nenhum odor desagradável ao ser aberta. Este leve odor estranho parece estar presente em embalagens que apresentaram teores de $\mathrm{CO}_{2}$ próximos ou superiores a 5\%. Conforme descrito anteriormente, odores e sabores estranhos em couves-flores são causados por níveis de CO2 $\geq 5 \%$, porém, após a cocção (Vallespir, 1993). No presente caso, não eram os floretes que estavam com leve odor desagradável, mas sim o ar do interior das embalagens.

A Tabela 14 mostra que nas embalagens de PEBD e PD - 941, os floretes apresentavam-se com qualidade geral de bom (nota 4) a excelente (nota 5), no $10^{\circ}$ dia a 
$5^{\circ} \mathrm{C}$, embora não tivessem diferido significativamente dos floretes das demais embalagens, que obtiveram notas de 3,70.

Tabela 12. Médias das notas atribuídas à aparência geral do conjunto embalagens e floretes mantidos a $5^{\circ} \mathrm{C}$ e $85-95 \%$ de umidade relativa ${ }^{\mathrm{x}}$.

\begin{tabular}{lcccccc}
\hline \multirow{2}{*}{ Tratamentos } & \multicolumn{5}{c}{ aparência geral } \\
& 0 dia & 3 dias & 7 dias & 10 dias & 14 dias & C.V. (\%) \\
\hline PEBD & 5,00 a A & 4,30 ab B & 4,3 ab B & 4,2 ab B & 3,70 a B & 11,7 \\
PD - 941 & 5,00 a A & 4,40 ab B & 4,35 ab B & 3,8 ab C & 3,70 a C & 9,36 \\
CLYSAR AFG & 5,00 a A & 4,20 b B & 4,1 b BC & 3,65 b CD & 3,35 a D & 10,42 \\
PVC-12 $\mu \mathrm{m}$ & 5,00 a A & 4,80 a AB & 4,8 a AB & 4,45 a BC & 4,00 a C & 9,1 \\
PVC-20 $\mu \mathrm{m}$ & 5,00 a A & 4,80 a AB & 4,8 a AB & 4,35 a A & 3,40 a B & 11,85 \\
C.V. $(\%)$ & - & 9,83 & 11,66 & 13,38 & 14,59 & -
\end{tabular}

${ }^{\mathrm{x}}$ Escala de notas: 1 = péssima, $2=$ ruim, $3=$ regular, $4=$ boa, $5=$ excelente.

Médias seguidas da mesma letra minúscula na coluna e maiúscula na linha não diferem entre si, pelo teste de Tukey a 5\% de probabilidade.

Tabela 13. Médias das notas atribuídas ao odor estranho no momento da abertura das embalagens dos floretes mantidos a $5^{\circ} \mathrm{C}$ e $85-95 \%$ de umidade relativa ${ }^{\mathrm{x}}$.

\begin{tabular}{|c|c|c|c|c|c|c|}
\hline \multirow{2}{*}{ Tratamentos } & \multicolumn{6}{|c|}{ odor estranho } \\
\hline & 0 dia & 3 dias & 7 dias & 10 dias & 14 dias & C.V. (\%) \\
\hline PEBD & 1,00 a $A$ & 1,20 a $A$ & 1,20 a $A$ & 1,30 a $A$ & $1,6 \mathrm{ab} A$ & 43,79 \\
\hline PD - 941 & 1,00 a $A$ & 1,00 a $A$ & 1,10 a $\mathrm{A}$ & 1,15 a $A$ & 1,2 a $A$ & 25,68 \\
\hline CLYSAR AFG & 1,00 a $A$ & 1,00 a $\mathrm{A}$ & 1,00 a $\mathrm{A}$ & 1,25 a $A$ & $1,35 \mathrm{ab} A$ & 25,43 \\
\hline $\mathrm{PVC}-12 \mu \mathrm{m}$ & 1,00 a $\mathrm{A}$ & 1,00 a $\mathrm{A}$ & 1,50 a $\mathrm{AB}$ & $1,60 \mathrm{a} A B$ & $1,7 \mathrm{ab} B$ & 36,35 \\
\hline $\mathrm{PVC}-20 \mu \mathrm{m}$ & 1,00 a $\mathrm{A}$ & 1,00 a $\mathrm{A}$ & 1,15 a $\mathrm{A}$ & 1,75 a $\mathrm{B}$ & $2,1 \mathrm{~b} \mathrm{~B}$ & 23,93 \\
\hline C.V. $(\%)$ & - & 18,13 & 35,49 & 33,89 & 38,68 & - \\
\hline
\end{tabular}

${ }^{\mathrm{x}}$ Escala de notas: 1 = ausente, $2=$ leve, $3=$ moderado, $4=$ intenso, $5=$ muito intenso.

Médias seguidas da mesma letra minúscula na coluna e maiúscula na linha não diferem entre si, pelo teste de Tukey a 5\% de probabilidade. 
Tabela 14. Médias das notas atribuídas à qualidade geral dos floretes mantidos a $5^{\circ} \mathrm{C}$ e $85-95 \%$ de umidade relativa ${ }^{x}$.

\begin{tabular}{lrrrrrc}
\hline \multirow{2}{*}{ Tratamentos } & \multicolumn{5}{c}{ qualidade geral dos floretes } \\
& 0 dia & 3 dias & 7 dias & 10 dias & 14 dias & C.V. (\%) \\
\hline PEBD & 5,00 a A & 5,00 a A & 4,80 a A & 4,45 a A & 3,75 a B & 9,69 \\
PD - 941 & 5,00 a A & 5,00 a A & 4,90 a A & 4,40 a A & 3,80 a B & 6,77 \\
CLYSAR AFG & 5,00 a A & 5,00 a A & 4,65 a A & 3,70 a B & 3,50 ab B & 10,58 \\
PVC-12 $\mu \mathrm{m}$ & 5,00 a A & 5,00 a A & 4,65 a A & 3,70 a B & 3,70 a B & 8,76 \\
PVC-20 $\mu \mathrm{m}$ & 5,00 a A & 5,00 a A & 4,90 a A & 3,70 a B & 2,90 b C & 8,06 \\
C.V. $(\%)$ & - & - & 8,51 & 15,14 & 14,15 & -
\end{tabular}

${ }^{\mathrm{x}}$ Escala de notas: 1 = péssima, 2 = ruim, 3 = regular, 4 = boa, 5 = excelente.

Médias seguidas da mesma letra minúscula na coluna e maiúscula na linha não diferem entre si, pelo teste de Tukey a 5\% de probabilidade.

Esta melhor qualidade geral dos floretes em PEBD e PD -941 talvez seja o reflexo das menores notas obtidas pelos floretes destas embalagens em termos de murchamento, deterioração e escurecimento (Tabelas 15 a 17 ), no $10^{\circ}$ dia a $5^{\circ} \mathrm{C}$, embora não necessariamente diferindo significativamente dos demais tratamentos.

A tendência de apresentar leve (nota 2) escurecimento (Tabela 17) pode ser devido a problemas varietais ou induzida pela exposição ao sol (Vallespir, 1993) seguida de baixas temperaturas que podem realçar o defeito de campo, durante o armazenamento (Kays, 1991). Esta tendência não foi detectada objetivamente através do colorímetro, como pode ser observado pelas Figuras 8 a 10 e Tabela 6 a 8 .

As avaliações realizadas após o cozimento dos floretes (Tabelas 18 a 20) sugerem que nenhuma das atmosferas no interior das embalagens causou o aparecimento de odor ou sabor estranho, em qualquer dia de análise. Mesmo nas embalagens de PEBD e PVC - $20 \mu \mathrm{m}$, onde os teores de $\mathrm{CO}_{2}$ superaram $5 \%$ durante todo o período de manutenção a $5^{\circ} \mathrm{C}$, os níveis de sabor e odor estranhos permaneceram bem abaixo do que, segundo a escala de notas adotada, se pode chamar de leve sabor ou odor estranho $($ nota $=2)$. 
Tabela 15. Médias das notas atribuídas ao murchamento dos floretes mantidos a $5^{\circ} \mathrm{C}$ e $85-95 \%$ de umidade relativa ${ }^{x}$.

\begin{tabular}{lcccccc}
\hline \multirow{2}{*}{ Tratamentos } & \multicolumn{5}{c}{ murchamento } \\
& 0 dia & 3 dias & 7 dias & 10 dias & 14 dias & C.V. (\%) \\
\hline PEBD & 1,00 a A & 1,00 a A & 1,00 a A & 1,15 a AB & 1,50 a B & 24,77 \\
PD - 941 & 1,00 a A & 1,00 a A & 1,10 a A & 1,15 a AB & 1,50 a B & 27,27 \\
CLYSAR AFG & 1,00 a A & 1,00 a A & 1,10 a A & 1,30 a AB & 1,60 a B & 32,63 \\
PVC - $12 \mu \mathrm{m}$ & 1,00 a A & 1,00 a A & 1,20 a AB & 1,30 a AB & 1,60 a B & 33,68 \\
PVC- $20 \mu \mathrm{m}$ & 1,00 a A & 1,00 a A & 1,05 a A & 1,20 a AB & 1,60 a B & 31,79 \\
C.V. $(\%)$ & - & - & 26,04 & 31,98 & 40,77 & -
\end{tabular}

${ }^{\mathrm{x}}$ Escala de notas: 1 = ausente, $2=$ leve, $3=$ moderado, 4 = intenso, $5=$ muito intenso.

Médias seguidas da mesma letra minúscula na coluna e maiúscula na linha não diferem entre si, pelo teste de Tukey a 5\% de probabilidade.

Tabela 16. Médias das notas atribuídas à deterioração dos floretes mantidos a $5^{\circ} \mathrm{C}$ e 85 $95 \%$ de umidade relativa ${ }^{\mathrm{x}}$.

\begin{tabular}{lcccccc}
\hline \multirow{2}{*}{ Tratamentos } & \multicolumn{5}{c}{ deterioração } \\
& 0 dia & 3 dias & 7 dias & 10 dias & 14 dias & C.V. (\%) \\
\hline PEBD & 1,00 a A & 1,00 a A & 1,00 a A & 1,15 ab A & 1,90 ab B & 17,09 \\
PD - 941 & 1,00 a A & 1,00 a A & 1,10 a A & 1,10 a A & 1,70 a B & 21,51 \\
CLYSAR AFG & 1,00 a A & 1,00 a A & 1,05 a A & 1,65 bc B & 2,05 ab B & 26,99 \\
PVC - $12 \mu \mathrm{m}$ & 1,00 a A & 1,00 a A & 1,10 a A & 1,5 abc BC & 1,55 a C & 28,74 \\
PVC - $20 \mu \mathrm{m}$ & 1,00 a A & 1,00 a A & 1,00 a A & 1,9 c B & 2,5 b C & 21,13 \\
C.V. $(\%)$ & - & - & 20,2 & 27,68 & 26 & - \\
\hline
\end{tabular}

${ }^{\mathrm{x}}$ Escala de notas: 1 = ausente, $2=$ leve, $3=$ moderado, $4=$ intenso, $5=$ muito intenso.

Médias seguidas da mesma letra minúscula na coluna e maiúscula na linha não diferem entre si, pelo teste de Tukey a 5\% de probabilidade. 
Tabela 17. Médias das notas atribuídas ao escurecimento dos floretes mantidos a $5^{\circ} \mathrm{C}$ e $85-95 \%$ de umidade relativa ${ }^{x}$.

\begin{tabular}{lrrrrrr}
\hline \multirow{2}{*}{ Tratamentos } & \multicolumn{5}{c}{ escurecimento } \\
& dia & 3 dias & 7 dias & 10 dias & 14 dias & C.V.(\%) \\
\hline PEBD & 1,00 a A & 1,00 a A & 1,30 a A & 1,30 a A & 1,90 a B & 23,22 \\
PD - 941 & 1,00 a A & 1,00 a A & 1,20 a AB & 1,50 ab BC & 1,75 a C & 23,75 \\
CLYSAR & 1,00 a A & 1,00 a A & 1,45 a AB & 1,90 bc BC & 1,95 ab C & 24,7 \\
PVC - $12 \mu \mathrm{m}$ & 1,00 a A & 1,00 a A & 1,50 a B & 1,90 bc C & 1,90 ab C & 21,17 \\
PVC - $20 \mu \mathrm{m}$ & 1,00 a A & 1,00 a A & 1,30 a A & 2,00 c B & 2,40 b C & 19,36 \\
C.V. $(\%)$ & - & - & 34,08 & 22,77 & 18,52 & -
\end{tabular}

${ }^{\mathrm{x}}$ Escala de notas: 1 = ausente, 2 = leve, $3=$ moderado, 4 = intenso, $5=$ muito intenso.

Médias seguidas da mesma letra minúscula na coluna e maiúscula na linha não diferem entre si, pelo teste de Tukey a 5\% de probabilidade.

Tabela 18. Médias das notas atribuídas à textura dos floretes mantidos a $5^{\circ} \mathrm{C}$ e $85-95 \%$ de umidade relativa ${ }^{x}$.

\begin{tabular}{lccrccc}
\hline \multirow{2}{*}{ Tratamentos } & \multicolumn{5}{c}{ textura } \\
& 0 dia & 3 dias & 7 dias & 10 dias & 14 dias & C.V. (\%) \\
\hline PEBD & 1,0 a A & 1,3 a AB & 1,3 a AB & 1,6 a BC & 1,9 a C & 30,61 \\
PD - 941 & 1,0 a A & 1,15 a A & 1,95 a B & 1,9 ab B & 2,0 a B & 36,86 \\
CLYSAR AFG & 1,0 a A & 1,65 a AB & 2,05 a B & $2,5 \mathrm{~b} \mathrm{~B}$ & 2,5 a B & 34,58 \\
PVC - $12 \mu \mathrm{m}$ & 1,0 a A & 1,35 a AB & 1,7 a BC & 1,8 a BC & 1,85 a C & 23,21 \\
PVC - $20 \mu \mathrm{m}$ & 1,0 a A & 1,35 a AB & 1,75 a B & 1,8 a B & 2,0 a B & 36,84 \\
C.V. $(\%)$ & - & 32,33 & 42,82 & 26,33 & 32,46 & - \\
\hline
\end{tabular}

${ }^{\mathrm{x}}$ Escala de notas: $1=$ macia, $2=$ pouco macia, $3=$ levemente dura, $4=$ moderadamente dura, $5=$ dura

Médias seguidas da mesma letra minúscula na coluna e maiúscula na linha não diferem entre si, pelo teste de Tukey a 5\% de probabilidade. 
Tabela 19. Médias das notas atribuídas ao sabor estranho dos floretes mantidos a $5^{\circ} \mathrm{C}$ e $85-95 \%$ de umidade relativa ${ }^{x}$.

\begin{tabular}{lcccccc}
\hline \multirow{2}{*}{ Tratamentos } & \multicolumn{5}{c}{ sabor estranho } \\
& 0 dia & 3 dias & 7 dias & 10 dias & 14 dias & C.V. (\%) \\
\hline PEBD & 1,00 a A & 1,00 a A & 1,10 a A & 1,20 a A & 1,30 a A & 28,55 \\
PD - 941 & 1,00 a A & 1,00 a A & 1,00 a A & 1,25 a A & 1,25 a A & 20,32 \\
CLYSAR AFG & 1,00 a A & 1,00 a A & 1,00 a A & 1,00 a A & 1,25 a B & 18,09 \\
PVC - $12 \mu \mathrm{m}$ & 1,00 a A & 1,00 a A & 1,00 a A & 1,15 a A & 1,35 a A & 25,53 \\
PVC - $20 \mu \mathrm{m}$ & 1,00 a A & 1,00 a A & 1,20 a A & 1,20 a A & 1,30 a A & 28,65 \\
C.V. $(\%)$ & - & - & 19,89 & 26,8 & 37,4 & -
\end{tabular}

${ }^{\mathrm{x}}$ Escala de notas: Escala de notas: $1=$ ausente, $2=$ leve, $3=$ moderado, $4=$ intenso, $5=$ muito intenso

Médias seguidas da mesma letra minúscula na coluna e maiúscula na linha não diferem entre si, pelo teste de Tukey a 5\% de probabilidade.

Tabela 20. Médias das notas atribuídas ao odor estranho dos floretes mantidos a $5^{\circ} \mathrm{C}$ e 85 $-95 \%$ de umidade relativa ${ }^{\mathrm{x}}$.

\begin{tabular}{lcccccc}
\hline \multirow{2}{*}{ Tratamentos } & 0 dia & 3 dias & 7 dias & 10 dias & 14 dias & C.V. (\%) \\
\hline PEBD & 1,00 a A & 1,00 a A & 1,00 a A & 1,10 a A & 1,20 a A & 22,24 \\
PD - 941 & 1,00 a A & 1,00 a A & 1,00 a A & 1,10 a A & 1,10 a A & 19,23 \\
CLYSAR AFG & 1,00 a A & 1,00 a A & 1,00 a A & 1,10 a AB & 1,35 a B & 23,39 \\
PVC - $12 \mu \mathrm{m}$ & 1,00 a A & 1,00 a A & 1,00 a A & 1,10 a A & 1,25 a A & 19,82 \\
PVC - $20 \mu \mathrm{m}$ & 1,00 a A & 1,00 a A & 1,00 a A & 1,00 a A & 1,40 a B & 21,38 \\
C.V. $(\%)$ & - & - & - & 24,3 & 34,59 & - \\
\hline
\end{tabular}

${ }^{\mathrm{x}}$ Escala de notas: 1 = ausente, 2 = leve, 3 = moderado, 4 = intenso, $5=$ muito intenso Médias seguidas da mesma letra minúscula na coluna e maiúscula na linha não diferem entre si, pelo teste de Tukey a 5\% de probabilidade. 
Com relação à textura, a PEBD foi a melhor embalagem, pois manteve a textura macia praticamente inalterada por maior período, ou seja, 7 dias. Porém, no $10^{\circ}$ dia, a textura dos floretes desta embalagem só diferiu estatisticamente $(\mathrm{P} \leq 0,05)$ dos da Clysar, que tiveram uma tendência de ter perdido pouco de sua maciez mais cedo, já no $3^{\circ}$ dia, sem contudo atingir o nível de "ligeiramente dura" durante os 14 dias de armazenamento a $5^{\circ} \mathrm{C}$. Neste dia, os floretes de todas as embalagens apresentavam-se com texturas iguais estatisticamente $(\mathrm{P} \leq 0,05)$, porém, sem alterações expressivas que pudessem comprometer a sua qualidade para a comercialização. Floretes ligeiramente duros (nota 3) não foram observados ao longo de todo o período de armazenamento, indicando, portanto, que as embalagens foram eficientes em não deixar que esses floretes entrassem em senescência. Uma das características desta fase é o endurecimento das inflorescências devido à manutenção por períodos prolongados em câmaras frigoríficas (Ryall and Lipton, 1972).

\subsection{Conclusões}

a embalagem poliolefínica PD - 941 manteve níveis de $\mathrm{O}_{2}$ e $\mathrm{CO}_{2}$ mais próximos dos recomendados para couves-flores, quais sejam, $2-3 \% \mathrm{O}_{2}$ e $\mathrm{CO}_{2}<5 \%$;

$>$ embora tenham ocorrido variações nos teores de $\mathrm{pH}$, acidez titulável e sólidos solúveis ( ${ }^{\circ}$ Brix) dos floretes, nas diferentes embalagens, estas oscilações aconteceram numa faixa muito estreita, como $\mathrm{pH}$ entre 6,41 a 6,63; acidez titulável de 0,09 a 0,13 g de ácido málico/100 g de amostra e sólidos solúveis entre 6,2 a 7,3 Brix;

$>$ os teores de vitamina C decresceram, havendo perda de $20 \%$ ao longo de 14 dias a $5^{\circ} \mathrm{C}$, porém, os floretes da $\mathrm{PD}$ - 941 foram os que tiveram as menores perdas;

as atmosferas desenvolvidas nas embalagens tiveram pouca ou nenhuma influência na coloração e firmeza dos floretes, durante 14 dias a $5^{\circ} \mathrm{C}$;

$>$ as embalagens também influenciaram muito pouco o desenvolvimento de microrganismos patogênicos, sendo que na de PVC - $20 \mu \mathrm{m}$ observaram-se níveis mais elevados de coliformes totais, a partir do $7^{\circ}$ dia a $5^{\circ} \mathrm{C}$; 
as análises sensoriais mostram que as embalagens de PD -941 e PEBD sobressaíramse sobre as demais;

$>$ no geral, os floretes de couves-flores mantiveram-se bem durante os 14 dias a $5^{\circ} \mathrm{C}$ em todas as embalagens. 


\section{INFLUÊNCIA DE EMBALAGENS COM FILMES FLEXÍVEIS NA QUALIDADE DE RÚCULA MINIMAMENTE PROCESSADA}

\section{Resumo}

O presente estudo teve por objetivo avaliar a influência de diferentes filmes flexíveis na qualidade de rúculas Folha Larga minimamente processadas e mantidas a $5^{\circ} \mathrm{C}$ e 85 a $95 \%$ de umidade relativa. As embalagens utilizadas foram filmes de polietileno de baixa densidade (PEBD), filmes laminados de polipropileno/polietileno (PP/PE), filmes poliolefínicos coextrusados, tipo PD - 900, filmes poliolefínicos coextrusados, tipo CLYSAR HP e o filme de policloreto de vinila, PVC esticável, tipo OMNI - PR, de $20 \mu \mathrm{m}$, envolvendo bandejas de poliestireno expandido. As embalagens de PEBD e PP/PE foram as melhores, em termos de manutenção da qualidade das rúculas minimamente processadas, pois mantiveram níveis mais elevados de sólidos solúveis, vitamina $\mathrm{C}$ e firmeza, além de terem obtido melhores notas para a presença de odor estranho, qualidade geral das folhas, deterioração, manutenção da coloração verde e murchamento. Porém, no $10^{\circ}$ dia, as folhas de todas as embalagens haviam atingido níveis bastante elevados $\left(10^{5}\right)$ de coliformes totais, limitando seu consumo. Analisandose a influência das embalagens em todos os atributos de qualidade estudados pode-se concluir que as atmosferas desenvolvidas no interior das embalagens de PEBD e PP/PE, ao redor de 5 a $7 \%$ de $\mathrm{O}_{2}$ e 10 a $15 \%$ de $\mathrm{CO}_{2}$, são benéficas para a manutenção de rúculas minimamente processadas na forma de folhas soltas e mantidas a $5^{\circ} \mathrm{C}$.

Palavras-chave: Eruca sativa L., embalagens, atmosfera modificada, vida-de-prateleira, atributos de qualidade. 


\section{Summary}

The objective of this study was to evaluate the influence of different packaging materials on the quality of fresh-cut Folha Larga salad rocket held at $5{ }^{\circ} \mathrm{C}$ and $85-95 \%$ RH for a 14-day period. The packages were made from low-density polyethylene film (PEBD), laminated polypropylene/polyethylene film (PP/PE), co-extruded polyolefins, such as PD - 900 and Clysar HP, and stretchable $20 \mu \mathrm{m}$ polyvinil chloride (PVC) overwrapping expanded polystyrene trays. PEBD and PP/PE were shown to be the best packaging materials to maintain high quality of the fresh-cut salad rocket for 10 days, with respect to soluble solids and vitamin $\mathrm{C}$ contents and firmness retention. Furthermore, these packaging materials achieved the best scores for presence of offodors, overall quality, decay, green color retention and shriveling. As far as microorganisms were concerned, no Salmonella spp was detected and fecal coliform counts were below $10 \mathrm{CFU} / \mathrm{g}$. However, total coliforms reached $5 \mathrm{log} \mathrm{CFU} / \mathrm{g}$ on the $10^{\text {th }}$ day at $5^{\circ} \mathrm{C}$ for all packaging materials, and the fresh-cut salad rocket became inappropriate for consumption as from this day. Considering the various factors studied, it would appear that the atmosphere developed inside the packages made from PEBD and PP/PE, about 5-7\% $\mathrm{O}_{2}$ and $10-15 \% \mathrm{CO}_{2}$, was beneficial for the maintenance of minimally processed salad rockets held at $5^{\circ} \mathrm{C}$

Key-words: Eruca sativa L, packaging, modified atmosphere, shelf-life, quality attributes 


\subsection{Introdução}

A rúcula, muito apreciada na forma de saladas, em São Paulo e no Sul do Brasil, vem sendo oferecida aos consumidores dos grandes centros urbanos destes Estados, na forma de folhas soltas, lavadas, higienizadas e embaladas, prontas para o consumo.

O que se observa nas gôndolas dos supermercados são rúculas minimamente processadas, com prazo de validade de 4 a 6 dias, já que são altamente perecíveis, murchando e amarelecendo rapidamente.

Mesmo quando ainda não sofreu o processamento mínimo, a rúcula tem pequena durabilidade após a colheita, sendo que em condições ambientes, a hortaliça pode ser mantida no máximo por um dia, desde que colocada em local bem fresco, com a parte inferior em uma vasilha com água. Em geladeira, a rúcula pode ser mantida por até 4 dias, desde que embalada em saco plástico (Tavares et al., 2000a). Acondicionamento em saco plástico também é recomendado por Trani \& Passos (1998) se se quiser armazenar rúcula a 4 a $10^{\circ} \mathrm{C}$ e umidade relativa de 90 a $95 \%$.

Armazenamentos em baixas temperaturas e altos níveis de umidade relativa são necessários para se retardar perdas de água, de peso e de clorofila e ajudar na manutenção de atributos de qualidade de hortaliças folhosas (Roura et al., 2000a).

A perda de água (transpiração) das hortaliças pode ser uma das principais causas de sua deterioração, pois além de resultar na perda de peso, deprecia a aparência geral, devido ao murchamento e enrugamento, faz com que haja perda de textura, tornando-as mais moles, flácidas e com menor crocância e compromete sua qualidade nutricional, pois contribui para a perda de vitaminas (Kader, 1986). Em órgãos inteiros, a água dos espaços intercelulares não está diretamente exposta ao meio ambiente. Porém, em tecidos que sofreram danos físicos ou mecânicos, por operações de descascamento e/ou corte, as taxas de evaporação de água aumentam drasticamente. Assim, a diferença de perda de água entre tecidos vegetais inteiros e danificados pode variar de 5 a 10 vezes para órgãos com superfícies levemente suberizadas como cenouras; de 10 a 100 vezes, para órgãos com cutículas nas superfíícies, como hortaliças folhosas, de frutos imaturos, 
etc; e, até 500 vezes, para tecidos muito suberizados como os de batatinhas (Brecht, 1995).

Por outro lado, a retenção da coloração verde é um dos mais importantes indicadores de qualidade para as verduras, por ter grande impacto no consumidor, no momento da compra (Roura et al., 2000b). Naturalmente, durante o processo de senescência dos tecidos vegetais já ocorre a degradação da clorofila, principal pigmento das hortaliças de folhas. Porém, o processamento torna-o ainda mais susceptível à degradação por induzir os tecidos vegetais à mudanças estruturais e químicas. Reações enzimáticas e a liberação de ácidos orgânicos de tecidos danificados são parcialmente responsáveis pela mais rápida degradação de clorofila (Heaton et al., 1996).

A recomendação da utilização de sacos plásticos, associados à baixas temperaturas e altas umidades relativas, é uma forma de se contornar, dentro de certos limites, estas alterações indesejáveis e se prolongar a vida de prateleira de rúculas minimamente processadas. De qualquer forma, depois de sofrer leve processo, as rúculas têm que ser necessariamente embaladas e o material plástico tem sido a melhor opção.

Os filmes poliolefínicos em associação com os produtos hortifrutícolas alteram as composições gasosas no interior das embalagens. Níveis elevados de $\mathrm{CO}_{2}$ e baixos de $\mathrm{O}_{2}$ resultam em reduzida perda de clorofila e reduzido acúmulo de outros pigmentos como carotenóides em brócolos (Barth et al., 1993a, Barth et al., 1993b; Barth \& Zhuang, 1996; Zhuang et al., 1994); menores alterações de textura (Weichmann, 1986) e menores decréscimos de ácido ascórbico (Lee \& Kader, 2000) em frutas e hortaliças.

Outros benefícios, além da modificação da atmosfera no interior de embalagens de filmes poliolefínicos são: manutenção de altas taxas de umidade relativa e, conseqüentemente, redução da perda de água do produto; melhoria da sanitização, reduzindo a contaminação durante as etapas de transporte, distribuição, exposição nas gôndolas dos supermercados; redução da disseminação de doenças de um produto para o outro; facilidade da identificação de marcas e colocação de informações importantes aos consumidores (Kader \& Watkins, 2000).

Porém, atmosferas modificadas, altos níveis de umidade no interior das embalagens, associados a várias das práticas de preparo e qualidade inicial das hortaliças 
podem alterar a microbiota, favorecendo o desenvolvimento de microrganismos patogênicos ao homem e deterioradores de tecidos vegetais (Brackett, 1987; Guerzoni et al., 1996 e Francis et al., 1999).

A inexistência de dados sobre a influência que a modificação da atmosfera no interior de embalagens de filmes flexíveis tem na qualidade de rúculas minimamente processadas levou ao presente estudo.

\subsection{Material e métodos}

Rúculas Folha-Larga foram colhidas, nas primeiras horas da manhã, de plantação comercial, no município de Sumaré (SP).

Após a colheita, a hortaliça foi imediatamente transportada para o Centro de Pesquisa e Desenvolvimento de Hortícolas (FRUTHOTEC), do Instituto de Tecnologia de Alimentos - ITAL, Campinas (SP), onde foi mantida por proximadamente 03 (três) horas, em câmaras frigoríficas a $5 \pm 1^{\circ} \mathrm{C}$ e $90 \pm 5 \%$ de umidade relativa.

No início da tarde do dia da colheita, as rúculas foram transferidas para uma área a $16^{\circ} \mathrm{C}$, limpa e higienizada, para serem submetidas às operações de processamento mínimo.

Com o auxílio de facas novas, muito bem afiadas, cortaram-se as raízes das rúculas, tomando-se o cuidado para que as folhas permanecessem unidas por suas bases.

Foram, então, inicialmente lavadas em $200 \mathrm{~L}$ de água a $5^{\circ} \mathrm{C}$, contida em uma banheira de aço inoxidável, com capacidade para 500 L. Nesta primeira lavagem, retiraram-se sujeiras maiores, como partículas de solo presentes nas folhas das rúculas, etc.

Em seguida foram novamente lavadas em água a $5^{\circ} \mathrm{C}$, para a certificação de que toda a sujeira mais grossa havia sido eliminada.

Com a finalidade de facilitar a remoção de possíveis insetos e complementar a lavagem, as hortaliças foram imersas, por 30 segundos, em uma solução a $1 \%$ de SUMA-D29 ${ }^{\circledR}$. Este produto é um sabão líquido (Divoplus v3-2) apropriado a frutas e hortaliças, tendo como princípio ativo, sabão potássico de ácidos graxos de soja/coco e é 
fabricado pela Diversey Lever - Indústrias Gessy Lever Ltda. Esta solução foi preparada com água previamente resfriada a $5^{\circ} \mathrm{C}$, como toda a água utilizada durante as outras etapas dos processamentos mínimos.

O excesso de sabão líquido das rúculas foi retirado pela sua imersão em água a $5^{\circ} \mathrm{C}$.

Somente, então, é que foram imersas em solução a $0,66 \%$ de SUMAVEG $^{\circledR}(3 \%$ de cloro ativo), por 5 minutos, com o intuito de sanitização. Este produto tem como princípio ativo o Dicloro-S-Triazinatriona Sódica Diidratada e é fabricado pela Diversey Lever - Indústrias Gessy Lever Ltda.

As rúculas foram centrifugadas por 45 segundos, em equipamento "AngeloPo", de fabricação italiana, com 750 giros/minuto.

Após a centrifugação, as rúculas tiveram sua base cortada para que as folhas ficassem soltas.

Após, as folhas foram selecionadas e padronizadas quanto ao tamanho, ausência de defeitos, amarelecimento e murchamento.

Procedeu-se à pesagem, de forma a se obter lotes de aproximadamente $150 \mathrm{~g}$ de folhas, nos seguintes sistemas de embalagens:

a) sacos plásticos de filme de polietileno de baixa densidade (PEBD), sendo que a termossoldagem foi feita em uma seladora por impulso elétrico (Haramura);

b) sacos plásticos de filme laminado de polipropileno/polietileno (PP/PE), fabricado pela UNIPAC, sendo que a termossoldagem foi feita em uma seladora por impulso elétrico (Haramura);

c) sacos plásticos de filme poliolefínico coextrusado, tipo PD - 900, fabricado pela CRYOVAC, sendo que a termossoldagem foi feita em uma seladora por impulso elétrico (Haramura);

d) sacos plásticos de filme poliolefínico coextrusado, tipo CLYSAR HP, fabricado pela DuPont, sendo que a termossoldagem foi feita em uma seladora por impulso elétrico (Haramura);

e) filme de policloreto de vinila - PVC esticável, tipo OMNI-PR, fabricado pela Goodyear, envolvendo bandejas de poliestireno expandido (270 x150 x 35 mm), da 
marca Meiwa, modelo M-56, sendo que a ermossoldagem do filme sob a bandeja foi feita em seladora, dotada de chapa aquecida (Ipeal).

As características dos sistemas de embalagens estão apresentadas na Tabela 21, sendo que todos os sacos possuíam $350 \mathrm{~mm}$ x $230 \mathrm{~mm}$.

Tabela 21. Características dos sistemas de embalagens utilizados para folhas de rúculas.

\begin{tabular}{lcccc}
\hline \multicolumn{1}{c}{ Embalagem } & $\begin{array}{c}\text { Espessura } \\
(\boldsymbol{\mu} \mathbf{m})\end{array}$ & \multicolumn{2}{c}{ Taxa de Permeabilidade } & $\begin{array}{c}\text { Área de Permeação } \\
\mathbf{O}_{\mathbf{2}}\end{array}$ \\
\hline PEBD & 75 & 1.287 & 6.385 & 690 \\
PP/PE & 70 & 2.084 & 5.545 & 690 \\
PD - 900 & 40 & 4.119 & 22.360 & 690 \\
Clysar HP & 38 & 2.713 & 10.853 & 690 \\
PVC & 20 & 5.140 & 53.187 & 840 \\
\hline
\end{tabular}

Determinada sob Condições Normais de Temperatura e Pressão (CNTP) e expressa em $\mathrm{cm}^{3} / \mathrm{m}^{2} /$ dia.

Após a embalagem, as folhas foram colocadas em câmara frigorífica a $5 \pm 1^{\circ} \mathrm{C}$ e $85-95 \%$ de umidade relativa.

Aos $0,3,7,10$ e 14 dias de permanência das folhas de rúculas sob refrigeração, 04 embalagens de cada um dos 05 tratamentos foram submetidas às seguintes análises:

a) composição gasosa no interior das embalagens: leitura direta de percentagem de $\mathrm{O}_{2}$ e $\mathrm{CO}_{2}$ através de analisador PBI Dansensor, modelo Combi Check 9800-1;

b) pH: determinado no suco extraído das folhas através de centrífuga Walita, com leitura direta em pHmetro digital Mettler Toledo, modelo 320, de acordo com metodologia descrita em Carvalho et al. (1990);

c) acidez titulável: determinada potenciometricamente no suco previamente preparado, seguindo metodologia descrita em Carvalho et al.(1990) e expressando os resultados em g de ácido málico/100g de amostra;

d) sólidos solúveis: determinados no suco das folhas, com leitura direta em refratômetro manual ATAGO e resultados expressos em ${ }^{\circ}$ Brix (Carvalho et al., 1990); 
e) vitamina C: determinada por titulometria, de acordo com metodologia descrita em Carvalho et al. (1990) e os resultados expressos em mg de ácido ascórbico por 100g de amostra;

f) coloração: leitura direta de L (Luminosidade), C (Croma) e H (Hue) realizada em 04 pontos de cada uma das 04 folhas que foram retiradas de cada uma das 04 repetições de embalagens, por tratamento, perfazendo um total de 64 leituras por tratamento em cada dia de análise;

c) firmeza: determinada por leitura direta da força máxima de cisalhamento em 05 gramas de folhas, através de texturômetro TAXT-2i (célula de $25 \mathrm{~kg}$ ) equipado com ponteira Kramer de 5 lâminas, sendo as velocidades de pré-teste, teste e pós-teste, respectivamente, de $5,1,5$ e $5 \mathrm{~mm} / \mathrm{s}$, a distância de penetração de $50 \mathrm{~mm}$ e os resultados em kg representam a média de 12 determinações por tratamento/dia;

g) análises microbiológicas: $25 \mathrm{~g}$ de folhas foram homogeneizadas em "Stomacher" por 1 minuto em $225 \mathrm{~mL}$ de tampão fosfato $\mathrm{pH} \mathrm{7,0,} \mathrm{preparando-se} \mathrm{diluições} \mathrm{decimais}$ sucessivas para a realização dos seguintes exames: i) contagem total de coliformes totais e de coliformes fecais Escherichia coli), em PETRIFILM 6410, da 3M; ii) contagem total de bolores e leveduras, através do plaqueamento em superfície , utilizando-se o Ágar Dicloram Rosa de Bengala Cloranfenicol (DRBC); iii) Salmonella spp determinada somente no primeiro dia, através do método rápido TECRA UNIQUE; todos realizados conforme metodologias descritas em Silva et al.(2001).

h) análise sensorial: uma equipe de 10 provadores não-treinados avaliou os seguintes atributos de qualidade do produto: aparência geral (conjunto embalagem + folhas), odor estranho (ao se abrir as embalagens), qualidade geral das folhas, murchamento, deterioração e cor (Figura 16).

O delineamento utilizado foi o inteiramente casualizado com quatro repetições para cada tratamento. Os dados, com exceção dos microbiológicos e sensoriais, foram submetidos à análise de variância e as médias comparadas pelo teste Tukey a $5 \%$ de probabilidade, utilizando-se o programa estatístico SAS (SAS Institute, Inc., 1996). 


\section{FICHA DE AVALIAÇÃO}

Experimento: Influência de embalagens com filmes flexíveis na qualidade de rúculas minimamente processadas

Provador:

Data:

Instruções: Por favor, dê notas de acordo com as escalas descritas abaixo para cada um dos atributos constantes no seguinte quadro:

\begin{tabular}{|l|c|c|c|c|c|}
\hline \multirow{2}{*}{ ATRIBUTO } & \multicolumn{5}{c|}{ TRATAMENTOS } \\
\cline { 2 - 6 } & $\mathbf{1}$ & $\mathbf{2}$ & $\mathbf{3}$ & $\mathbf{4}$ & $\mathbf{5}$ \\
\hline Aparência geral (embalagem + folhas) & & & & & \\
\hline Odor estranho (ao abrir embalagem) & & & & & \\
\hline Qualidade geral das folhas & & & & & \\
\hline Murchamento & & & & & \\
\hline Deterioração & & & & & \\
\hline Cor & & & & & \\
\hline
\end{tabular}

ESCALAS DE NOTAS

\section{Aparência geral}

1. Péssima

2. Ruim

3. Regular

4. Boa

5. Excelente

Murchamento

1 Ausente

2. Leve

3. Moderado

4. Intenso

5. Muito intenso
Odor estranho

1 Ausente

2. Leve

3. Moderado

4. Intenso

5. Muito intenso

Deterioração

1 Ausente

2. Leve

3. Moderada

4. Intensa

5. Muito intensa
Qualidade geral

1. Péssima

2. Ruim

3. Regular

4. Boa

5. Excelente

Cor

1 Verde

2. Verde-Clara

3. Verde-Amarelada

4. Amarela-Esverdeada

5. Amarela

\section{Obs.: Quando for o caso, notas intermediárias podem ser utilizadas}

Figura 16 - Ficha de avaliação e escalas de notas utilizadas para análise sensorial das folhas de rúculas em diferentes embalagens. 


\section{3 Resultados e discussão}

\subsubsection{Composição gasosa no interior das embalagens}

Os comportamentos dos teores de oxigênio e de gás carbônico no interior das diferentes embalagens de rúculas minimamente processadas (folhas soltas) e mantidas a $5^{\circ} \mathrm{C}$ por 14 dias estão apresentados nas Figuras 17 e 18.

Os teores de oxigênio no interior das embalagens, como esperado, decrescem com o tempo, atingindo níveis tão baixos quanto $0,29 \%$ e 1,80\%, para os sacos de PEBD e PP/PE, respectivamente, e tão elevados quanto $15,32 \%$ para as de PVC, no $14^{\circ}$ dia de armazenamento a $5^{\circ} \mathrm{C}$. Teores intermediários, ao redor de $6 \%$, foram observados para a PD - 900 e Clysar (Figura 17). Estas concentrações de $\mathrm{O}_{2}$ nas embalagens estão relacionadas às suas taxas de permeabilidade, sendo que o PEBD apresenta a menor taxa e o PVC, a maior.

No $3^{\circ}$ dia de manutenção das folhas de rúculas a $5^{\circ} \mathrm{C}$, já se observou diferenciação nos teores de $\mathrm{O}_{2}$ no interior das embalagens. Deste dia em diante, o filme de PVC mantém níveis de $\mathrm{O}_{2}$ superiores aos das demais embalagens, parecendo ser o único que atinge um equilíbrio em termos deste gás, ao redor de $15-16 \%$. Este equilíbrio é atingido a partir do $3^{\circ}$ dia, sendo que a concentração de $\mathrm{O}_{2}$ mantém-se, portanto, quase que constante, durante os demais dias, até o $14^{\circ} \mathrm{C}$.

Vários são os exemplos de embalagens nas quais não se atinge uma atmosfera de equilíbrio em seu interior, durante o período de armazenamento estudado: tomates minimamente processados em filme de $80 \mu \mathrm{m}$, armazenados a $0^{\circ}$ e a $5^{\circ} \mathrm{C}$, é um deles, onde as concentrações de $\mathrm{O}_{2}$ e $\mathrm{CO}_{2}$ variaram durante os 10 dias de armazenamento, sem que o equilíbrio fosse atingido (Gil et al., 2002); couve chinesa em sacos de polipropileno (PP) a $5^{\circ} \mathrm{C}$ (Kim \& Klieber, 1999) e acelgas embaladas em filmes (sem especificação) a $6^{\circ} \mathrm{C}$ (Gil et al., 1998) são outros exemplos de que nem sempre a interação hortaliça $x$ embalagem favorece $\mathrm{o}$ estabelecimento de uma atmosfera de equilibrio no interior das embalagens. 


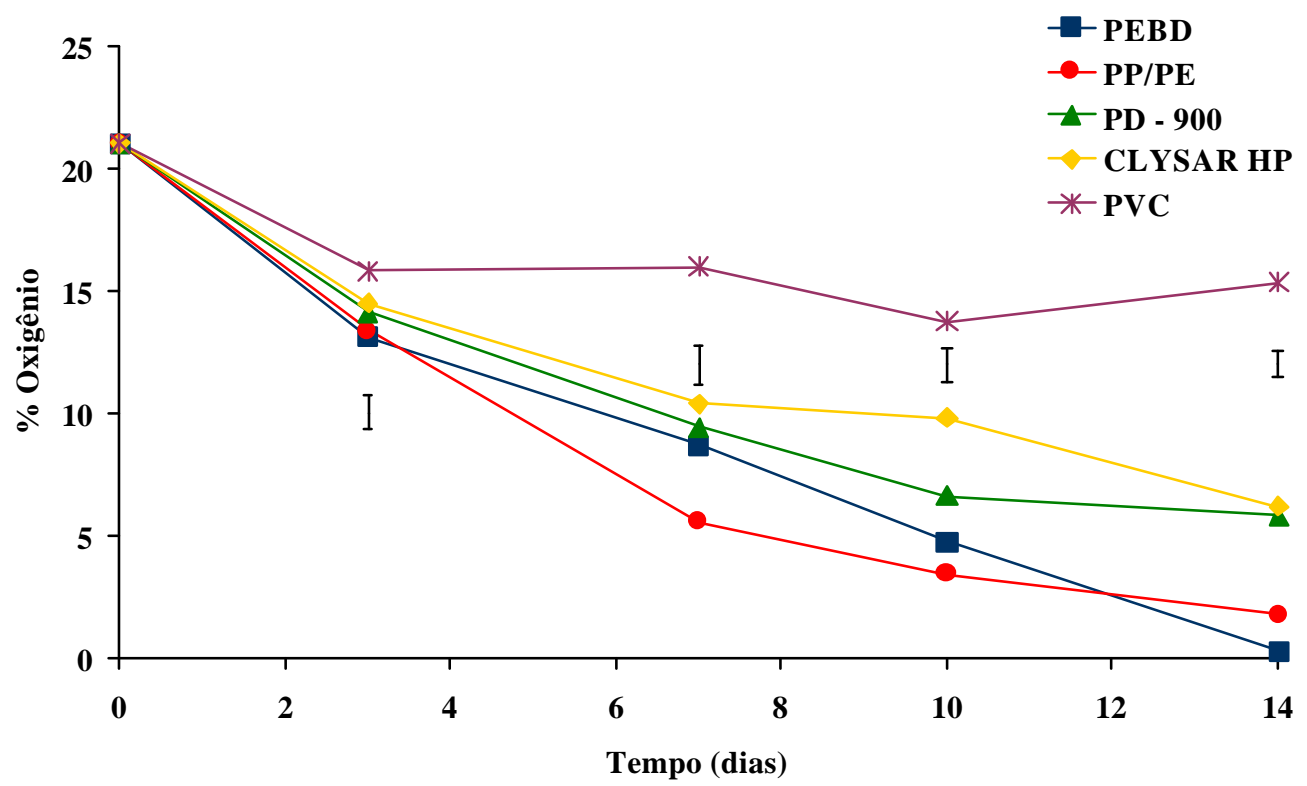

Figura 17 - Evolução do teor de oxigênio no interior das embalagens de folhas de rúculas mantidas a $5^{\circ} \mathrm{C}$ e $85-95 \%$ de umidade relativa. Barras na vertical indicam a diferença mínima significativa $(\mathrm{DMS})(\mathrm{P} \leq 0,05)$.

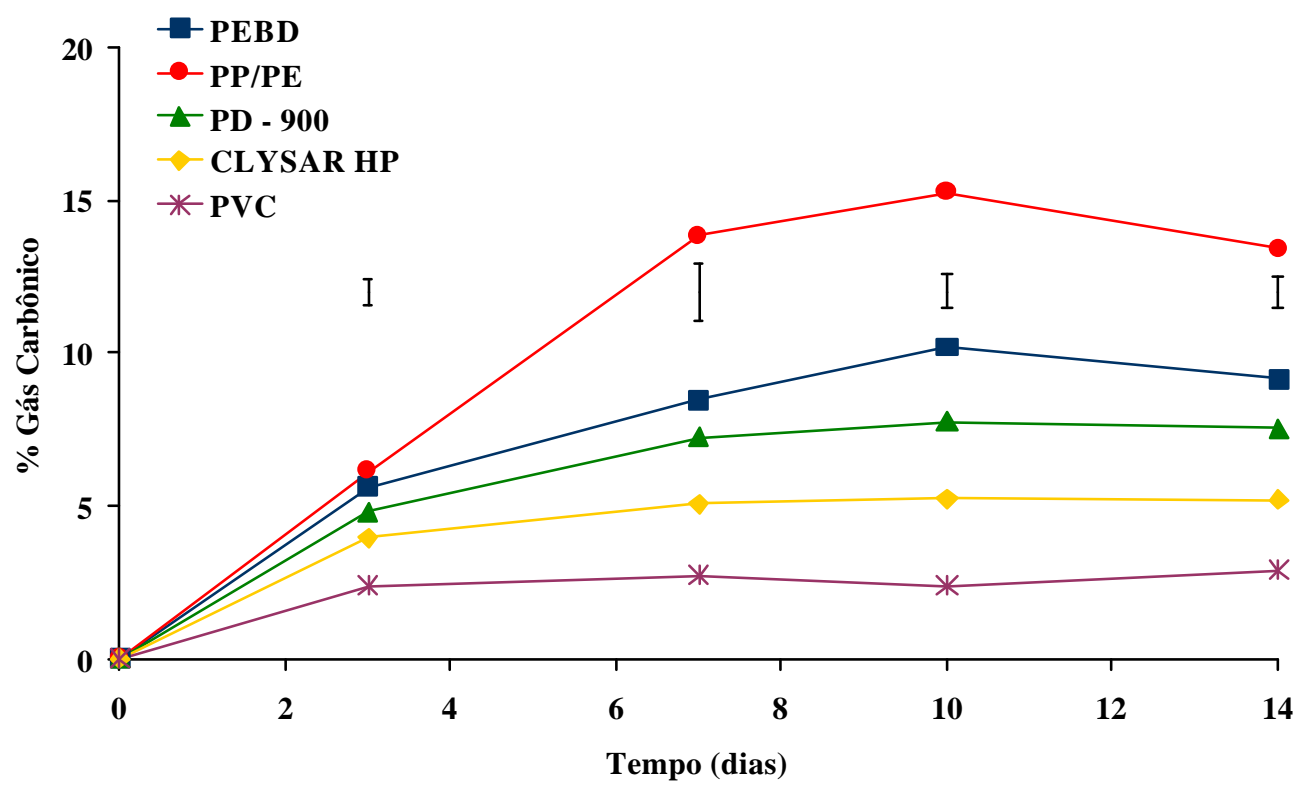

Figura 18 - Evolução do teor de gás carbônico no interior das embalagens de folhas de rúculas mantidas a $5^{\circ} \mathrm{C}$ e $85-95 \%$ de umidade relativa. Barras na vertical indicam a diferença mínima significativa (DMS) $(\mathrm{P} \leq 0,05)$. 
Com relação ao gás carbônico, diferenças significativas $(\mathrm{P} \leq 0,05)$ foram observadas em todos os dias de análise, quanto ao acúmulo de $\mathrm{CO}_{2}$, nos diferentes materiais de embalagem, em função de suas permeabilidades a este gás. Porém, o equilíbrio parece ter sido atingido em todos eles (Figura 18).

Níveis de $13 \%$ a $15 \% \mathrm{CO}_{2}$ foram atingidos a partir do $7^{\circ}$ dia, nas embalagens de PP/PE que possuíam a menor taxa de permeabilidade ao $\mathrm{CO}_{2}$ e de $2,40 \%$ a $2,93 \%$, a partir do $3^{\circ}$ dia, nas embalagens de PVC, que possuem a maior taxa de permeabilidade ao $\mathrm{CO}_{2}$ (Figura 18 e Tabela 21).

Nas demais embalagens, o $\mathrm{CO}_{2}$ entrou em equilíbrio a partir do $7^{\circ}$ dia, sendo entre $8,48 \%$ a 10,20\% para os sacos de PEBD; 7,23\% a 7,78\% para os de PD - 900 e $5,10 \%$ a 5,28\% para os da Clysar HP.

Atmosferas em equilíbrio no interior de embalagens de produtos minimamente processados são altamente desejáveis e relatadas em vários estudos. Com floretes de brócolos, Barth et al. (1993b) observaram que em 96 horas a $10^{\circ} \mathrm{C}$, o $\mathrm{CO}_{2}$ e $\mathrm{O}_{2}$ equilibraram-se em $8 \%$ e $10 \%$, respectivamente. Com couves minimamente processadas, o equilíbrio de gases no interior de embalagens $\mathrm{PD}-941$, a $5^{\circ}$ e $10^{\circ} \mathrm{C}$, foi observado logo na primeira determinação, aos três dias de armazenamento, podendo ter ocorrido antes deste período, conforme afirma Carnelossi (2000). Em seu estudo, os níveis de $\mathrm{O}_{2}$ e $\mathrm{CO}_{2}$ foram, respectivamente, de $2 \%$ e $1,2 \%$, quando as couves estiveram a $10^{\circ} \mathrm{C}$, e $1 \%$ $\mathrm{O}_{2}$ e $2 \% \mathrm{CO}_{2}$, quando armazenadas a $5^{\circ} \mathrm{C}$.

\subsection{2 pH e acidez titulável}

Em cada dia de análise, o $\mathrm{pH}$ e acidez titulável das folhas de rúculas foram significativamente os mesmos em quase todas as embalagens, exceção ao $\mathrm{pH}$ das folhas em PEBD, no $3^{\circ}$ dia, e em PVC, no $14^{\circ}$ dia (Figuras 19 e 20, Tabelas 22 e 23).

As rúculas minimamente processadas apresentaram, ao longo do período de armazenamento, aumento de $\mathrm{pH}$ e correspondente diminuição de acidez titulável, em cada uma das embalagens utilizadas. 


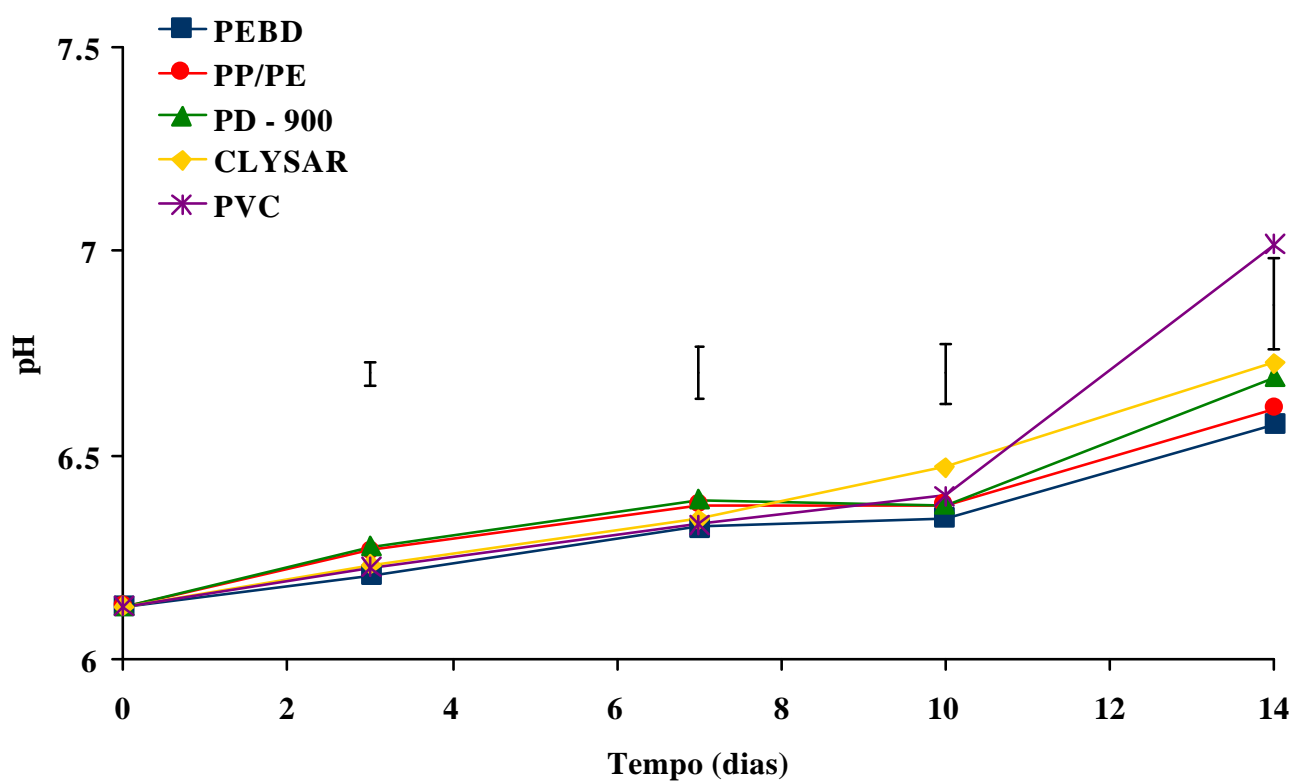

Figura 19 - $\mathrm{pH}$ das folhas de rúculas nas diferentes embalagens, mantidas a $5^{\circ} \mathrm{C}$ e 85 95\% de umidade relativa. Barras na vertical indicam a diferença mínima significativa (DMS) $(\mathrm{P} \leq 0,05)$.

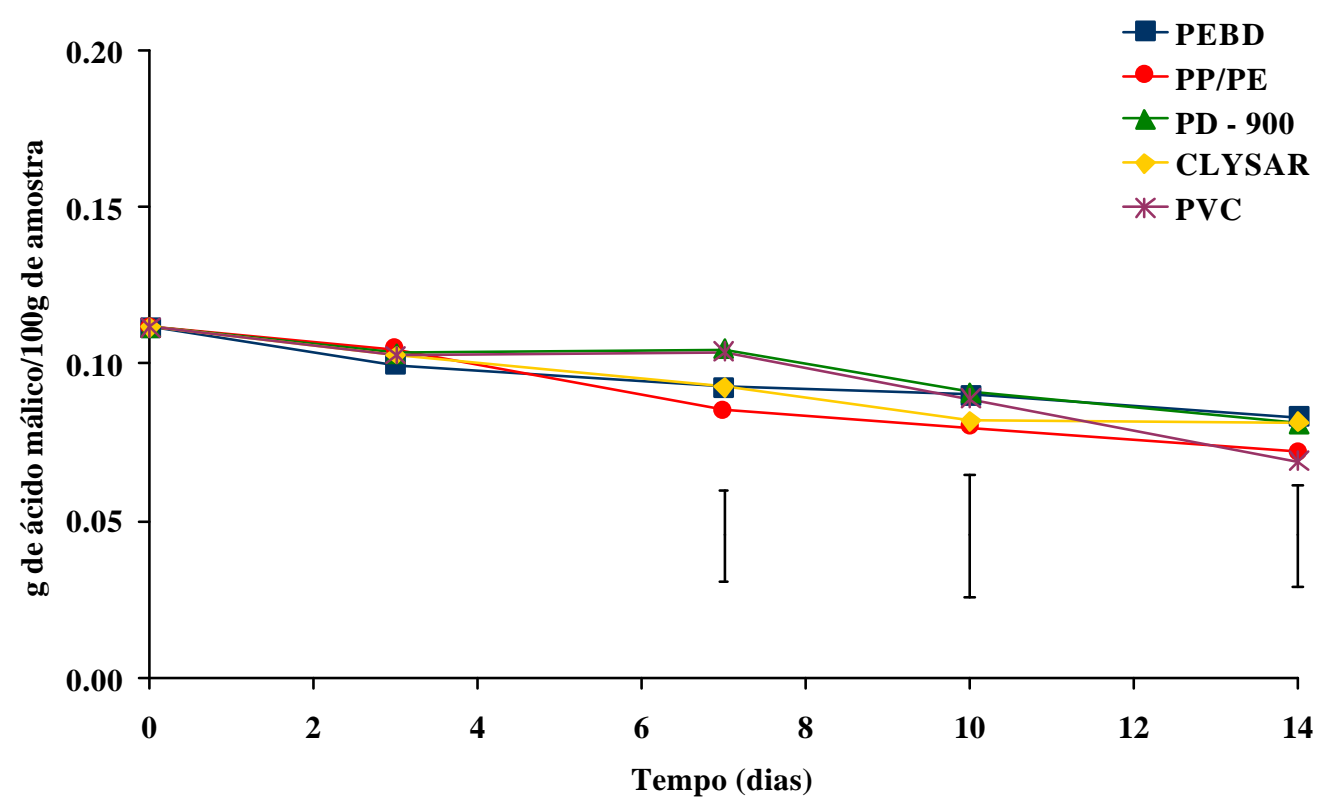

Figura 20 - Acidez titulável (g de ácido málico/100 g de amostra) das folhas de rúculas nas diferentes embalagens, mantidas a $5^{\circ} \mathrm{C}$ e $85-95 \%$ de umidade relativa. Barras na vertical indicam a diferença mínima significativa (DMS) $(\mathrm{P} \leq 0,05)$. 
Tabela 22. $\mathrm{pH}$ de folhas de rúculas em diferentes embalagens, mantidas a $5^{\circ} \mathrm{C}$ e $85-95 \%$ de umidade relativa.

\begin{tabular}{|c|c|c|c|c|c|c|}
\hline \multirow[t]{2}{*}{ Tratamentos } & \multicolumn{6}{|c|}{$\mathrm{pH}$} \\
\hline & 0 dia & 3 dias & 7 dias & 10 dias & 14 dias & $\begin{array}{l}\text { C.V. } \\
(\%)\end{array}$ \\
\hline PEBD & 6,13 a $C$ & $6,21 \mathrm{~b} \mathrm{BC}$ & 6,32 a B & 6,35 a B & $6,58 \mathrm{~b} \mathrm{~A}$ & 1,05 \\
\hline $\mathrm{PP} / \mathrm{PE}$ & 6,13 a C & 6,27 a BC & 6,38 a B & 6,38 a B & 6,62 b A & 1,30 \\
\hline$P D-900$ & 6,13 a $C$ & 6,28 a B & 6,39 a B & 6,38 a $B$ & $6,69 \mathrm{~b} \mathrm{~A}$ & 1,04 \\
\hline CLYSAR HP & 6,13 a C & $6,23 \mathrm{ab} C$ & 6,34 a BC & 6,47 a B & $6,73 \mathrm{~b} \mathrm{~A}$ & 1,34 \\
\hline PVC & 6,13 a C & 6,23 ab BC & 6,33 a BC & 6,40 a B & 7,02 a $\mathrm{A}$ & 1,85 \\
\hline $\mathrm{CV}(\%)$ & - & 0,41 & 0,93 & 1,08 & 1,52 & - \\
\hline
\end{tabular}

Médias seguidas da mesma letra minúscula na coluna e maiúscula na linha não diferem entre si, pelo teste de Tukey a 5\% de probabilidade.

Tabela 23. Acidez titulável ( $\mathrm{g}$ de ácido málico/100 g de folhas de rúculas) de folhas de rúculas em diferentes embalagens, mantidas a $5^{\circ} \mathrm{C}$ e $85-95 \%$ de umidade relativa.

\begin{tabular}{lcccccc}
\hline Tratamentos & \multicolumn{7}{c}{ g de ácido málico/100g de folhas de rúculas } \\
& 0 dia & 3 dias & 7 dias & 10 dias & 14 dias & C.V. \\
& & & & & & $(\%)$ \\
\hline PEBD & 0,11 a A & 0,10 a AB & 0,09 ab B & 0,09 a B & 0,08 a B & 8,72 \\
PP/PE & 0,11 a A & 0,10 a AB & 0,09 ab B & 0,08 a C & 0,07 a C & 9,57 \\
PD - 900 & 0,11 a A & 0,10 a AB & 0,10 a AB & 0,09 a BC & 0,08 a C & 7,14 \\
CLYSAR HP & 0,11 a A & 0,10 a AB & 0,09 ab BC & 0,08 a C & 0,08 a C & 7,93 \\
PVC & 0,11 a A & 0,10 a AB & 0,10 a AB & 0,09 a B & 0,07 a C & 9,51 \\
CV (\%) & - & - & 6,86 & 10,40 & 9,65 & - \\
\hline
\end{tabular}

Médias seguidas da mesma letra minúscula na coluna e maiúscula na linha não diferem entre si, pelo teste de Tukey a 5\% de probabilidade. 
Aumentos de $\mathrm{pH}$ têm sido relatados para vários produtos inteiros ou que foram submetidos ao processamento mínimo.

Morangos sob diferentes concentrações de $\mathrm{CO}_{2}$ apresentaram aumento de $\mathrm{pH}$ e menor acidez, durante um período de 10 dias de armazenamento; sendo que os maiores aumentos corresponderam aos que estavam sob maiores concentrações de $\mathrm{CO}_{2}$ (Holcroft \& Kader, 1999).

Com hortaliças minimamente processadas, foi observado que independentemente da embalagem utilizada, o pH de couves tendeu a se elevar após 5 dias de armazenamento a $5^{\circ} \mathrm{C}$, sendo que os maiores valores foram daquelas em PD - 900, menos permeável ao $\mathrm{CO}_{2}$ (Carnelossi, 2000).

Em acelgas, houve grandes decréscimos da acidez titulável durante os 3 primeiros dias de armazenamento a $4^{\circ} \mathrm{C}$, sendo que os maiores decréscimos estiveram associados aos maiores danos nos tecidos provocados pelo processamento mínimo (Roura et al., 2000b). Estes pesquisadores associam este decréscimo da acidez a uma respiração maior do tecido vegetal logo após o processamento mínimo.

Por outro lado, Izumi et al.(1996) atribuem o aumento de $\mathrm{pH}$ em produtos minimamente processados ao aumento da carga microbiana.

Para rúculas minimamente processadas, os maiores acúmulos de $\mathrm{CO}_{2}$ foram para as embalagens de PP/PE e PEBD (Figura 18) que não apresentaram valores de $\mathrm{pH}$ maiores que as demais (Figura 19). Aumento de respiração em função da área danificada pela ação do corte, com o conseqüiente consumo de ácidos orgânicos e decréscimos na acidez titulável também parece não ser o caso de rúculas que sofreram poucos danos mecânicos quando da separação das folhas. Porém, a microbiota das folhas de rúcula aumentou a partir do $3^{\circ}$ dia a $5^{\circ} \mathrm{C}$ (Tabela 30), parecendo ser a responsável pelo aumento do pH e diminuição da acidez titulável, como afirma Izumi et al.(1996). 


\subsubsection{Sólidos solúveis}

Os valores de sólidos solúveis das rúculas minimamente processadas permaneceram iguais para todas as embalagens até o $10^{\circ}$ dia e avaliação. No $14^{\circ}$ dia houve diferenças significativas entre eles, sendo que as folhas nas embalagens de PEBD e PP/PE apresentaram os maiores valores, porém não diferentes aos da rúcula em PD 900 e Clysar HP. Estas tiveram seus sólidos solúveis iguais aos das rúculas em PVC, que apresentaram os menores valores de ${ }^{\circ}$ Brix, ou seja, 3,1. (Figura 21 e Tabela 24).

Ao longo do período de armazenamento a $5^{\circ} \mathrm{C}$, na mesma embalagem, não houve alteração nos valores de ${ }^{\circ}$ Brix para as rúculas mantidas em PEBD, PP/PE, HD - 900 e Clysar HP. No $14^{\circ}$ dia, observou-se que, para as folhas em PVC, ocorreu um leve decréscimo, porém significativo.

A embalagem de PVC, por ser muito permeável (Tabela 21), talvez não tenha permitido a modificação da atmosfera suficiente para reduzir a respiração das folhas, como ocorreu com as outras embalagens, havendo, portanto, um maior consumo de substratos e, conseqüentemente, decréscimo nos níveis de sólidos solúveis.

Em acelgas minimamente processadas, observou-se uma diminuição nos teores de sólidos solúveis durante o armazenamento a $4^{\circ} \mathrm{C}$, sendo que os maiores decréscimos ocorreram nos três primeiros dias e em acelgas que sofreram, propositadamente, maiores danos durante o processamento. Roura et al. (2000b) atribuíram este decréscimo a um aumento na atividade respiratória, principalmente, em acelgas com maiores danos mecânicos.

Nas demais embalagens, o teor de sólidos solúveis não sofreu grandes variações porque a baixa temperatura, associada às atmosferas desenvolvidas no seu interior talvez tenha contribuído para um menor consumo de substratos, devido a uma respiração menor das folhas. 


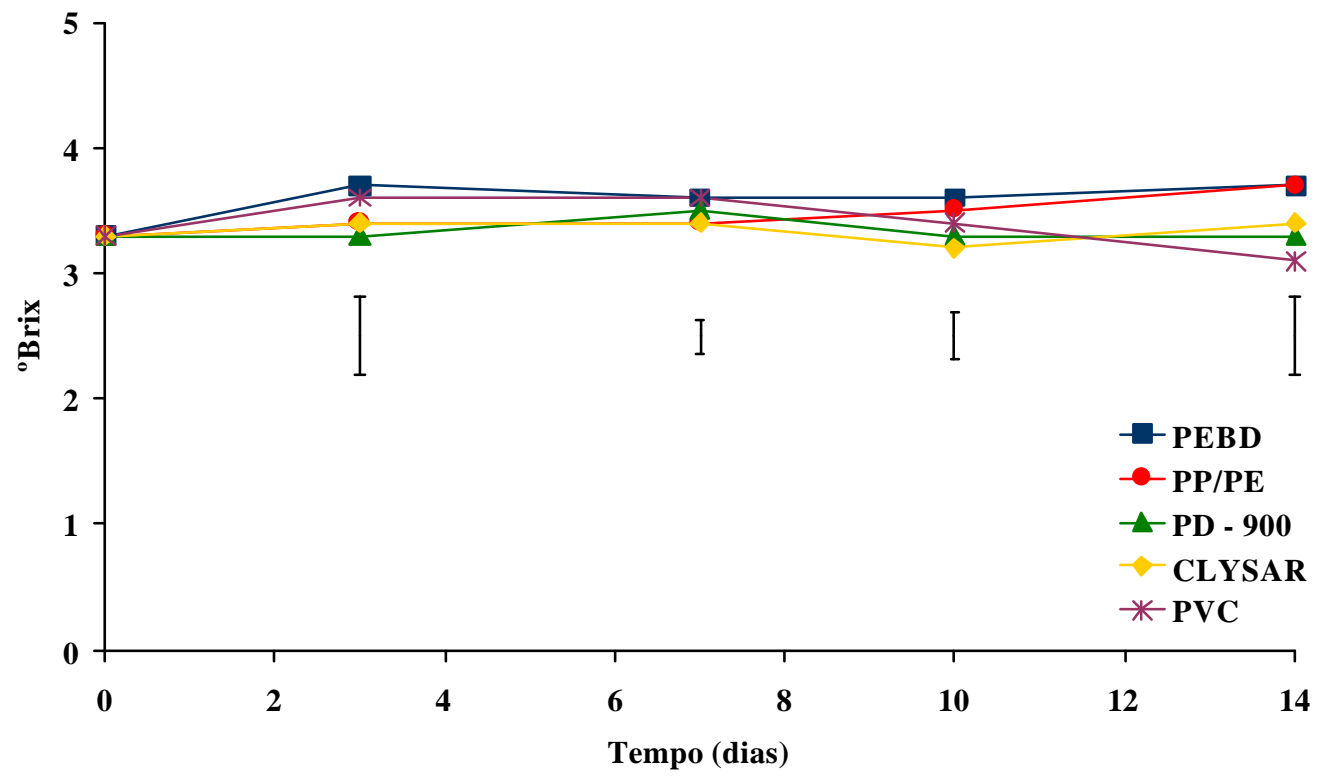

Figura 21 - Sólidos solúveis ( ${ }^{\circ}$ Brix) das folhas de rúculas nas diferentes embalagens, mantidas a $5^{\circ} \mathrm{C}$ e $85-95 \%$ de umidade relativa. Barras na vertical indicam a diferença mínima significativa (DMS) $(\mathrm{P} \leq 0,05)$.

Tabela 24. Sólidos solúveis ( ${ }^{\circ}$ Brix) das folhas de rúculas nas diferentes embalagens, mantidas a $5^{\circ} \mathrm{C}$ e $85-95 \%$ de umidade relativa.

\begin{tabular}{lcccccc}
\hline \multicolumn{1}{c}{ Tratamentos } & \multicolumn{5}{c}{ Sólidos Solúveis ( ${ }^{\circ}$ Brix) } \\
& 0 dia & 3 dias & 7 dias & 10 dias & 14 dias & C,V, (\%) \\
\hline PEBD & 3,3 a A & 3,7 a A & 3,6 a A & 3,6 a A & 3,7 a A & 6,48 \\
PP/PE & 3,3 a A & 3,4 a A & 3,4 a A & 3,5 a A & 3,7 a A & 8,82 \\
PD - 900 & 3,3 a A & 3,3 a A & 3,5 a A & 3,3 a A & 3,3 ab A & 3,97 \\
CLYSAR & 3,3 a A & 3,4 a A & 3,4 a A & 3,2 a A & 3,4 ab A & 4,69 \\
PVC & 3,3 a A & 3,6 a A & 3,6 a A & 3,4 a AB & 3,1 b B & 4,95 \\
CV $(\%)$ & - & 8,33 & 3,48 & 5,11 & 8,27 & - \\
\hline
\end{tabular}

Médias seguidas da mesma letra minúscula na coluna e maiúscula na linha não diferem entre si, pelo teste de Tukey a 5\% de probabilidade. 


\subsubsection{Vitamina C}

Nos diferentes dias de análises, com exceção do $7^{\circ}$ dia, observa-se através da Figura 22 e Tabela 25 que não houve diferenças significativas entre os níveis de vitamina $\mathrm{C}$ das folhas de rúculas nas diferentes embalagens.

Porém, perdas significativas de vitamina $\mathrm{C}$ ocorreram nos três primeiros dias de armazenamento das folhas de rúculas em todas as embalagens a $5^{\circ} \mathrm{C}$.

Do $3^{\circ}$ dia em diante, até o $14^{\circ}$ dia, os níveis de vitamina $\mathrm{C}$ das folhas de rúculas em PEBD, PP/PE e PD -900 tiveram leves decréscimos, não-significativos. Para a Clysar HP e PVC, os decréscimos foram significativos, sendo que, nesta última, a perda total ficou ao redor de $45 \%$.

Kader (1986) relata que o armazenamento em atmosferas controladas resulta em melhor retenção de ácido ascórbico em frutas e hortaliças do que quando mantidas em ar ambiente.

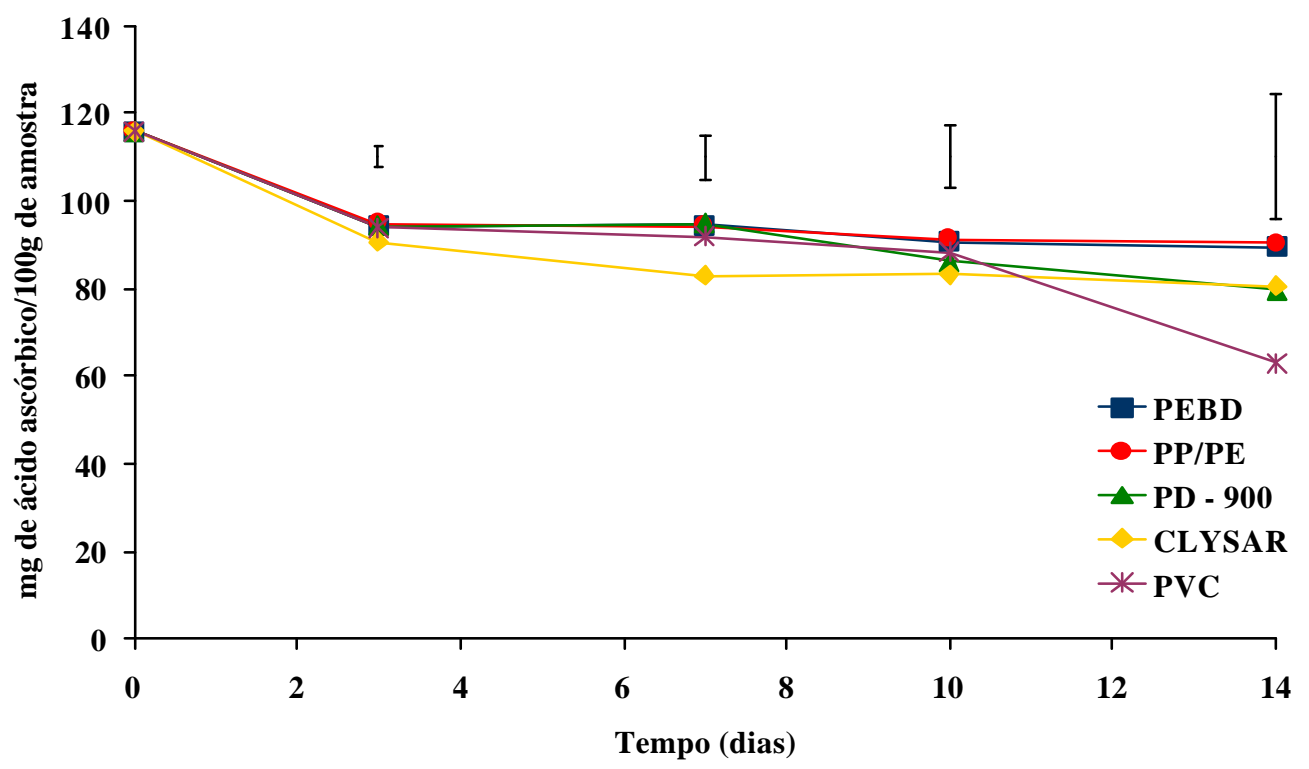

Figura 22 - Vitamina $\mathrm{C}$ das folhas de rúculas nas diferentes embalagens, mantidas a $5^{\circ} \mathrm{C}$ e $85-95 \%$ de umidade relativa. Barras na vertical indicam a diferença mínima significativa (DMS) $(\mathrm{P} \leq 0,05)$. 
Este efeito da atmosfera controlada na manutenção de ácido ascórbico tem sido descrito para alguns produtos, como floretes de brócolos (Barth et al., 1993a; Barth et al., 1993b; Barth \& Zhuang, 1996), morangos e caquis fatiados (Wright \& Kader, 1997).

De acordo com Lee \& Kader (2000), a vitamina C é muito sensível à degradação quando o produto é submetido a condições adversas de manuseio e armazenamento. Perdas são favorecidas por períodos prolongados de armazenamento, altas temperaturas, baixas umidades relativas, danos físicos e distúrbios fisiológicos causados pelo frio. É facilmente oxidada, especialmente em soluções aquosas, na presença de oxigênio, de íons metálicos pesados, especialmente, $\mathrm{Cu}^{2+}, \mathrm{Ag}^{+}$e $\mathrm{Fe}^{3+}$ e em $\mathrm{pH}$ alcalino e altas temperaturas.

Altas concentrações de $\mathrm{O}_{2}$ no interior das embalagens de PVC talvez tenham sido responsáveis pelas maiores perdas de vitamina $\mathrm{C}$ em folhas de rúculas desta embalagem.

Tabela 25. Vitamina C (mg de ácido ascórbico/100 g de amostra) de folhas de rúculas em diferentes embalagens, mantidas a $5^{\circ} \mathrm{C}$ e $85-95 \%$ de umidade relativa.

\begin{tabular}{lcccccc}
\hline Tratamentos & \multicolumn{5}{c}{ mg de ácido ascórbico/100g de folhas de rúculas } \\
& 0 dia & 3 dias & 7 dias & 10 dias & 14 dias & C.V.(\%) \\
\hline PEBD & 115,80 a A & 94,18 a B & 94,31 a B & 90,60 a B & 89,30 a B & 9,24 \\
PP/PE & 115,80 a A & 94,74 a B & 94,24 a B & 91,27 a B & 90,23 a B & 3.71 \\
PD - 900 & 115,80 a A & 94,18 a B & 94,69 a B & 86,15 a B & 79,52 a B & 11,92 \\
CLYSAR & 115,80 a A & 90,62 a B & 82,91 b C & 83,17 a BC & 80,62 a C & 4,04 \\
PVC & 115,80 a A & 93,88 a B & 91,90 ab B & 88,30 a B & 63,05 a D & 6,46 \\
CV (\%) & - & 2,22 & 5,14 & 7,57 & 16,29 & - \\
\hline
\end{tabular}

Médias seguidas da mesma letra minúscula na coluna e maiúscula na linha não diferem entre si, pelo teste de Tukey a 5\% de probabilidade. 


\subsubsection{Coloração}

A coloração das folhas de rúculas nas diferentes embalagens, mantidas a $5^{\circ} \mathrm{C}$ por 14 dias, está expressa em Luminosidade (Figura 23 e Tabela 26), Croma (Figura 24 e Tabela 27) e ângulo Hue (Figura 25 e Tabela 28).

Não houve diferença na luminosidade das folhas de rúculas de cada uma das embalagens até $\mathrm{o} 10^{\circ}$ dia. Porém, no $14^{\circ}$ dia, as folhas do PEBD estavam significativamente com menos luminosidade que as do PVC e ambas não diferiram da luminosidade das demais nas outras embalagens (Figura 23 e Tabela 25).

Ao longo do tempo, as folhas de rúculas em PP/PE, PD - 900 e PVC permaneceram praticamente sem alterações em suas luminosidades até o $7^{\circ}$ dia e as embaladas em PEBD e Clysar, até o $3^{\circ}$ dia (Tabela 26). A partir de então, a luminosidade das folhas aumentou até o $10^{\circ}$ dia e, após, diminuiu até o $14^{\circ}$ dia; significativamente, no caso das folhas em PEBD, PP/PE e Clysar. Esta diminuição nos valores de $L^{*}$ significa que as folhas tenderam a um escurecimento, uma vez que $L^{*}$ varia de 0 (preto) a 100 (branco), passando por 9 cinzas intermediárias (Ferreira, 1991).

Os valores de croma para as folhas de rúculas das diferentes embalagens também foram significativamente iguais em todos os dias de análises (Figura 24 e Tabela 27).

Da mesma forma que para a luminosidade, o croma das folhas em cada embalagem permaneceu estatisticamente igual durante os primeiros 7 dias para aquelas em PEBD, PP/PE, Clysar e PVC e durante 14 dias para as rúculas minimamente processadas em PD -900 . Do $10^{\circ}$ para o $14^{\circ}$ dia, o croma diminuiu significativamente nas folhas em PEBD, PP/PE, Clysar e PVC, significando menor intensidade de coloração verde das folhas (Ferreira, 1981).

O ângulo Hue, pelo qual se distingue uma cor de outra (Ferreira, 1981) mostra que até o $7^{\circ}$ dia de análise, as rúculas apresentavam a mesma cor, independentemente da embalagem em que estavam contidas (Figura 25 e Tabela 28). No $10^{\circ}$ dia, as folhas em PVC estavam significativamente menos verdes que as em PD - 900 e as das demais embalagens, com cores intermediárias a elas. A perda de coloração verde das folhas de 


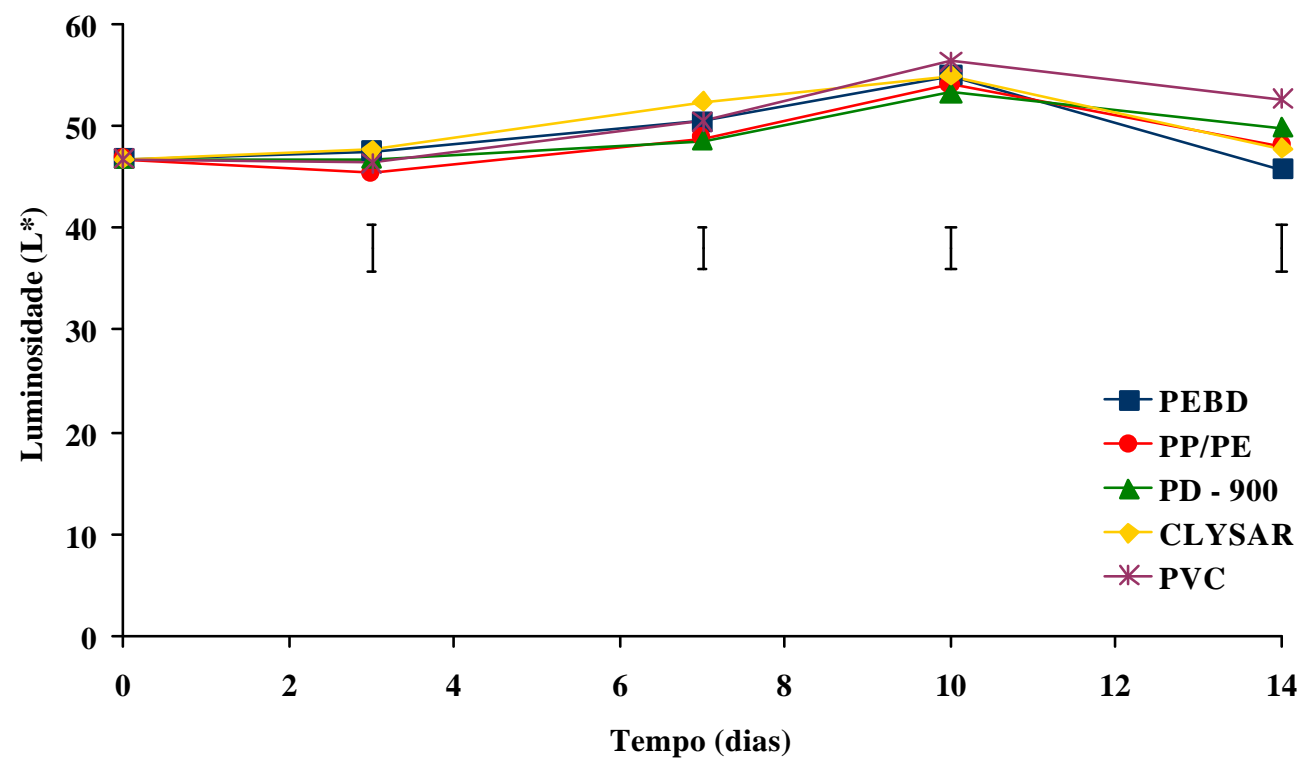

Figura 23 - Valores de luminosidade $\left(\mathrm{L}^{*}\right)$ para as folhas de rúculas nas diferentes embalagens, mantidas a $5^{\circ} \mathrm{C}$ e $85-95 \%$ de umidade relativa. Barras na vertical indicam a diferença mínima significativa (DMS) $(\mathrm{P} \leq 0,05)$.

Tabela 26. Valores de Luminosidade $\left(\mathrm{L}^{*}\right)$ para as folhas de rúculas em diferentes embalagens, mantidas a $5^{\circ} \mathrm{C}$ e $85-95 \%$ de umidade relativa.

\begin{tabular}{lcccccc}
\hline Tratamentos & \multicolumn{5}{c}{ Luminosidade (L*) } \\
& 0 dia & 3 dias & 7 dias & 10 dias & 14 dias & CV(\%) \\
\hline PEBD & 46,69 a C & 47,48 a C & 50,45 a B & 54,84 a A & 45,68 b C & 2,16 \\
PP/PE & 46,69 a B & 45,31 a B & 48,77 a B & 53,99 a A & 47,97 ab B & 3,54 \\
PD - 900 & 46,69 a B & 46,67 a B & 48,49 a B & 53,27 a A & $49,84 a b A B$ & 4,23 \\
CLYSAR & 46,69 a B & 47,65 a B & 52,29 a A & 54,88 a A & 47,84 ab B & 3,24 \\
PVC & 46,69 a C & 46,28 a C & 50,38 a BC & 56,27 a A & 52,64 a AB & 4,66 \\
CV $(\%)$ & - & 4,47 & 3,55 & 3,27 & 4,51 & - \\
\hline
\end{tabular}

Médias seguidas da mesma letra minúscula na coluna e maiúscula na linha não diferem entre si, pelo teste de Tukey a 5\% de probabilidade. 


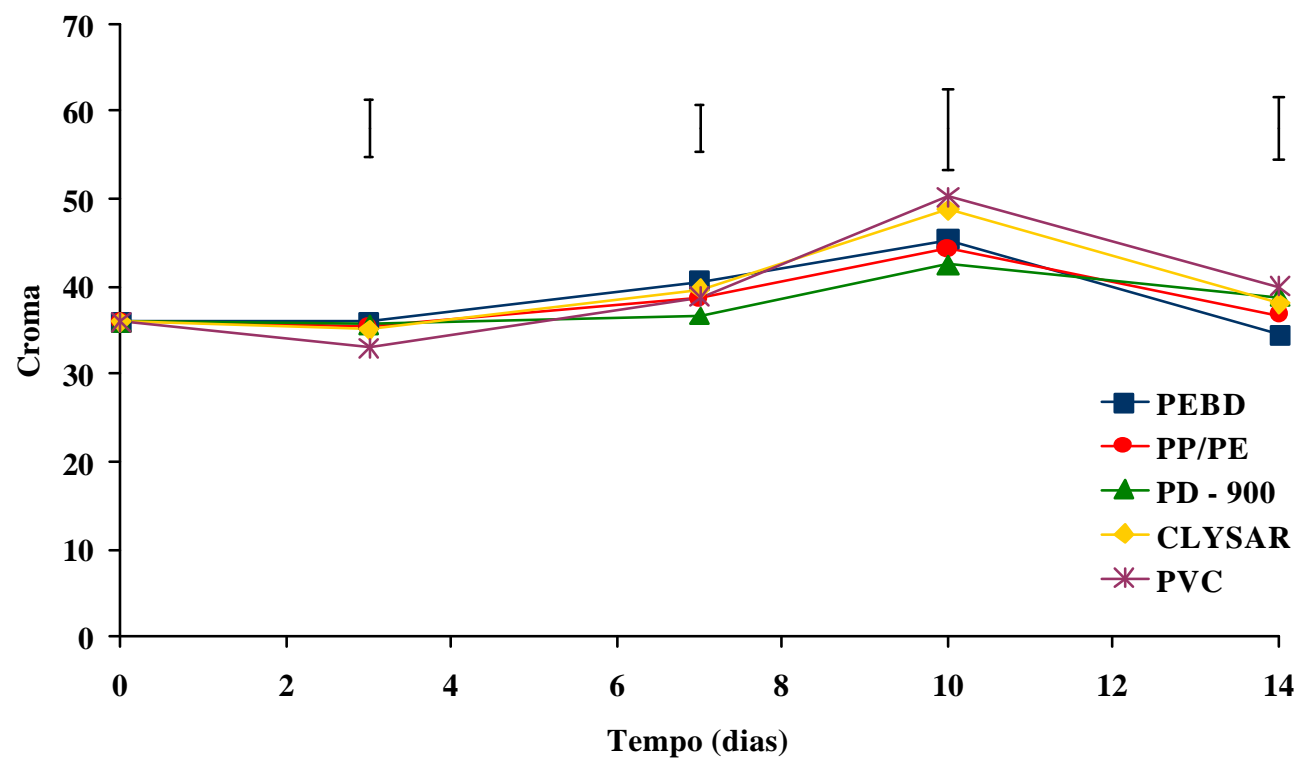

Figura 24 - Valores de Croma para as folhas de rúculas nas diferentes embalagens, mantidas a $5^{\circ} \mathrm{C}$ e $85-95 \%$ de umidade relativa. Barras na vertical indicam a diferença mínima significativa (DMS) $(\mathrm{P} \leq 0,05)$.

Tabela 27. Valores de Croma para as folhas de rúculas em diferentes embalagens, mantidas a $5^{\circ} \mathrm{C}$ e $85-95 \%$ de umidade relativa.

\begin{tabular}{lcccccc}
\hline Tratamentos & \multicolumn{5}{c}{ Croma } \\
& \multicolumn{1}{c}{ 0 dia } & 3 dias & 7 dias & 10 dias & 14 dias & C.V.(\%) \\
\hline PEBD & 35,95 a CB & 36,01 a CB & 40,53 a AB & 45,32 a A & 34,42 a C & 6.43 \\
PP/PE & 35,95 a B & 35,28 a B & 38,67 a AB & 44,34 a A & 36,75 a B & 8.45 \\
PD - 900 & 35,95 a A & 35,68 a A & 36,60 a A & 42,41 a A & 38,78 a A & 9.64 \\
CLYSAR & 35,95 a B & 35,07 a B & 39,63 a B & 48,63 a A & 38,01 a B & 5.87 \\
PVC & 35,95 a B & 32,89 a B & 38,75 a B & 50,18 a A & 40,00 a B & 8.45 \\
C.V. (\%) & - & 8.41 & 6.25 & 9.21 & 8.36 & - \\
\hline
\end{tabular}

Médias seguidas da mesma letra minúscula na coluna e maiúscula na linha não diferem entre si, pelo teste de Tukey a 5\% de probabilidade. 


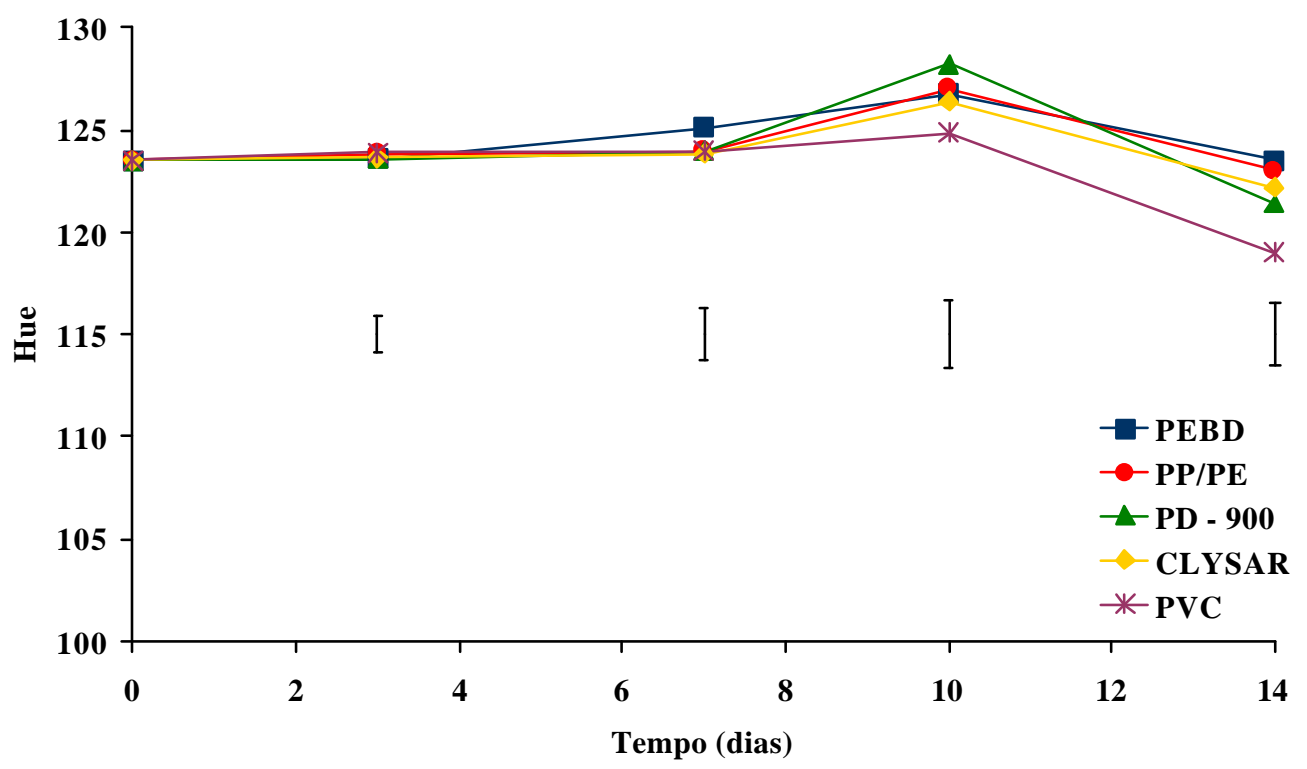

Figura 25 - Valores do ângulo Hue para as folhas de rúculas nas diferentes embalagens, mantidas a $5^{\circ} \mathrm{C}$ e $85-95 \%$ de umidade relativa. Barras na vertical indicam a diferença mínima significativa (DMS) $(\mathrm{P} \leq 0,05)$.

Tabela 28. Valores do ângulo Hue para as folhas de rúculas em diferentes embalagens, mantidas a $5^{\circ} \mathrm{C}$ e $85-95 \%$ de umidade relativa.

\begin{tabular}{lcccccc}
\hline Tratamentos & \multicolumn{5}{c}{ Hue } \\
& \multicolumn{1}{c}{0 dia } & 3 dias & 7 dias & 10 dias & 14 dias & CV $(\%)$ \\
\hline PEBD & 123,50 a B & 123,54 a B & 125,11 a AB & 126,78 ab A & 123,49 a B & 0,77 \\
PP/PE & 123,50 a B & 123,82 a B & 123,98 a B & 127,00 ab A & 123,02 a B & 0,86 \\
PD - 900 & 123,50 a CB & 123,57 a CB & 123,95 a B & 128,23 a A & 121,38 abC & 0,88 \\
CLYSAR & 123,50 a CB & 123,60 a CB & 123,84 a B & 126,36 ab A & 122,15 a C & 0,58 \\
PVC & 123,50 a A & 123,87 a A & 123,97 a A & 124,83 b A & 119,02 b B & 1,33 \\
CV $(\%)$ & - & 0,66 & 0,91 & 1,20 & 1,12 & - \\
\hline
\end{tabular}

Médias seguidas da mesma letra minúscula na coluna e maiúscula na linha não diferem entre si, pelo teste de Tukey a 5\% de probabilidade. 
rúculas em PVC continuou até o $14^{\circ}$ dia, quando se diferenciou significativamente da coloração das demais, porém, não mais das em PD -900, que passou a apresentar uma maior perda de coloração verde, porém não-significativa, em relação às folhas que estavam em PEBD, PP/PE e Clysar HP.

Durante 7 dias a $5^{\circ} \mathrm{C}$, as embalagens de PEBD, PP/PE, PD - 900 e Clysar HP mantiveram a coloração das folhas de rúculas inalteradas. No $10^{\circ}$ dia houve alterações significativas, como se as rúculas tivessem passado de uma coloração verde mais clara para mais escura e no $14^{\circ}$ dia voltaram a ter cores estatisticamente iguais às dos primeiros dias de armazenamento.

As embaladas em PVC mantiveram a cor inicial por 10 dias. Porém, do $10^{\circ}$ para o $14^{\circ}$ dia, foram as que apresentaram maior mudança de coloração e, neste caso, o ângulo Hue diminuiu significativamente, indicando maior perda da coloração verde.

Apesar das alterações significativas nos valores de L*, Croma e Hue, elas aconteceram dentro de uma faixa muito pequena para se afirmar que uma embalagem tenha se destacado na manutenção da coloração verde das folhas de rúculas, no período estudado.

Os resultados obtidos neste estudo vão ao encontro dos de Toivonen (1997) que também não observou efeito da embalagem no amarelecimento de brócolos, porém sim, da temperatura de armazenamento. Carnelossi (2000) relata que couves em PD - 941, a 1 e $5^{\circ} \mathrm{C}$, mantiveram os teores de clorofila total e carotenóides constantes durante 15 dias de armazenamento. Porém, a $10^{\circ} \mathrm{C}$, os teores de clorofila reduziram-se em $23 \%$ até o $10^{\circ}$ dia, quando as couves foram descartadas por estarem deterioradas e com sinais visíveis de senescência. Teles (2001) também não observou alteração de cor em couves em filmes poliolefínicos com atmosfera modificada passiva e ativa.

\subsubsection{Firmeza}

Como esperado, houve uma tendência de decréscimo na firmeza das folhas de rúculas durante os 14 dias de armazenamento a $5^{\circ} \mathrm{C}$ (Figura 26 e Tabela 29). 
Diferenças significativas na firmeza foram notadas aos 7 dias, sendo que as folhas em PEBD apresentaram-se mais firmes que aquelas em Clysar e PVC, mas iguais às das embaladas em PP/PE e PD - 900. Aos 10 dias todas se mostraram igualmente firmes e aos 14 dias, novamente, as contidas em PEBD estavam mais firmes que as demais, com exceção das folhas em PP/PE.

Considerando-se individualmente cada uma das embalagens, observa-se, pela Tabela 29, que as folhas de rúculas em PEBD foram as únicas que mantiveram sua firmeza durante todos os 14 dias de armazenamento a $5^{\circ} \mathrm{C}$.

As folhas em PP/PE e Clysar permaneceram com a firmeza inicial até o $7^{\circ}$ dia e as em PD - 900 somente até o $3^{\circ}$ dia. A partir destes dias, as firmezas diminuíram significativamente nestas embalagens até o $14^{\circ}$ dia.

A pior delas foi a de PVC, na qual a firmeza diferiu estatisticamente da inicial já a partir do $3^{\circ}$ dia. Muito provavelmente, a alta permeabilidade ao vapor d'água de filmes de PVC fez com que as folhas perdessem umidade mais rapidamente e, conseqüentemente, a firmeza.

Berrang et al. (1990) não encontraram efeito significativo de atmosfera controlada nas texturas de floretes de brócolos e de couves-flores. Por outro lado, Kader (1986) relata estudos de outros pesquisadores que ao armazenarem brócolos sob 10\% $\mathrm{CO}_{2}$, a $5^{\circ} \mathrm{C}$, por 2 semanas, observaram que eles estavam mais tenros que os mantidos em atmosfera normal.

Atmosferas controladas também não tiveram efeito na textura de espinafres minimamente processados, armazenados a $5^{\circ} \mathrm{C}$ (Babic \& Watada, 1996).

O mecanismo do efeito de atmosferas controladas na textura de hortaliças parece não ser muito bem compreendido ainda. 


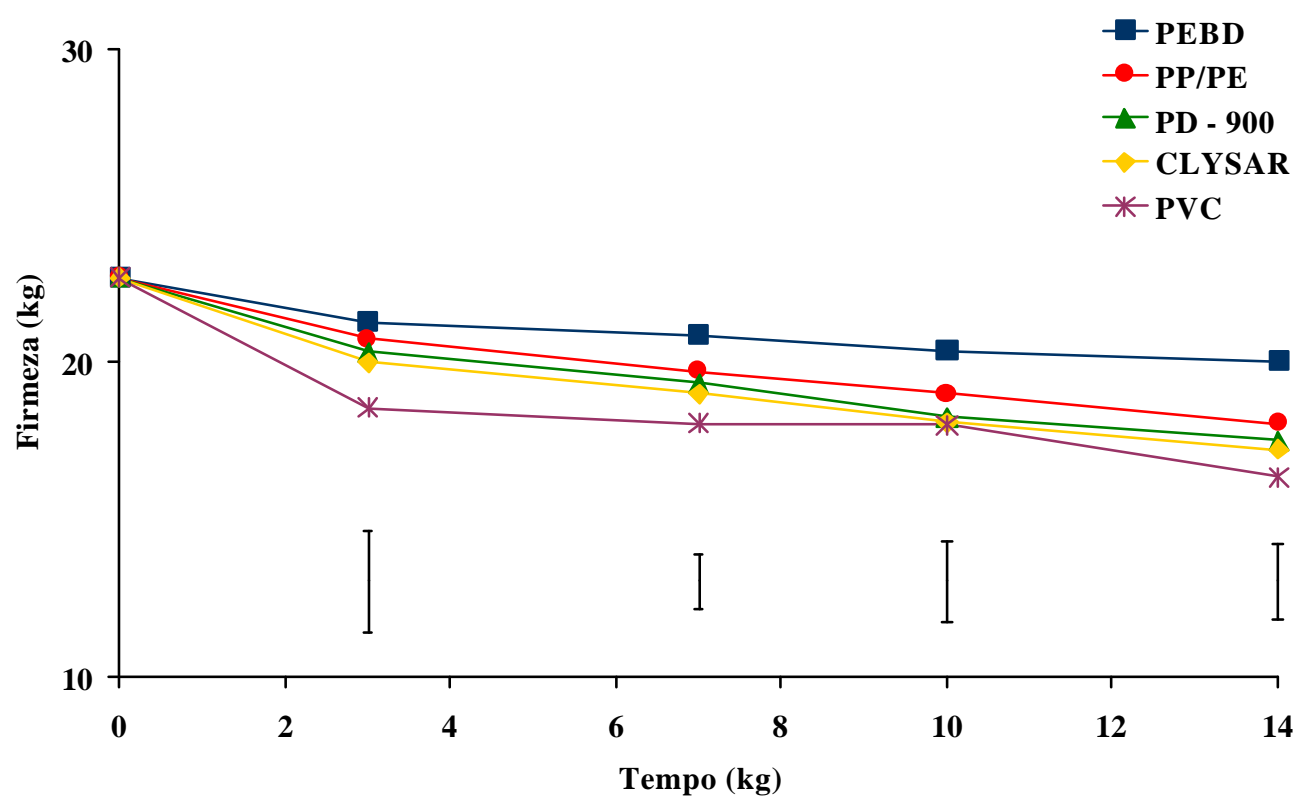

Figura 26 - Valores de firmeza (kg) para as folhas de rúculas nas diferentes embalagens, mantidas a $5^{\circ} \mathrm{C}$ e $85-95 \%$ de umidade relativa. Barras na vertical indicam a diferença mínima significativa (DMS) $(\mathrm{P} \leq 0,05)$.

Tabela 29. Valores de firmeza $(\mathrm{kg})$ para as folhas de rúculas em diferentes embalagens, mantidas a $5^{\circ} \mathrm{C}$ e $85-95 \%$ de umidade relativa.

\begin{tabular}{lcccccc}
\hline Tratamentos & \multicolumn{7}{c}{ Firmeza (kg) } \\
& 0 dia & 2 dias & 7 dias & 10 dias & 14 dias & C.V.(\%) \\
\hline PEBD & 22,71 a A & 21,27 a A & 20,88 a A & 20,37 a A & 20,03 a A & 19,86 \\
PP/PE & 22,71 a A & 20,76 a AB & 19,71 abAB & 19,00 a B & 18,06 ab B & 16,80 \\
PD - 900 & 22,71 a A & 20,31 a AB & $19,32 \mathrm{abBC}$ & 18,27 a BC & 17,49 b C & 13,08 \\
CLYSAR & 22,71 a A & 19,99 a AB & 19,02 bAB & 18,06 a B & 17,22 b B & 14,48 \\
PVC & 22,71 a A & 18,54 a B & 18,05 b B & 17,99 a B & 16,35 b B & 17,27 \\
CV $(\%)$ & - & 14,15 & 7,82 & 12,04 & 11,44 & \\
\hline
\end{tabular}

Médias seguidas da mesma letra minúscula na coluna e maiúscula na linha não diferem entre si, pelo teste de Tukey a 5\% de probabilidade. 


\subsubsection{Análises microbiológicas}

Análise realizada logo após o processamento mínimo não detectou a presença de Salmonella spp, estando as rúculas minimamente processadas de acordo com a Resolução RDC 12 (Agência Nacional de Vigilância Sanitária, 2001) que estabelece ausência deste microrganismo em $25 \mathrm{~g}$ de amostra.

Também apresentaram condições higiênico-sanitárias em termos de coliformes fecais (Escherichia coli), as folhas de rúculas de todas as embalagens, durante os 14 dias de armazenamento a $5^{\circ} \mathrm{C}$, uma vez que suas contagens estiveram sempre abaixo do limite de deteç̧ão, isto é, menor que $10 \mathrm{UFC/g}$ de produto. De acordo com a Agência Nacional de Vigilância Sanitária (2001), a contagem máxima de coliformes fecais permitida é de $1,0 \times 10^{2} \mathrm{UFC} / \mathrm{g}$ de produto.

Com relação a coliformes totais, a rúcula só manteve a contagem inicial até o $3^{\circ}$ dia de análise para as folhas mantidas em PEBD. Nas demais embalagens, houve um aumento considerável de 3 ciclos logarítmicos (Tabela 30).

No $7^{\circ}$ dia, as folhas de todas as embalagens apresentaram 3 ciclos logarítmicos de coliformes totais, passando a 5 ciclos no $10^{\circ}$ dia, considerado nível bastante elevado e que limita seu consumo (Guerzoni et al., 1996).

Apesar de contaminação de coliformes totais de $10^{5} \mathrm{UFC} / \mathrm{g}$ de produto, as folhas não se apresentaram com aspecto de deterioradas.

Quanto ao nível de bolores e leveduras, todas as embalagens mantiveram contagens baixas, como as iniciais $\left(k 10^{2}\right)$, durante os 14 dias de armazenamento a $5^{\circ} \mathrm{C}$ (Tabela 31).

Geralmente, a modificação da atmosfera no interior das embalagens, associada a baixas temperaturas pode inibir o desenvolvimento de alguns microrganismos deterioradores, como é o caso de bolores, leveduras e coliformes fecais (Daniels et al., 1985 \& Farber, 1991), porém, no presente estudo, atmosferas controladas não tiveram efeito significativo no controle de microrganismos em aspargos e couves-flores (Berrang et al., 1990). 
$\mathrm{Na}$ verdade, os efeitos potenciais da tecnologia de atmosfera modificada, no crescimento e sobrevivência de patógenos ainda são muito pouco conhecidos (Francis et al., 1999).

Tabela 30. Contagem de coliformes totais em rúculas minimamente processadas em diferentes embalagens, mantidas a $5^{\circ} \mathrm{C}$ e $85-95 \%$ de umidade relativa.

\begin{tabular}{lccccc}
\hline \multirow{2}{*}{ Tratamentos } & \multicolumn{4}{c}{ Coliformes Totais (UFC/g) } \\
& 0 dia & 3 dias & 7 dias & 10 dias & 14 dias \\
\hline PEBD & $<10$ & $<10$ & $1,8 \times 10^{3}$ & $1,8 \times 10^{5}$ & $1,8 \times 10^{6}$ \\
PP/PE & $<10$ & $1,4 \times 10^{3}$ & $2,1 \times 10^{3}$ & $2,1 \times 10^{5}$ & $2,1 \times 10^{6}$ \\
PD - 900 & $<10$ & $2,6 \times 10^{3}$ & $2,8 \times 10^{3}$ & $2,8 \times 10^{5}$ & $2,8 \times 10^{6}$ \\
CLYSAR HP & $<10$ & $2,3 \times 10^{3}$ & $3,9 \times 10^{3}$ & $3,9 \times 10^{5}$ & $3,9 \times 10^{6}$ \\
PVC 20 $\mu \mathrm{m}$ & $<10$ & $1,2 \times 10^{3}$ & $2,8 \times 10^{3}$ & $2,8 \times 10^{5}$ & $2,8 \times 10^{6}$
\end{tabular}

* UFC/g = Unidades Formadoras de Colônias por grama de produto.

Tabela 31. Contagem de bolores e leveduras em floretes de diferentes embalagens, mantidos a $5^{\circ} \mathrm{C}$ e $85-95 \%$ de umidade relativa.

\begin{tabular}{|c|c|c|c|c|c|}
\hline \multirow{2}{*}{ Tratamentos } & \multicolumn{5}{|c|}{ Bolores e Leveduras (UFC/g) } \\
\hline & 0 dia & 3 dias & 7 dias & 10 dias & 14 dias \\
\hline PEBD & $<10^{2}$ & $<10^{2}$ & $<10^{2}$ & $<10^{2}$ & $<10^{2}$ \\
\hline$P D-941$ & $<10^{2}$ & $<10^{2}$ & $<10^{2}$ & $<10^{2}$ & $<10^{2}$ \\
\hline CLYSAR AFG & $<10^{2}$ & $<10^{2}$ & $<10^{2}$ & $<10^{2}$ & $<10^{2}$ \\
\hline PVC $12 \mu \mathrm{m}$ & $<10^{2}$ & $<10^{2}$ & $<10^{2}$ & $<10^{2}$ & $<10^{2}$ \\
\hline PVC $20 \mu \mathrm{m}$ & $<10^{2}$ & $<10^{2}$ & $<10^{2}$ & $<10^{2}$ & $<10^{2}$ \\
\hline
\end{tabular}

* UFC/g = Unidades Formadoras de Colônias por grama de produto. 


\subsubsection{Análise sensorial}

Os resultados da análise sensorial estão apresentados nas Figuras 27a 32.

Em termos de aparência geral, considerando-se o conjunto embalagem + folhas de rúculas, a que mais sobressaiu foi o saco de PEBD. No $10^{\circ}$ dia, quando o nível de microrganismos já era elevado, limitando o consumo das rúculas, esta embalagem juntamente com as folhas obteve nota superior a 4 (boa). A aparência do conjunto PVC + folhas de rúculas obteve nota 3 (regular) neste mesmo dia, sendo que os demais conjuntos oscilaram entre regular a bom (Figura 27).

Até o $10^{\circ}$ dia de armazenamento a $5^{\circ} \mathrm{C}$, nenhuma das embalagens apresentou odor estranho caracterizado como moderado (nota 3), no momento de sua abertura (Figura 28). Novamente, a PEBD foi a melhor, pois, quando aberta no $10^{\circ}$ dia, possuía um leve odor estranho.

Com relação à qualidade global das rúculas minimamente processadas, aquelas em PEBD e PP/PE foram as que melhores notas receberam até o $10^{\circ}$ dia, sendo consideradas "boas", com nota igual ou bem próxima de 4 (Figura 29).

A embalagem de PVC, devido à sua alta permeabilidade ao vapor d'água, fez com que as folhas murchassem mais rapidamente. No $10^{\circ}$ dia, as rúculas já mostravam sinais de moderado murchamento, enquanto as das outras embalagens receberam pouco mais que nota 2 (levemente murchas) (Figura 30).

Quanto a sinais visíveis de deterioração, as folhas em PEBD e PP/PE também foram as que obtiveram as melhores notas, próximas a 1 (deterioração ausente). As demais, próximas a 2 (leve deterioração), no $10^{\circ}$ dia de avaliação (Figura 31)

Houve, ao longo do período de armazenamento, uma tendência de perda da coloração verde das folhas, porém, no $10^{\circ}$ dia, estavam com cor verde-clara (Figura 32). As em PVC obtiveram notas sempre maiores às das demais quanto a este atributo de qualidade.

De modo geral, as embalagens de PEBD e PP/PE foram as melhores em termos de manutenção da qualidade das rúculas minimamente processadas, até $0 \quad 10^{\circ}$ dia, quando a contagem de coliformes totais atingiu níveis bastante elevados (Tabela 30). 


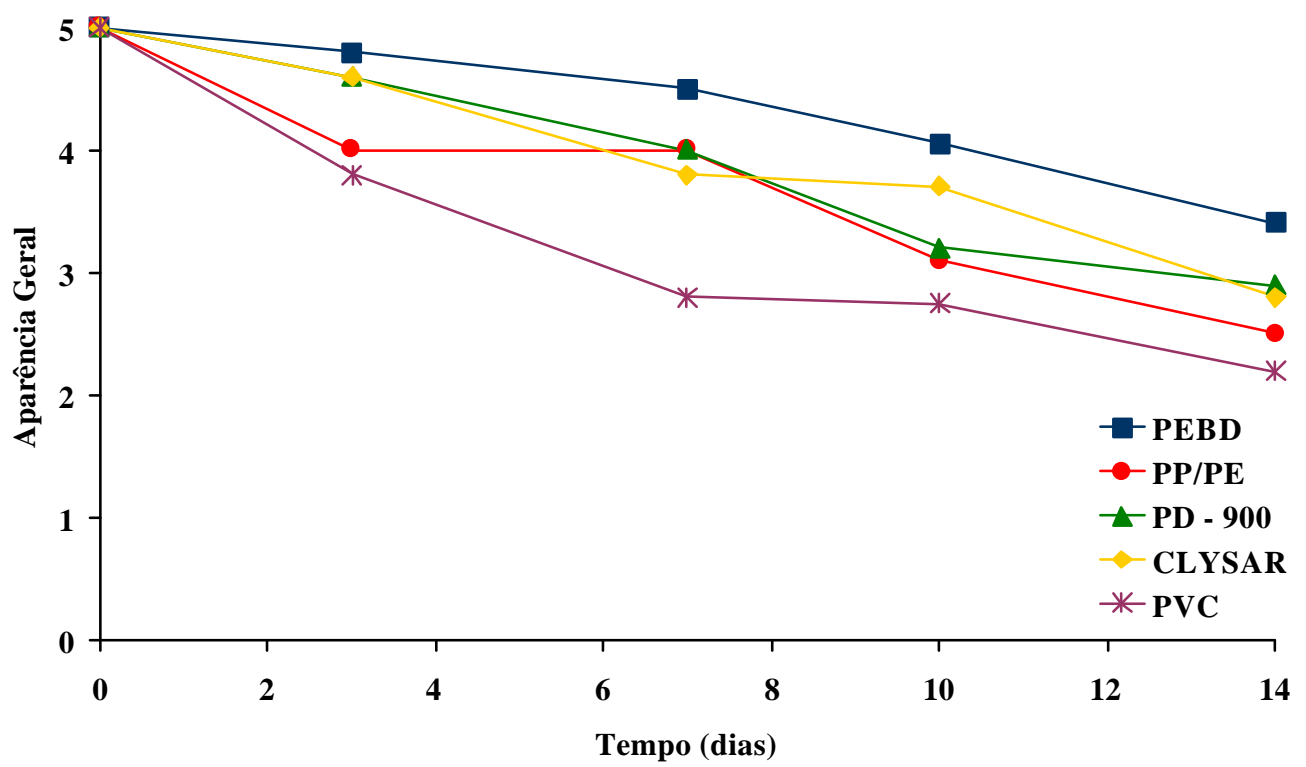

Figura 27 - Aparência geral do conjunto embalagem + rúculas minimamente processadas. (5=excelente; 4=boa; 3=regular; 2=ruim; 1=péssima)

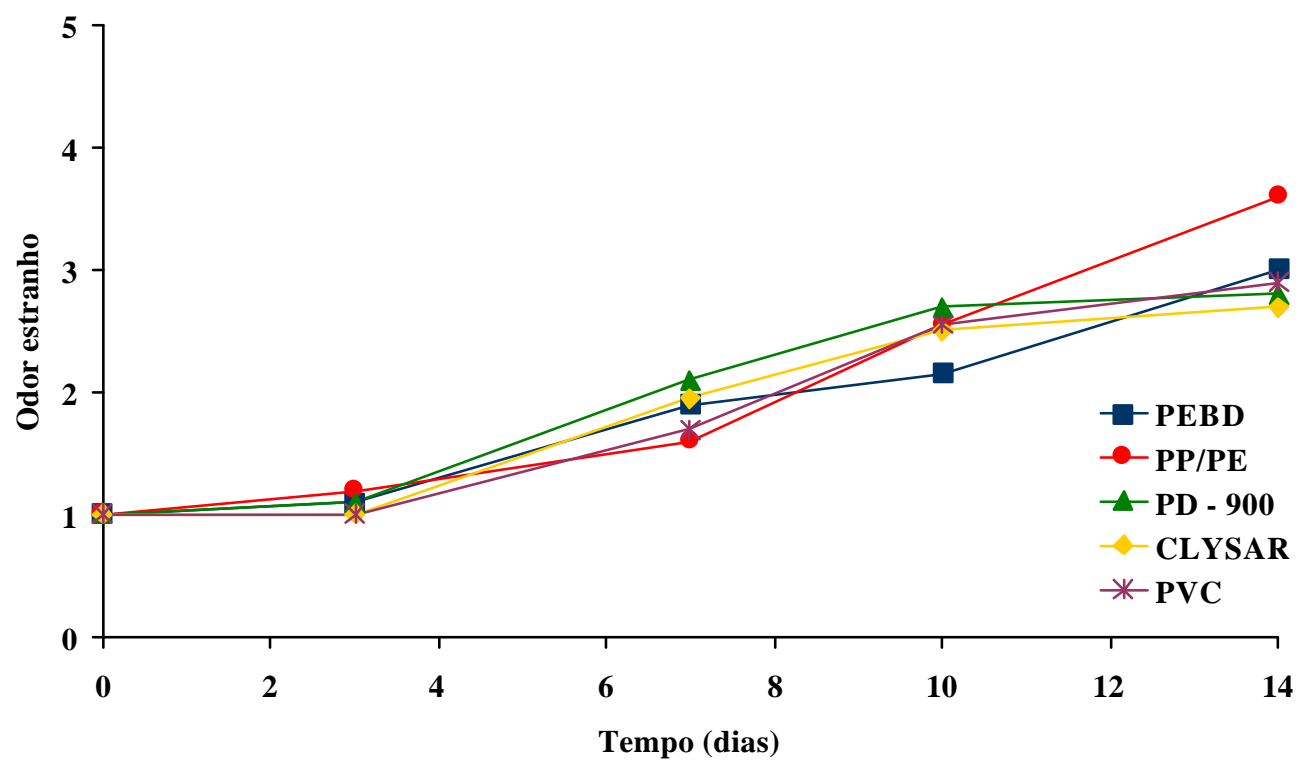

Figura 28 - Odor estranho no momento da abertura das embalagens de rúculas minimamente processadas. (1=ausente; 2=leve; 3=moderado; 4=intenso; $5=$ muito intenso). 


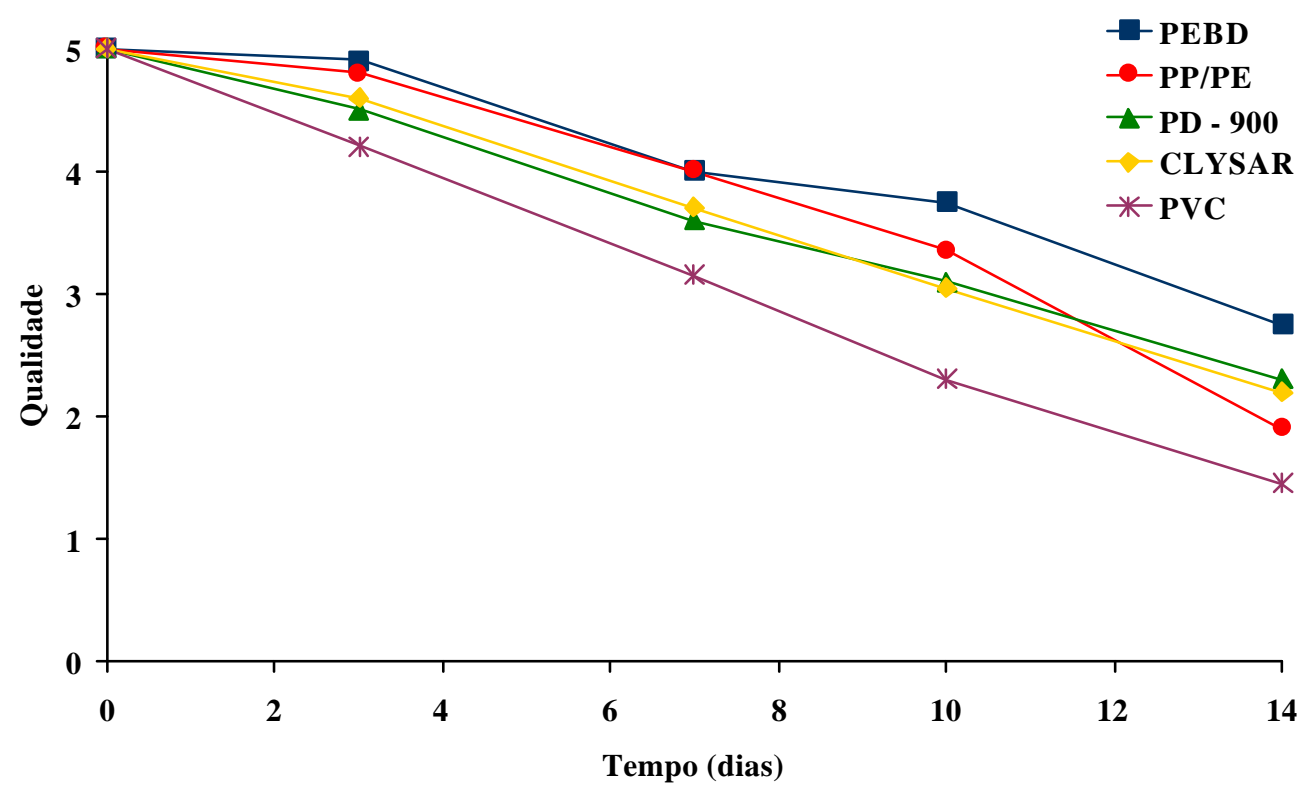

Figura 29 - Qualidade geral das folhas de rúculas nas diferentes embalagens armazenadas a $5^{\circ} \mathrm{C}$ e $85-95 \%$ de umidade relativa. (5=excelente; 4=boa; $3=$ =regular; 2=ruim; 1=péssima).

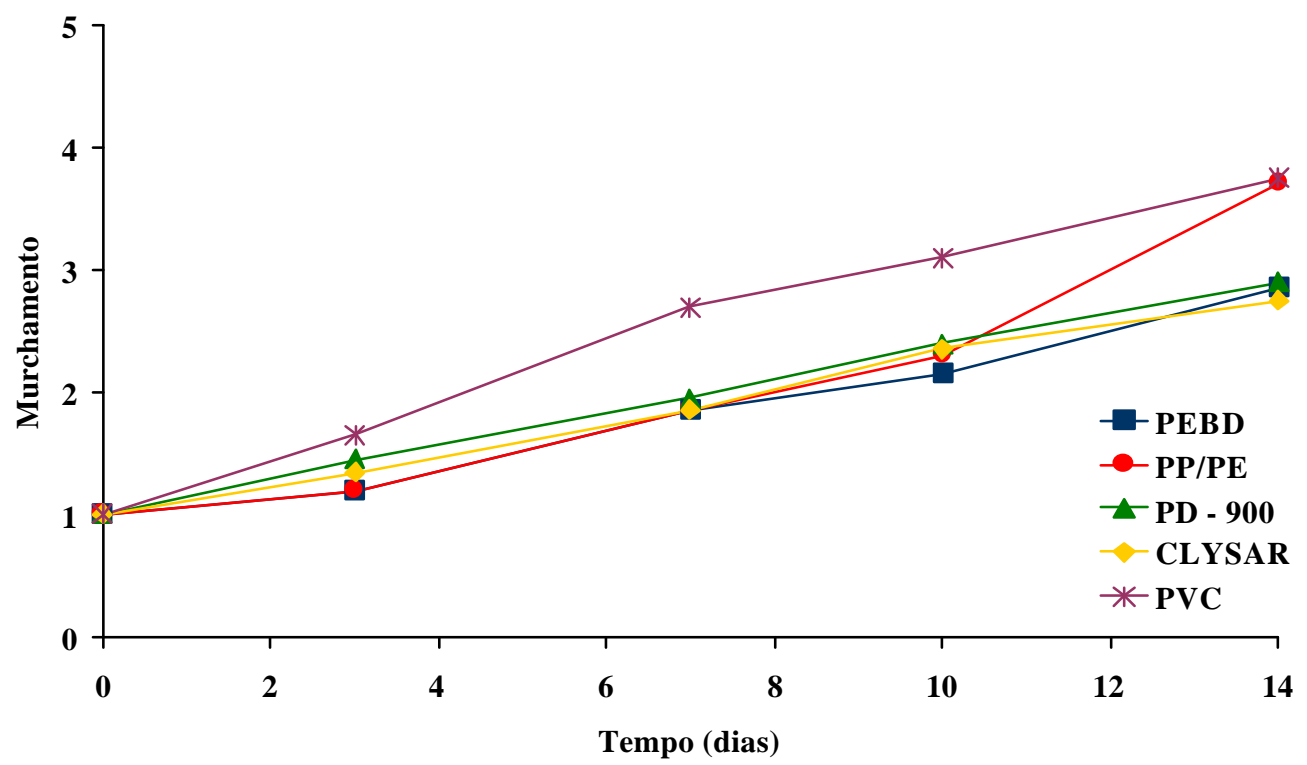

Figura 30 - Murchamento das folhas de rúculas nas diferentes embalagens e armazenadas a $5^{\circ} \mathrm{C}$ e $85-95 \%$ de umidade relativa. (1=ausente; $2=$ leve; $3=$ moderado; 4=intenso; 5=muito intenso). 


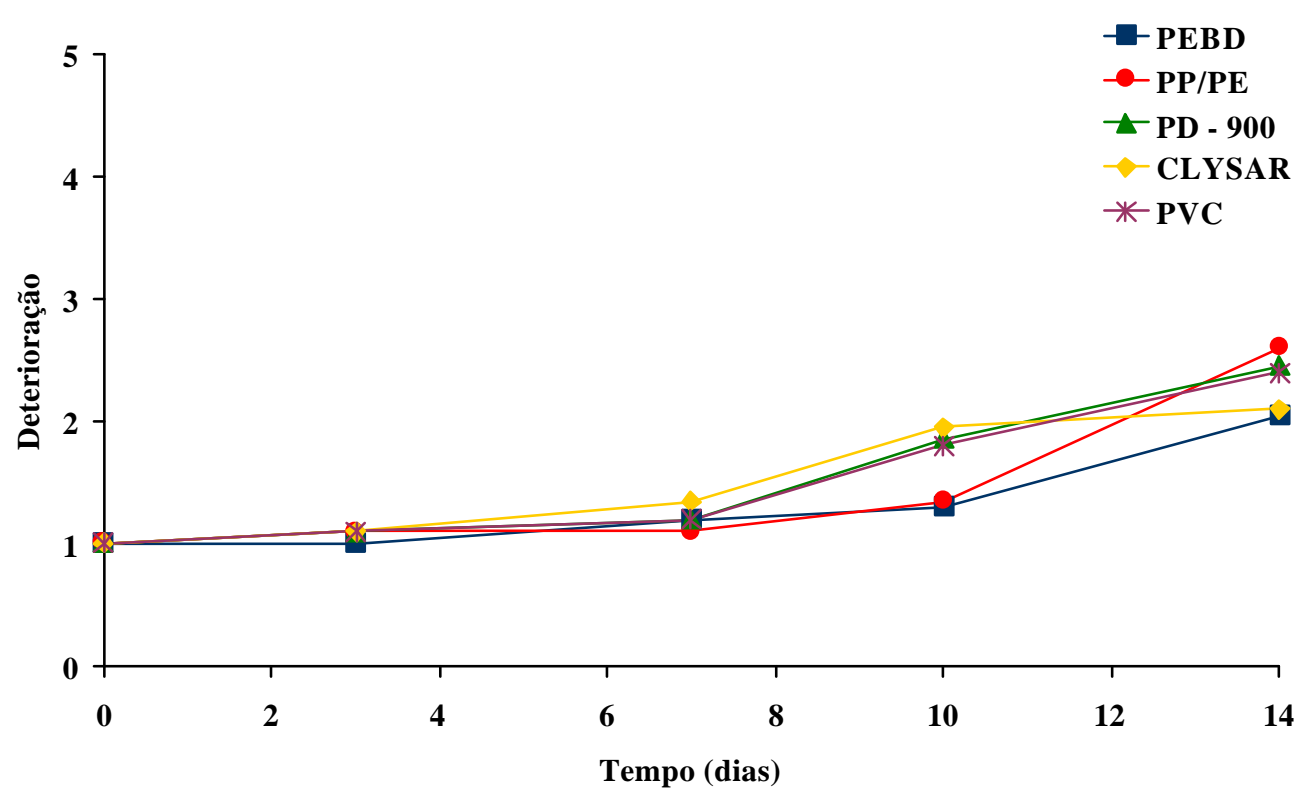

Figura 31 - Deterioração das folhas de rúculas nas diferentes embalagens e armazenadas a $5^{\circ} \mathrm{C}$ e $85-95 \%$ de umidade relativa. (1=ausente; $2=$ leve; $3=$ moderada; 4=intensa; $5=$ muito intensa).

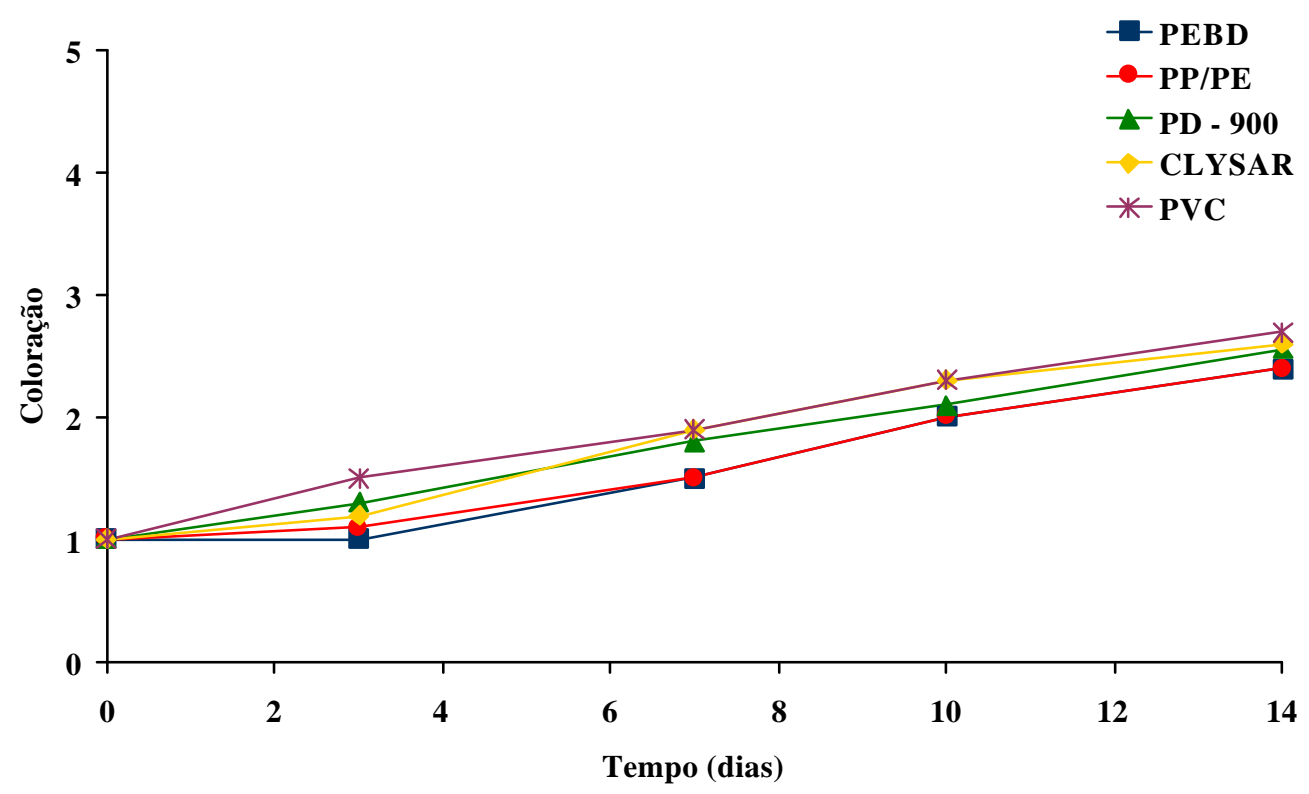

Figura 32 - Coloração das folhas de rúculas nas diferentes embalagens e armazenadas a $5^{\circ} \mathrm{C}$ e $85-95 \%$ de umidade relativa. (1=verde; $2=$ verde-clara; $3=$ verdeamarelada; 4=amarela-esverdeada; 5=amarela). 
Quando se observa as Figuras 17 e 18, nota-se que os teores de $\mathrm{O}_{2}$ e $\mathrm{CO}_{2}$ estão ao redor de $5 \%$ e 10\%, respectivamente, principalmente para as embalagens de PEBD. Concentrações superiores a $7 \% \mathrm{CO}_{2}$ e ao redor de $5 \%$ de $\mathrm{O}_{2}$ são recomendadas para a manutenção da qualidade e da coloração verde de agrião (Vallespir, 1993), outra hortaliça que amarelece e murcha muito rapidamente, como a rúcula.

\section{4 Conclusões}

o filme de PVC foi o único que apresentou atmosfera de equilíbrio para $\mathrm{O}_{2}$ e $\mathrm{CO}_{2}$; os demais atingiram equilíbrio somente para $\mathrm{CO}_{2}$;

as atmosferas desenvolvidas no interior das embalagens influenciaram muito pouco o $\mathrm{pH}$, a acidez, o teor de sólidos solúveis e vitamina $\mathrm{C}$ das rúculas minimamente processadas, sendo que nos filmes de PEBD e PP/PE houve menores perdas de substrato $\left({ }^{\circ}\right.$ Brix) e de vitamina $\mathrm{C}$;

$>$ as embalagens tiveram pouco ou nenhum efeito na perda da coloração verde das folhas de rúculas;

o filme de PEBD é o mais apropriado para a manutenção da firmeza das rúculas minimamente processadas;

em todas as embalagens estudadas, os coliformes totais atingiram, no $10^{\circ}$ dia, níveis considerados elevados para o consumo;

$>$ as folhas de rúculas, em embalagens de PEBD e PP/PE, foram as que atingiram as melhoras notas para vários dos atributos de qualidade avaliados sensorialmente;

atmosferas ao redor de $5-7 \% \mathrm{O}_{2}$ e $10-15 \% \mathrm{CO}_{2}$ são as que melhor conservam rúculas minimamente processadas a $5^{\circ} \mathrm{C}$. 


\section{CONCLUSÕES GERAIS}

floretes de couves-flores devem ser mantidos a $1^{\circ}$ ou $5^{\circ} \mathrm{C}$;

a $11^{\circ} \mathrm{C}$, o metabolismo (taxa respiratória) dos floretes é o dobro $\left(\mathrm{Q}_{10}=2,1\right)$ daqueles mantidos a $1^{\circ} \mathrm{C}$;

folhas soltas de rúculas devem ser mantidas a $5^{\circ} \mathrm{C}$;

a $11^{\circ} \mathrm{C}$, seu metabolismo (taxa respiratória) é quase 6 vezes maior $\left(\mathrm{Q}_{10}=5,74\right)$ que a $1{ }^{\circ} \mathrm{C}$;

a $11^{\circ} \mathrm{C}$, as folhas começam a amarelecer a partir do $2^{\circ}$ dia, tornando-se completamente amarelas no $6^{\circ}$ dia ;

$>$ as embalagens de PD - 941 e PEBD foram as que melhor mantiveram a qualidade dos floretes de couves-flores durante 14 dias a $5^{\circ} \mathrm{C}$;

a embalagem de PD - 941 foi a que desenvolveu a atmosfera modificada mais próxima à recomendada para couves-flores, qual seja, 2-3\% $\mathrm{O}_{2}$ e $\mathrm{CO}_{2}<5 \%$;

$>$ as folhas de rúculas em PEBD e PP/PE mantiveram-se com melhor qualidade que nas demais embalagens, até o $10^{\circ}$ dia a $5^{\circ} \mathrm{C}$;

$>$ atmosferas de $5-7 \% \mathrm{O}_{2}$ e $10-15 \% \mathrm{CO}_{2}$, desenvolvidas no interior das embalagens de PEBD e PP/PE, são as melhores para conservação de folhas de rúculas a $5^{\circ} \mathrm{C}$. 


\section{REFERÊNCIAS BIBLIOGRÁFICAS}

ABE, K.; WATADA, A.E. Ethylene absorbent to maintain quality of lightly processed fruits and vegetables. Journal of Food Science, v.56, n.6, p.1589-1592, Nov-Dec. 1991.

ABELES, F.B; MORGAN, P.W.;SALTVEIT JUNIOR., M.E. Ethylene in plant biology. 2. ed. San Diego, California: Academic Press, 1992. 414p.

AGÊNCIA NACIONAL DE VIGILÂNCIA SANITÁRIA Resolução - RDC n.12, de 02 de janeiro de 2001. In: SILVA, N.; JUNQUEIRA, V.C.A.; SILVEIRA, N.F.A. Manual de métodos de análise microbiológica de alimentos. 2.ed. São Paulo: Livraria Varela., 2001, p.269-297.

ARTÉS, F.; MARTÍNEZ, J.A. Quality of cauliflower as influenced by film wrapping during shipment. European Food Research and Technology, v.209, n.5, p.330334, 1999.

BABIC, I.; WATADA, A.E. Microbial populations of fresh-cut spinach leaves affected by controlled atmospheres. Postharvest Biology and Technology, v.9, n.2, p.187193, Nov. 1996.

BALDWIN, E.A.; NISPEROS-CARRIEDO, M.O.; BAKER, R.A. Use of edible coatings to preserve quality of lightly (and slightly) processed products. Critical Reviews in Food Science and Nutrition, v.35, n.6, p.509-524, 1995. 
BARTH, M.M.; KERBEL, E.L.; PERRY, A.K.; SCHMIDT, S.J. Modified atmosphere packaging affects ascorbic acid, enzime activity and market quality of broccoli. Journal of Food Science, v. 58, n.1, p.140-143, 1993a.

BARTH, M.M.; KERBEL, E.L.; BROUSSARD, S.; SCHMIDT, S.J. Modified atmosphere packaging protects market quality in broccoli spears under ambient temperature storage. Journal of Food Science, v. 58, n.5, p.1070-1072, 1993 b.

BARTH, M.M.; ZHUANG, H. Packaging design affects antioxidant vitamin retention and quality of broccoli florets during postharvest storage. Postharvest Biology and Technology, v.9, n.2, p.141-150, Nov. 1996.

BASTRASH, S.; MAKHLOUF, J.; CASTAIGNE, F.; WILlEMOT, C. Optimal controlled atmosphere conditions for storage of broccoli florets. Journal of Food Science, v.58, n.2, p.338-341, 360, Mar./Apr.,1993

BEHRSING, J.P; TOMKINS, R.B.;HUTCHIN, J.M.; FRANZ, P. Effect of temperature and size reduction on respiratory activity and shelf-life of vegetables. Acta Horticulturae, v.464, p.500, 1998.

BERRANG, M.E.; BRACKETT, R.E.; BEUCHAT, L.R. Microbial, color and textural qualities of fresh asparagus, broccoli, and cauliflower stored under controlled atmosphere. Journal of Food Protection, v.53, n.5, p.391-395, May 1990.

BEUCHAT, L.R. Pathogenic microorganisms associated with fresh produce. Journal of Food Protection, v.59, n.2, p.204-216,1996.

BIALE, J.B. Respiration of fruits. In: RUKLAND, W.(Ed.) Handbuch der Pfanzenphysiologie. Berlin: Springer-Verlag, 1960. v.12, n.2, p.536-592. 
BLANCO, M.C.S.G.; GROPPO, G.A.; TESSARIOLI NETO, J. Couve-flor Brassica oleracea L. var. botrytis L.). In: COORDENADORIA DE ASSISTÊNCIA TÉCNICA INTEGRAL - CATI (Ed.) Manual técnico das culturas. 2.ed. Campinas: CATI, 1997. v.2, p.57-61.

BOLIN, H.R.; HUXSOLL, C.C. Control of minimally processed carrot (Daucus carota) surface discoloration caused by abrasion peeling. Journal of Food Science, v.56, n.2, p.416-418, 1991.

BRACKETT, R.E. Microbiological consequences of minimally processed fruits and vegetables. Journal of Food Quality, v.10, n.3, p.195-206, 1987.

BRECHT, J.K. Physiology of lightly processed fruits and vegetables. HortScience, v.30, n.1, p.18-22, Feb. 1995.

BUDU, A.S.; JOYCE, D.C.; AKED, J.; THOMPSON, A.K. Respiration of intact and minimally processed pineapple fruit. Tropical Science, v.41, p.119-125, 2001.

CALBO, A.G. Adaptação de um fluxcentro para estudos de trocas gasosas e um método de aferição de capilares. Pesquisa Agropecuária Brasileira, v.24, n.6, p.733-739, Jun. 1989.

CANTWELL, M. Postharvest handling systems: minimally processed fruits and vegetables. In: KADER, A.A. (Ed.) Postharvest technology of horticultural crops. Oakland, California: University of California, 1992. cap.32, p.277-281.

CARLIN, F.; NGUYEN-THE, C.; CHAMBROY, Y.; REICH, M. Effects of controlled atmospheres on microbial spoilage, electrolyte leakage and sugar content of fresh, "ready-to-use" grated carrots. International Journal of Food Science and Technology, v.25, n.1, p.110-119, Feb. 1990. 
CARNELOSSI, M.A.G. Fisiologia pós-colheita de folhas de couve (Brassica oleracea cv. acephala) minimamente pocessadas. Viçosa, 2000. 81p. Tese (Doutorado) Universidade Federal de Viçosa.

CARVALHO, C.R.L.; MANTOVANI, D.M.B.; CARVALHO, P.R.N.; MORAES, R.M.M. Análises químicas de alimentos. Campinas: ITAL, 1990. 121p. (ITAL. Manual Técnico).

CHANES, J. W.; BALDERAS, F. V.; MALO, A. L. Minimally processed foods - state of the art and future. In: FITO, P.; RODRÍGUEZ, E. O.; CÁNOVAS, G. V. (Ed). Food Engineering 2000. New York, NY: Chapman \& Hall, 1997, cap. 11, p. 181212.

CLAYPOOL, L.L.; KEEFER, R.M. A colorimetric method for $\mathrm{CO}_{2}$ determination. Proceedings of the American Society for Horticultural Science, v.40, p.177-186, 1942.

COMPANHIA DE ENTREPOSTOS E ARMAZÉNS GERAIS DE SÃO PAULO. Qüinquênio - preços médios e quantidades mensais: couve-flor. São Paulo, [2002a]. (Comunicação pessoal).

COMPANHIA DE ENTREPOSTOS E ARMAZÉNS GERAIS DE SÃO PAULO. Qüinquênio - preços médios e quantidades mensais: rúcula. São Paulo, [2002b]. (Comunicação pessoal).

DANIELS, J.A.; KRISHNAMURTHI, R.; RIZVI, S.S.H. A review of the effect of carbon dioxide on microbial growth and food quality. Journal of Food Protection, v.48, n.5, p.532-537, May 1985. 
FARBER, J.M. Microbiological aspects of modified atmosphere packaging technology: a review. Journal of Food Protection, v.54, n.1, p.58-70, Jan. 1991.

FERREIRA, V.L.P. Princípios e aplicações da colorimetria em alimentos. Campinas: ITAL, 1981. 85p. (ITAL. Instruções Técnicas, 19).

FNP CONSULTORIA \& COMÉRCIO. Agrianual 2000: Anuário da agricultura brasileira. São Paulo, 2000. p.34-45.

FRANCIS, G.A.; THOMAS, C.; O'BEIRNE, D. The microbiological safety of minimally processed vegetables. International Journal of Food Science and Technology, v.34, n.1, p.1-22, Feb. 1999.

GARG, N.; CHUREY, J. J.; SPLITTSTOESSER, D. F. Microflora of fresh cut vegetables stored at refrigerated and abuse temperatures. Journal Food Science Technology, v.30, n.5, p.385-386, 1993.

GIANNUZZI, L.; RODRIGUEZ, N.; ZARITZKY, N.E. Influence of packaging film permeability and residual sulphur dioxide on the quality of pre-peeled potatoes. International Journal of Food Science and Technology, v.23, n.2, p.147-152, Apr. 1988.

GIL, M.I.; CONESA, M.A.; ARTÉS, F. Quality changes in fresh cut tomato as affected by modified atmosphere packaging. Postharvest Biology and Technology, v.25, n.2, p.199-207, June 2002.

GIL, M.I.; FERRERES, F.; TOMÁS-BARBERÁN, F.A. Effect of modified atmosphere packaging on the flavonoids and vitamin $\mathrm{C}$ content of minimally processed swiss chard (Beta vulgaris Subspecies cycla). Journal of Agricultural and Food Chemistry, v.46, n.5, p.2007-2012, May 1998. 
GORNY, J.R.; HESS-PIERCE, B.; KADER, A.A. Effects of fruit ripeness and storage temperature on the deterioration rate of fresh-cut peach and nectarine slices. HortScience, v.33, n.1, p.110-113, Feb. 1998.

GRINBAUM, R.; FERNANDES, F. Prato pronto amplia vendas e menu. Folha de São Paulo. Folha Negócios, São Paulo, 15 jun. 1998. p.1.

GUERZONI, M.E.; GIANOTTI, A.; CORBO, M.R.; SINIGAGLIA, M. Shelf-life modelling for fresh-cut vegetables. Postharvest Biology and Technology, v.9, n.2, p.195-207, Nov. 1996.

HARDENBURG, R.E.; WATADA, A.E.; WANG, C. Y. The commercial storage of fruits, vegetables, and florist and nursery stocks. Betsville, MD: U.S. Department of Agriculture. 1986. 136p. (Agriculture Handbook, 66)

HEATON, J.W.; LENCKI, R.W.; MARANGONI, A.G. Kinetic model for chlorophyll degradation in green tissue. Journal of Agricultural and Food Chemistry, v.44, n.2, p.399-402, 1996.

HEILAND, W.K.; KONSTANCE, R.P.; CRAIG JUNIOR, J.C. Robotic high pressure water jet cutting of chunk slices. Journal of Food Process Engineering, v.12, n.2, p.131-136, Feb. 1990.

HILDEBRAND, D.F. Lipoxygenases. Physiologia Plantarum, v.76, n.2, p.249-253, Jun. 1989.

HOLCROFT, D.M.; KADER, A.A. Controlled atmosphere-induced changes in $\mathrm{pH}$ and organic acid metabolism may affect color of stored strawberry fruit. Postharvest Biology and Technology, v.17, n.1, p.19-32, Sept. 1999. 
HONG, S.; KIM, D. Influence of oxygen concentration and temperature on respiratory characteristics of fresh-cut green onion. International Journal of Food Science and Technology, v.36, n.3, p.283-289, Mar. 2001.

HOWARD, L.R.; GRIFFIN, L.E. Lignin formation and surface discoloration of minimally processed carrot sticks. Journal of Food Science, v.58, n.5, p.10651067, 1072, 1993.

HOWARD, L.R.; GRIFFIN, L.E.; LEE, Y. Steam treatment of minimally processed carrot sticks to control surface discoloration. Journal of Food Science, v.59, n.2, 1994.

HUSSEIN, A.; ODUMERU, J.A.; AYANBADEJO, T.; FAULKNER, H.; MCNAB, W.B.; HAGER, H.; SZIJARTO, L. Effects of processing and packaging on vitamin $\mathrm{C}$ and $\beta$-carotene content of ready-to-use (RTU) vegetables. Food Research International, v.33, n.2, p.131-136, 2000.

IZUMI, H.; WATADA, A.E.; DOUGLAS, W. Low oxygen atmospheres affect storage quality of zucchini squash slices treated with calcium. Journal of Food Science, v.61, n.2, p.317-321, 1996.

KADER, A.A. Biochemical and physiological basis for effects of controlled and modified atmospheres on fruits and vegetables. Food Technology, v.40, n.5, p.99104, May 1986.

KADER, A.A. Modified atmospheres during transport and storage. In: KADER, A.A. (Ed.). Postharvest technology of horticultural crops. Oakland, California: Division of Agriculture and Natural Resources - University of California, 1992. cap.11, p.85-92. 
KADER, A.A.; WATKINS, C.B. Modified atmosphere packaging - toward 2000 and beyond. HortTechnology, v.10, n.3, p.483-486, July-Sept. 2000.

KADER, A.A.; ZAGORY, D.; KERBEL, E.L. Modified atmosphere packaging of fruits and vegetables. CRC Critical Reviews in Food Science and Nutrition, v.28, n.1, p.1-30, 1989.

KASMIRE, R.F.; CANTWELL, M. Postharvest handling systems: flower, leafy, and stem vegetables. In: KADER, A.A. (Ed.) Postharvest technology of horticultural crops. Oakland, California: University of California, 1992a. cap.30, p.267-270.

KASMIRE, R.F; CANTWELL, M. Postharvest handling systems: underground vegetables (roots, tubers, and bulbs). In: KADER, A.A. (Ed.) Postharvest technology of horticultural crops. Oakland, California: University of California, 1992b. cap.31, p.271-275.

KAYS, S.J. Postharvest physiology of perishable plant products. New York: Van Nostrand Reinhold, 1991. cap.6, p.335-407: Stress in harvested products.

KE, D.; SALTVEIT, M.E. Wound-induced ethylene production, phenolic metabolism and susceptibility to russet spotting in iceberg lettuce. Physiologia Plantarum, v.76, n.2, p.412-418, 1989

KIDD, F.; WEST, C.; BRIGGS, G.E.A. A quantitative analysis of the growth of Helianthus annuus. Part I. The respiration of the plant and of its parts throughout the life cycle. Royal Society London Proceedings, B92, p.368-384, 1921.

KIM, B. S.; KLIEBER, A. Quality maintenance of minimally processed Chinese cabbage with low temperature and citric acid dip. Journal of Science of Food and Agriculture, v.75, n.1, p.31-36, Sept. 1997. 
KIM, B-S; KLIEBER, A. Freshness prolongation of minimally processed chinese cabbage with active modified atmosphere packaging. Acta Horticulturae, v. 483, p.319-324, 1999.

KING JUNIOR, A.D.; BOLIN, H.R. Physiological and microbiological storage stability of minimally processed fruits and vegetables. Food Technology, v.43, n.2, p.132135, 139, Feb. 1989.

KLIEBER, A; FRANKLIN, B. Ascorbic acid content of minimally processed chinese cabbage. Acta Horticulturae, v.518, p. 201-204, Mar 2000.

KUBO, Y.; INABA,A.; NAKAMURA, R. Respiration rate and $\mathrm{C}_{2} \mathrm{H}_{4}$ production in various harvested crops held in $\mathrm{CO}_{2}$-enriched atmospheres. Journal of the American Society for Horticultural Science, v.115, n.6, p.975-978, 1990.

LEE, S.K.; KADER, A.A. Preharvest and postharvest factors influencing vitamin C content of horticultural crops. Postharvest Biology and Technology, v.20, n.3, p.207-220, Nov. 2000.

LIOUTAS, T.S. Challenges of controlled and modified atmosphere packaging. Food Technology, v.42, n.9, p.78-82, 1988.

LÓPEZ-GÁLVEZ， G.; SALTVEIT, M.; CANTWELL， M. Wound-induced phenylalanine ammonia lyase activity: factors affecting its induction and correlation with the quality of minimally processed lettuces. Postharvest Biology and Technology, v.9, n.2 ,p.223-233, Nov. 1996.

LUENGO, R.F.A.; LANA, M.M. Processamento mínimo de hortaliças. Brasília: EMBRAPA, 1997. 4p. (EMBRAPA. Comunicado Técnico, 2). 
MERTENS, H.; TRANGGONO. Ethylene and respiratory metabolism of cauliflower (Brassica oleracea L. convar. Botrytis) in controlled atmosphere storage. Acta Horticulturae, v.258, p.493-501, 1989.

MITCHELl, F.G.; GUILlOU, R.; PARSONS, R.A. Commercial cooling of fruits and vegetables. Berkley, California: Division of Agricultural Sciences, University of California, 1972, 44p.

MURR, D.P; MORRIS, L.L. Influence of $\mathrm{O}_{2}$ and $\mathrm{CO}_{2}$ on o-diphenol oxidase activity in mushrooms. Journal of the American Society for Horticultural Science, v.99, n.2, p.155-158, Mar. 1974.

NGUYEN-THE, C.; CARLIN, F. The microbiology of minimally processed fresh fruits and vegetables. Critical Reviews in Food Science and Nutrition, v.34, n.4, p.371401, 1994.

O'BEIRNE, D.; BALLANTYNE, A. Some effects of modified-atmosphere packaging and vaccum packaging in combination with antioxidants on quality and storage life of chilled potato strips. International Journal of Food Science and Technology, v.22, n.5, p.515-523, Oct. 1987.

OHLSSON, T. Minimal processing - preservation methods of the future: an overview. Trends in Food Science and Technology, v.5, n.11, p.341-344, 1994.

OLIVEIRA, F.A.R.; FONSECA, S.C.; OLIVEIRA, J.C.; BRECHT, J.K.; CHAU, K.V. Development of perforation-mediated modified atmosphere packaging to preserve fresh fruit and vegetable quality after harvest. Food Science and Technology International, v.4, n.5, p.339-352, Oct. 1998. 
OSORNIO, M.M.L.; CHAVES, A.R. Quality changes in stored raw grated beetroots as affected by temperature and packaging film. Journal of Food Science, v.63, n.2, p.327-330, Mar.-Apr. 1998.

PEIRIS, K.H.S.; MALLON, J.L.; KAYS, S.J. Respiratory rate and vital heat of some specialty vegetables at various storage temperatures. HortTechnology, v.7, n.1, p.46-49, Jan-Mar, 1997.

PIERGIOVANNI, L.; FAVA, P.; CERIANI, S. A simplified procedure to determine the respiration rate of minimally processed vegetables in flexible permeable packaging. Italian Journal of Food Science, v.11, n.2, p.99-110, 1999.

PIROVANI, M. E.; GÜEMES, D. R.; PIAGENTINI, A. M.; DI PENTIMA, J. H. Storage quality of minimally processed cabbage packaged in plastic films. Journal of Food Quality, v.20, n.5, p.381-389, Nov. 1997.

PRINCE, T. A. Modified atmosphere packaging of horticultural commodities. In: BRODY, A.L. (Ed) Controlled/modified atmosphere/vacuum packaging of foods, Trumbull, Connecticut: Food \& Nutrition, 1989, cap.5, p.67-100.

RATTI, C.; RAGHAVAN, G.S.V.; GARIÉPY, Y. Respiration rate model and modified atmosphere packaging of fresh cauliflower. Journal of Food Engineering, v. 28, n.3/4, p.297-306, 1996.

REID, M.S. Ethylene in postharvest technology. In: KADER, A.A. (Ed.) Postharvest technology of horticultural crops. Oakland: California: University of California, 1992. cap.13, p.97-108.

REYS, V.G. Improved preservation systems for minimally processed vegetables. Food Australia, v.48, n.2, p.87-90, 1996. 
ROCHA, A.M.C.N.; BROCHADO, C.M.; KIRBY, R.; MORAIS, A.M.M.B. Shelf-life of chilled cut orange determined by sensory quality. Food Control, v.6, n.6, p.317322, Dec. 1995.

ROLLE, R.S.; CHISM, G.W. Physiological consequences of minimally processed fruits and vegetables. Journal of Food Quality, v.10, n.3, p.157-167, 1987.

ROSEN, J.; KADER, A.A. Postharvest physiology and quality maintenance os sliced pear and strawberry fruits. Journal of Food Science, v.54, n.3, p.656-659, May 1989.

ROURA, S.I.; DAVIDOVICH, L.A.; DEL VALLE, C.E. Postharvest changes in fresh swiss chard (Beta vulgaris, type cycla) under different storage conditions. Journal of Food Quality, v.23, n.2, p.137-147, May 2000a.

ROURA, S.I.; DAVIDOVICH, L.A.; DEL VALLE, C.E. Quality loss in minimally processed swiss chard related to amount of damaged area. Lebensm-Wiss und Technolology, v.33, n.1, p.53-59, 2000b.

RYALL, A.L.; LIPTON, W.J. Handling, transportation, and storage of fruits and vegetables: Vegetables and melons.. Westport: The AVI, 1972. v.1, cap.16, p.303350: Market disorders of leafy vegetables and immature flower heads.

SALUNKE, D.K.; BOLIN, H.R.; REDDY, N.R. Storage, processing, and nutritional quality of fruits and vegetables: Fresh fruits and vegetables. Boca Raton, Florida: CRC Press, 1991. v.1, cap.3, p.45-64: Postharvest physiology.

SAPERS, G.M.; MILlER, R.L.; MILlER, F.C.; COOKE, P.H.; CHOI, S.W. Enzymatic browning control in minimally processed mushrooms. Journal of Food Science, v.59, n.5, p.1042-1047, 1994. 
SAS INSTITUTE, INC, The SAS System for Windows - Release 6,11, Cary, NC, 1996. (CD).

SCHLIMME, D.V. Marketing lightly processed fruits and vegetables. HortScience, v.30, n.1, p.15-17, Feb. 1995.

SILVA, N.; JUNQUEIRA, V.C.A.; SILVEIRA, N.F.A. Manual de métodos de análise microbiológica de alimentos. 2.ed. Sao Paulo: Livraria Varela, 2001. 317p.

SMYTH, A.B.; SONG, J.; CAMERON, A.C. Modified atmosphere packaged cut Iceberg lettuce: effect of temperature and $\mathrm{O}_{2}$ partial pressure on respiration and quality. Journal of Agricultural and Food Chemistry, v.46, n.11, p.4556-4562, Nov. 1998.

SOUCI, S.W.; FACHMANN, W.; KRAUT, H. Food composition and nutrition tables. 6.ed. Stuttgart: Medpharm Scientific, 2000. p.694: Cauliflower.

TATSUMI, Y.; WATADA, A.E.; WERGIN, W.P. Scanning electron microscopy of carrot stick surface to determine cause of white translucent appearance. Journal of Food Science, v.56, n.5, p.1357-1364, 1991.

TAVARES, S.A; SANTOS, F.F.; MATOS, M.J.L.F.; MELO, M.F; LANA, M.M. Hortaliças: rúcula. Correio Brasiliense., Brasília, DF, 12 fev. 2000a. 3p. (Encarte Especial).

TAVARES, S.A; SANTOS, F.F.; MATOS, M.J.L.F.; MELO, M.F; LANA, M.M. Hortaliças: couve-flor. Correio Brasiliense. Brasília, DF, 19 fev. 2000b. 3p. (Encarte Especial). 
TELES, C.S. Avaliação física, química e sensorial de couve (Brassica oleracea, L. var. acephala) minimamente processada, armazenada sob atmosfera modificada. Viçosa, 2001. 102p. Tese (Doutorado) - Universidade Federal de Viçosa.

TIAN, M.S.; DOWNS, C.G.; LILL, R.E.; KING, G.A. A role for ethylene in the yellowing of broccoli after harvest. Journal of the American Society for Horticultural Science, v.119, n.2, p.276-281, 1994.

TOIVONEN, P.M.A. The effects of storage temperature, storage duration, hydrocooling, and micro-perforated wrap on shelf life of broccoli (Brassica oleracea L., Italica Group). Postharvest Biology and technology, v. 10, n.1, p.59-65, Jan. 1997.

TRANI, P.E.; PASSOS, F.A. Rúcula (Pinchão). In: FAHL, J.I.; CAMARGO, M.B.P. de; PIZINATTO, M.A.; BETTI, J.A.; MELO, A.M.T.de; DEMARIA, I.C.; FRURLANI, A.M.C. (Ed.) Instruções agrícolas para as principais culturas econômicas. Campinas: IAC, 1998. p.241-242. (IAC. Boletim, 200).

VALLESPIR, A.N. Post-recoleccion de hortalizas: Vol. I - Hortaliza de hoja, tallo y flor. Reus, España: Ediciones de Horticultura, S.L., 1993a. cap.19, p.299-315: Coliflor.

VALLESPIR, A.N. Post-recoleccion de hortalizas: Vol. I - Hortaliza de hoja, tallo y flor. Reus, España: Ediciones de Horticultura, S.L., 1993b. cap.14, p.209-224: Otras hortalizas de hoja.

VAROQUAUX, P.; WILEY, R.C. Biological and biochemical changes in minimally processed refrigerated fruits and vegetables. In: WILEY, R.C. (Ed.) Minimally processed refrigerated fruits \& vegetables. New York: Chapman and Hall, 1994. cap. 6, p.226-268. 
WATADA, A.E.; KAZUHIRO, A.; YAMUCHI, N. Physiological activities of partially processed fruits and vegetables. Food Technology, v.44, n. 5, p.116-122, May 1990.

WATADA, A.E.; KO, N.P.; MINOTT, D.A. Factors affecting quality of fresh-cut horticultural products. Postharvest Biology and Technology, v.9, n.2, p.115-125, Nov. 1996.

WATADA, A.E; QI, L. Quality control of minimally-processed vegetables. Acta Horticulturae, v. 483, p.209-219, 1999.

WEICHMANN, J. The effect of controlled-atmosphere storage on the sensory and nutritional quality of fruits and vegetables. Horticultural Reviews, v.8, p.101-127, 1986.

WILEY, R. C. Minimally processed refrigerated fruits and vegetables. New York, NY: Chapman \& Hall, 1994. 368p.

WRIGHT, K.M.; KADER, A.A. Effect of slicing and controlled-atmosphere storage on the ascorbate content and quality of strawberries and persimmons. Postharvest Biology and Technology, v.10, n.1, p.39-48, Jan. 1997

ZHUANG, H.K.Y.; BARTH, M.M.; HILDEBRAND, D.F. Packaging influenced total chlorophyll, soluble protein, fatty acid composition and lypoxygenase activity in broccoli florets. Journal of Food Science, v.59, n.6, p.1171-1174, Nov./Dec. 1994. 